\title{
The Rule of Law in the Athenian Dêmokratia: Origins, History, and Oratory
}

Bede Laracy

A Thesis Submitted to the Victoria University of Wellington in Fulfilment of the Requirements for the Degree of Master of Arts in Classical Studies

Victoria University of Wellington

2008 


\section{Acknowledgements}

Having followed a deliberate path of studying a wide range of topics while at university, I recognise that Classics resonates through almost every aspect of academia. I also recognise the benefit of two important influences on my education. First, "fortune" has delivered me to the right places and people, and at the right time. Second, my determination to recognise opportunities and persist has allowed me to pursue opportunities when they arose.

I would like to thank the staff, both academic and administrative, at the VUW Classics Department for making opportunities available for me to pursue, and for allowing me to pursue them. In particular, Dr David Rosenbloom, my supervisor, has been a source of huge support and learning. Any persistent problems within this thesis are not through lack of trying on his part. It has been both an honour and a privilege to have his guidance through my postgraduate years. In addition, Dr Matthew Trundle throughout the years has consistently been supportive of me both as a student and as a person.

I would also like to thank my friends and family, especially Trina, for all the support throughout my education, in as much as it is complete.

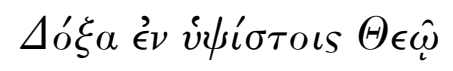




\begin{abstract}
According to Aristotle, dêmokratia is an invalid form of constitution unless it operates in conjunction with the rule of law. Historically, the idea of the rule of law was connected with wealthy elites in Athens. However, after a series of upheavals between the Athenian mass and elites, the dêmos accepted the rule of law as a valid check on demotic power. Rule of law required legal codification, which outlined a framework within which democratic law functioned. The Athenian law court became the arena for enforcing the law, thereby ridding the city of negative socio/political influences. Hybris, political corruption, and general questions of legality all came under the power of the democratic courts of law, which exerted the legitimate power of the combined community.
\end{abstract}

Nevertheless, tradition maintained a strong influence on law, especially in the law courts. Bound up in legal arguments were ideas of Athenian identity and it became accepted that the juries would assess the character of the accused against the character of the Athenian dêmos in the course of making its decision. Athenian elites who previously continued feuds extra-legally submitted to the law courts, which offered an arena for dispute resolution. Ultimately, the rule of law in the Athenian dêmokratia upheld Athenian law, created a legal framework, and allowed personal and political disputes to be settled before they dissolved into stasis, offering the Athenian dêmokratia its most successful mechanism for creating social, political, and legal, stability. 


\section{Contents}

Introduction

PART 1: ATHENIAN DÊMOKRATIA AND THE RULE OF LAW

Chapter 1: Law in the Athenian Constitution: Thesmoi,

Nomoi, \& Psêphismata

Chapter 2: Dêmokratia and the Emergence of the

Rule of Law

Chapter 3: The Rule of Law in the Fourth-Century

Dikastêria

PART 2: CASE STUDIES

Chapter 4: Law and the Character of the Dêmos:

Demosthenes 20, Against Leptines

Chapter 5: Hybris and the Rule of Law:

Demosthenes 21, Against Meidias

Chapter 6: Euthynai: Rule of Law and the Sovereignty of the Dikastêria - Demosthenes 19/Aeschines 2

Conclusion

Bibliography 
Humanity does not gradually progress from combat to combat until it arrives at universal reciprocity, where the rule of law finally replaces warfare; humanity installs each of its violences in a system of rules and thus proceeds from domination to domination.

\section{Michel Foucault}




\section{Introduction}

To describe a society's constitution as a democracy, or dêmokratia, implies a sense that the people who live in it have a degree of power over the key decisions made within it. In Athens in the Classical era, Athenian citizens asserted their full combined power to take control of all the city's affairs, and the polis ran under the banner of demokratia. The combined Athenian male citizenry, the dêmos, wielded power over the making and administration of laws, the distribution of official powers, economic structure, and external relations. Key to the idea of demokratia were principles such as isonomia, isêgoria, and eleutheria, which meant that citizens could freely pursue a political life and contribute positively into the politics of the state. ${ }^{1}$ A large politically motivated state required a sound legal structure. Solon created the graphê, which gave all citizens the ability to make use of the law courts and assist in protecting the community. However, official power remained open only to the wealthier citizens. Cleisthenes reformed the constitution under the principle of isonomia, which asserted the idea of political equality for all citizens. However, the Areopagus maintained a degree of control over judicial functions. When Ephialtes stripped the Areopagus of its accrued political powers, the polis of Athens became truly democratic, as the dêmos then held power over all aspects of the polis' affairs. Henceforth, powerful leaders had to conform to the expectations and interests of the demos to gain its following. Two key elements then emerged. First, those who desired power had to

\footnotetext{
${ }^{1}$ On isonomia see 19-20, 37-9; isegoria 34; eleutheria 20-1.
} 
compete for it, and the competition was open to all citizens. Second, what constituted law changed. In early Athens, laws such as the codes of Draco and Solon were thesmoi, laid down by a lawgiver and based on traditional religious concepts of morality. However, after the emergence of dêmokratia, nomos became the standard of law, passed by the dêmos in the ekklêsia, and administered through the dikasteria. With no formal separation of powers, the dêmos had full legal control of the polis, a position that Ostwald defends strongly.

Chapter 1 discusses the various key types of law from the end of the archaic age throughout the democratic era. The development of the polis saw the desire for written law, which originally took the form of thesmoi. Imposed by a constitutionally elected leader, thesmoi adopted old religious ideals of reward and punishment at the hands of the gods for their basis. A good citizen was one who obeyed such laws, and the bad one disobeyed, bringing destruction to themselves, their oikos, and sometimes their polis. There was, however, no explicit state sanction for disobedience to thesmoi. Instead, the graphê began to establish a legal framework that citizens could use to offer the community protection from miscreants. Thesmoi were therefore laws that had a moral and normative basis, and may have a supporting legal action connected with them.

With the development of demokratia at the end of the sixth century, the dêmos became the key law-making body, and nomoi and psêphismata emerged as the key forms of law. During the fifth century, no formal distinction existed 
between them. Both were authoritative as sources of law, and the disobedience of both could lead directly to lawful punishment. As an expression of the collective interest of the dêmos, nomoi and psêphismata could be enacted without strict regard either to previous law or to tradition. Hence, when such interests began to override sectors of the community, the position became politically untenable. In a bid to hold the law-making process to account, Athenian elites began calling for the codification of the Athenian law, and demanded that such a code be based on the patrios politeia and the patrioi nomoi. In effect, those offering the proposal were attempting to establish legal principles to guide the law-making processes rather than allow the dêmos to act as a tyrant by enacting according to its whim.

After the oligarchic revolutions of the fifth century and the restoration of demokratia, codified Athenian law became a reality. The process had taken approximately ten years, as the decrees of Patrokleides and Teisamenos show (And. 1.77-89). Procedures were formalised for the creation of nomoi, nomoi were to have force over other laws, including psêphismata, and the jury oath demanded that jurors decide according only to nomoi. The platform was then set for the rule of law, which had become a desire of oligarchic revolutionaries, to emerge as a live political and legal topos. However, nomoi meant not only law, but also custom, and no separation between the two occurred. The customary sense of nomos continued alongside the more positivist legal sense. Consequently, unwritten law continued to have some force within the legal system at Athens. 
Chapter 2 looks at Athenian dêmokratia and the emergence of the rule of law. The key event for the beginning of demokratia is the revolution from tyranny at the end of the sixth century, followed by the reforms of Cleisthenes. The revolution taught the dêmos that it could overpower constitutionally elected leaders simply through the force of numbers. As Ober and Johnstone argue, the dêmos became a self-defined body through the process of revolution. However, only with the removal of the Areopagus' accrued powers under the reforms of Ephialtes did dêmokratia fully emerge. The dêmos then had the necessary and sufficient control over its own affairs to become truly democratic. Nevertheless, leaders such as Pericles continued to derive from traditional leading families, creating a useful dialogue between mass and elite. After the death of Pericles, a new breed of politician emerged who took the Cleisthenic route of ignoring political cliques and appealing directly to the desires of the dêmos in a much more explicit fashion.

The end of the fifth century saw an increase in the political dialogue around the interests of the dêmos, culminating in tyranny under the numerical majority of the dêmos. With the force of numbers the dêmos could, and on occasions did, use its law-making powers according to its whim and to the detriment of sectors within its own community. In the trial of the generals following the battle at Arginusae, the self-interested force of demokratia found its ultimate end. Revolution that required the complete disestablishment of the democratic constitution became a necessity for those with sufficient resources and connections. Once achieved, the call to arms fell around the establishment 
of written law according to tradition. The aim was to overrule the dêmokratia, but the effect was ultimately to create the basis for a system of checks and balances on the otherwise unrestrained law-making power of the dêmos. However, oligarchy too declined into tyranny under Critias, destroying its credibility. The increase in power that the dikasteria achieved throughout the fifth century came under question with the disestablishment of the dêmokratia, only to re-emerge even more securely under the constitutional reforms beginning with the democratic restoration and the codification of Athenian law.

Chapter 3 takes a detailed look at Athenian oratory, particularly speeches made in the fourth-century dikastêria. The rule of law established after the restoration of dêmokratia clarified the jurisdiction and increased the activity of the Athenian dikasteria. Courts became, as Cohen strongly contends, the legitimate arena both for legal disputes, and for those of a more personal or political nature. The rule of law demanded a positivist approach to law on a simple reading. However, the very nature of what constituted nomos allowed non-legal matters to be addressed. The continuation of unwritten law in legal disputes had two key supports. First, the codification of Athenian law occurred under the guidance of the patrios politeia and the patrioi nomoi. What was patrios was traditional, and the laws of Solon became the touchstone for the validity of laws. Hence, a litigant in the dikastêria would try to show a correlation between democratic Athenian law, as they perceived it, and the laws of Solon. Thus, thesmoi retained some relevance in the fourth 
century dêmokratia. The litigant in the dikastêria became the de facto legal theorist.

The second support for unwritten law was in the continued connection between nomos and custom. Under the rule of law, a nomos was a law made according to proper procedure. However, nomos continued to refer to custom, at least in the minds of Athenian citizens. Hence, when asked to decide according to Athenian nomoi, a juror may legitimately draw on his understanding of Athenian custom. Even clearer, however, is the way orators explicitly referred to Athenian custom in their speeches. As traditional laws drew on Solonian law, so too did traditional custom draw on Solonian custom. In both cases, what was Solonian was a nebulous concept. Litigants would therefore draw on the idea of the Athenian chrêstoi and ponêroi, showing themselves as a good citizen (chrêstos), while the opponent was the paradigm bad citizen (ponêros). Evidence would lie in their obedience, or disobedience, to the traditional moral order in which the good were rewarded and the bad punished. A ponêros citizen could bring atê, destruction, upon the polis. It was therefore up to the dikastêria to punish the miscreant severely. In doing so, the dikastêrion adjudicates on the timê, honour, of each of the litigants and takes on the moral authority of the Areopagus, which had played a traditional role as nomophulax, the guardian of the laws. Consequently, the dikasteria became not only the legitimate decider of legal fact, but also the legitimate arena for intra-polis disputes. In doing so, the dikastêria under the rule of law became the balancing factor in the polis, offering lasting stability to the dêmokratia. 
The focal point of Chapter 4, Demosthenes' Against Leptines, is a graphê nomon mê epitêdeion theinai, the companion of the graphê paranomôn, against the proposer of a law that tries to revoke the dêmos' power to grant ateleia, the exemption from certain duties. A graphê nomon mê epitêdeion theinai allows a citizen to prosecute the proposer of a nomos that conflicts with an existing nomos, while the graphe paranomôn applies in the same way to psêphismata. Demosthenes initially shows that the proposal directly conflicts with an existing nomos, then attempts to show that the nomos conflicts with Athenian tradition. As a result, Leptines' law not only dishonours Athens by isolating it from its glorious past, but also removes the ability for the dêmos to make certain decisions in the future, thereby limiting its powers. The question then is whether the law upholds or subverts Athenian interests.

Demosthenes' aims appear democratic, in that he seeks to keep the decision making power within the sphere of the ekklêsia and the dikastêria. However, the ideals to which Demosthenes refers are consistently those that come from the elite tradition in Athens. His arguments support the strength of custom over law, of the old over the new, and of honour over money. Consequently, Demosthenes proves himself an inheritor of the Periclean tradition with its links to aristocracy and reliance on ancient ideals such as charis, and he draws heavily on an imagined community of Athenian tradition. While pursuing a valid legal action, Demosthenes also establishes a set of extra-legal social and moral norms for the polis. 
Chapter 5 analyses Demosthenes' Against Meidias, in which

Demosthenes issues proceedings against Meidias after an assault. Such a case could straightforwardly turn on a question of fact. However, Demosthenes and Meidias had a long-standing personal enmity, and the assault occurred publicly while Demosthenes was performing a liturgy, acting as the chorêgos of his tribe's dithyrambic chorus. Demosthenes depicts himself as a victim who seeks shelter in Athenian nomos, while portraying Meidias as a hybristês who seeks to gain undue power within the polis. As a hybristês, Meidias approaches tyranny, putting the dêmokratia and its underlying principles of isonomia, isêgoria, and eleuthêria, at risk. In threatening the rule of law, Meidias disregards the interests of the dêmos, and makes himself an enemy of dêmokratia. Further, his over-inflated sense of self is an indication of tyrannical aspiration. Demosthenes uses the legal action of probolê to argue his theory of, and Meidias' conflict with, Athenian dêmokratia.

Chapter 6 looks at the cases Demosthenes 19/Aeschines 2, in which there are also overt examples of personal enmity. Demosthenes uses the process of euthyna to expose Aeschines as a traitor who took bribes from Philip for personal gain and caused detriment to the polis and its allies. Aeschines, on the other hand, attempts to show that not only did he not take such bribes, but also that he is not the type of person that would take bribes. Both use their ideas of the good Athenian to show that they conform to it, while their opponent conflicts with it. Aeschines, as the accused, is forced to explore notions of the chrêstos citizen more deeply to defend his position. 
Demosthenes tries to interpret a bribe broadly to catch Aeschines within the law, and proceeds to abuse him with severity. Aeschines takes refuge in the dikastêria, supplicating according to dramatic tradition and upholding the dikastêria as nomophulax. Demosthenes uses the legal process of euthyna to hold Aeschines accountable according to Athenian law and in the process pursues a personal enemy to gain political dominance within Athens. Aeschines acts to defend his character and return to political life at Athens, and in the process also try to discredit a personal and political enemy.

All three cases are examples of a citizen using the dikastêria to pursue a legal case according to Athenian nomoi. Doing so promotes and protects the legal process and upholds the rule of law. Such a position does not require a litigant to argue overtly according to the rule of law. Rather, the rule of law, in its broader sense, is upheld simply by using the legal mechanisms to promote due process. However, all three cases evolve from arguing the simple legal issues to arguing issues of a more personal nature. The arguments follow common topoi in a bid to highlight aspects of character that promote the speaker while demoting the opponent. Personal enmity consequently played a strong and important role in the legal processes within the dikasterria. Nevertheless, personal enmity cannot be said to be the only, or even necessarily the main, motivation of a case. It does, however, direct the enquiry into the Athenian legal system down the path of analysing the place of unwritten law in what at some levels professes to be a positivist legal system. While positive law created a framework for the Athenian legal system, within 
that framework lay a network of social, political, and moral avenues that a litigant could, and frequently did, use to win a case. Consequently, the rule of law in the Athenian dêmokratia provided a framework for the legitimate place and use of the dikastêria in legal disputes, and offered an avenue within which personal and political disputes could be settled. The effect, therefore, was that the rule of law in fourth-century Athens acted as a balancing factor in a society that had shown its ability to decline into either tyranny or stasis, and sometimes both. 


\section{Chapter 1}

\section{Law in the Athenian Constitution: Thesmoi, Nomoi, \& Psêphismata}

Law can take a number of forms. In very early societies, law tended to be the realm of the king and his powerful supporters, and imbued with a sense of divine ordinance. Societies that were more complex required complex legal mechanisms, and with the growth of the Greek polis grew the desire to adopt written laws. In Athens, Draco and Solon began the writing process, providing basic legal codes that took the form of thesmoi, which were themselves based on long held traditional socio-religious norms. Solon also established a strong judicial mechanism to administer the laws, working on the principle of good government, or eunomia. By the time of Cleisthenes, many Athenians had adopted a sense of political equality that forced a change toward isonomia as an overarching political principle. Laws were then made by all, for the benefit of all, and for all to obey and uphold. Hence, the beginning of dêmokratia was predicated on political equality and accountability to known laws. Fundamental to the process is the development of the law from thesmoi to nomoi and psepphismata. Where leaders drew on socio/religious norms in imposing thesmoi, laws later came about through a process of discourse. Athenian nomoi therefore became synonymous with dêmokratia. As written law grew in force, and accountability became more common, the rule of law emerged as a way to ensure consistency in the creation and administration of laws. Based on a version of the patrios politeia, codification in the late fifth 
century provided the basis for the constitutional rule of law, and further legitimised elite Athenians' use of democratic principles to promote their own purposes. However, codified law and newly established procedures also became a way for the dêmokratia to ensure individual citizens could not subvert the dêmokratia and exercise excessive power. Polis life in Athens led to the ideal of citizenship based on political ties, and law became the voice through which the combined citizen body spoke. Dêmokratia under the rule of law required the dikasterria to decide on the correct application of a law. There remained a tension between the idea of law as decided by the community together, and law as imposed by certain political and legal institutions. Consequently, the development of Athenian nomos proceeded in tandem with the development toward dêmokratia and its reliance on isonomia, and the rule of law became a vehicle for obtaining certainty and accountability in the pursuit for eunomia.

One of the key functions of law is to create a sense of certainty in terms of what is and is not acceptable behaviour. In a primitive society, disputes taken to a king or judge fell to the discretion of the decision maker, which may or may not be tempered by current ideas in the community. ${ }^{2}$ Established law and legal procedures achieve two purposes in relation to certainty. First, it enables citizens to order their affairs and conduct. Second, it enables citizens to maintain a degree of control over their decision makers. A further function of law is to direct citizens to the correct institutions and procedures to which

\footnotetext{
${ }^{2}$ MacDowell (1978): 41.
} 
they should take their disputes. Written and publicly displayed laws supported by rigorous legal institutions became the valid way to achieve sufficient certainty, thereby relieving the polis from public outbreaks of private and personal disputes. ${ }^{3}$ Draco's code in $621 / 20$ BC was the first form of written law in Athens. ${ }^{4}$ Solon, in 594 BC, established a new legal code, which he published on axones and kyrbeis, though he kept Draco's homicide laws (Ath. Pol. 7.1). ${ }^{5}$ These became the laws of Athens, and the basis of the patrios politeia. Jurors in the courts then had to make decisions of guilt or innocence according to the facts as against the relevant law or decree. ${ }^{6}$ However, the jury's decision was based on the law according to the particular litigants involved in the case, and it was up to the litigants to establish what law, or kind of law, would come into play. To understand the impetus behind particular legal arguments therefore requires an understanding of the key types of law litigants may draw on, being thesmoi, nomoi, and psêphismata.

A thesmos is a "thing laid down". The term first appears in Homer, where the marriage bed of Penelope and Odysseus is referred to as "lektroio palaiou thesmos" (Odyssey 23.269), and refers to "a thing placed in a specific location". A Aeschylus calls the institution of the Areopagus a thesmos (Eu. 615,681 ), and refers to the thesmos by which Athene established the Areopagus (Eu. 370-73). The Athenian Ephebic oath demands obedience to

\footnotetext{
${ }^{3}$ See Lys. 1.33-6.

${ }^{4}$ MacDowell (1978): 42.

${ }^{5}$ Ostwald (1969): 15-6; on axones and kyrbeis see Holland (1941); Stroud (1979).

${ }^{6}$ MacDowell (1978): 44.

${ }^{7}$ Ostwald (1969): 12.
} 
thesmoi whether already or yet to be established. ${ }^{8}$ Sophocles uses thesmos to refer to a verbal command (Trach. 680-4). Teucer refers to the fact that there is no thesmos giving Menelaus authority over Ajax (Soph. Ajax, 1104). Use of the term thesmoi in the fourth century appears somewhat anachronistic, but Andocides refers to the thesmoi of Draco $(1.81,83)$, Demosthenes cites a nomos that refers to itself as a thesmos (23.62), and Aeschines mentions that the Thirty ruled in Athens under "unjust thesmoi" (3.190). While thesmoi frequently appear in written form, writing is not an essential part of a valid thesmos. ${ }^{9}$ In each of the cases, however, an external agent imposes the thesmos and the imposition implies a duty on the lesser party to obey extra-legal norms according to nature, the gods, or tradition. ${ }^{10}$ The party that has a thesmos imposed on them will likely have little or no input into what shape the thesmos takes. Thesmoi symbolise long-standing traditional concepts of justice, and represent a kind of higher moral order to Athenian law. ${ }^{11}$ In establishing the thesmothetai at the end of the fifth century, there is an implication that Athens was acknowledging thesmoi, but giving itself a way to reclaim it as a democratic institution.

Nomos implies an accepted norm. Hesiod uses nomos in describing the 'order of living' by which men live according to Zeus' scheme ( $W \& D$ 276-80),

\footnotetext{
${ }^{8}$ Ostwald (1969): 14.

${ }^{9}$ Ostwald (1969): 17.

${ }^{10}$ Ostwald (1969): 18-9; 55; MacDowell (1978): 44; note that the broad differentia between thesmoi here and democratic nomoi is that an external agent does not make the nomoi, and the obligations to obey thesmoi are generally external, i.e. customary or religious, whereas the obligations to obey a nomos are socio/political, and contained within the law itself.

${ }^{11}$ See, for example, Aeschylus, Eumenides, 389-97, 482-84, 570-73; Euripides, Fragments, 360.45, 16.15-21; Medea, 492-96; Trachiniae, 266-68; Sophocles, Ajax, 710-14; Antigone, 799-805.
} 
and uses "nomos of the plains" to describe the proper way of going about farming ( $W \& D$ 388). Hippocrates (On Airs, Waters, and Places, 16, 23, 24) states that "nomos can implant courage and endurance in the souls of dwellers in valleys where physis has not done so."12 Euripides speaks of written laws as the bulwark against tyranny (Su. 433), while elsewhere (fr. 597) he asserts the value of a good character as superior to that of law, effectively showing support for the force of physis over nomos. Antigone tells Creon that Zeus has not given him the kind of nomos to be able to deny her burying her brother (Soph. Ant. 450-2), highlighting the importance of strongly held customs even in the face of a tyrant's edict. However, Ismene refuses to join Antigone, as "it would be a violation of nomos to defy the tyrant's decree" (Soph. Ant. 59). While nomoi were accepted norms, whether written or unwritten, there was debate on the particular application and the force of one as against the other. Nomoi could cover a large range of norms, from simple instructions to broad legal principles.

The use of nomos to describe a custom does not come into its own until the second half of the fifth century, particularly with Herodotus (3.31.4; 3.38.4) and Pindar (fr. 169a) who place nomos as the "king of all" (nomos panton basilea). In Herodotus, the Plataeans refer to the nomos established for all men which permits defence against enemy attacks (3.56.2), and the Thebans admit that it is 'in accordance with some sort of nomos' to kill one's opponent in battle, but they protest that it was in violation of nomos

\footnotetext{
${ }^{12}$ Ostwald (1969): 22; on nomos/physis see 27-30.
} 
(paranomos) to slaughter prisoners of war (3.66.2) ${ }^{13}$ The speakers draw on widely held Hellenic customs, showing the existence of common nomoi between states. However, when Darius asks Greeks and Indians to perform each other's burial customs on their own dead, each refuses in disgust (Hdt. 3.38). Nomoi could also be, and more frequently were, different between states. Differing customs ensured that laws developed differently according to the local understanding of the world. Hence, what a nomos was became a subject of political debate.

Initially, nomos could refer to written or unwritten legislation. The more important feature for the Athenians was who regarded themselves as bound by particular nomoi. ${ }^{14}$ Although the Antigone turns on the question of whether Antigone should follow an edict and ignore a nomos, the impact of the tragedy would lessen without an implicit general acceptance of Creon's edict. ${ }^{15}$ Agamemnon in the Ajax highlights the importance of consent by showing that if everyone, like Ajax, refused to obey the law or legal mechanisms, then no nomoi could stand (Ajax 1247). Sophocles uses nomos to describe the 'rule' Antigone followed in honouring her brother over Creon (Ant. 908), and in Electra's desire not to live by nomoi that demand a just action with a harmful consequence (El. 1043). Hence, the ability of people to

\footnotetext{
${ }^{13}$ Ostwald (1969): 23.

${ }^{14}$ Ostwald (1969): 44.

${ }^{15}$ Ostwald (1969): 47.
} 
refuse to accept the force of nomoi is evident, and the unwritten nature of much nomos enables a certain fluidity of understanding and application. ${ }^{16}$

Both nomoi and thesmoi possessed the status of law in ancient Athens during different periods. However, Ostwald claims that they "approach the notion of statute from opposite directions." ${ }^{, 17}$ While thesmoi were imposed from the top down, nomoi achieved validity through their acceptance at grass roots level. Relevant here is Ober's analysis of major approaches to power. The first approach, the 'coercive paradigm', centres power in the state and bases itself on force. ${ }^{18}$ People obey laws or face punishment, and generally have little or no input into the creation of the law. The second approach, the 'discourse paradigm', focuses on the dissemination of social and political knowledge throughout society, and has no centralised locus of power. ${ }^{19}$ Power, therefore, is productive rather than oppressive. Due to the power of rhetoric in classical Athens, Ober suggests that the 'discourse paradigm' offers a more useful tool for understanding the politics of Athens. Where such is the case, the idea of nomoi as the prevailing form of law after the end of the sixth century is unsurprising, and the centrality of discourse is a significant factor in the further development of dikastic power. With the growth of isonomia in Athens, the force of nomos over thesmos through political dialogue became a cornerstone of the growth of demokratia. However, the place of coercion

\footnotetext{
${ }^{16}$ Hart refers to such fluidity as the "open texture" of law, see Hart (1961): 128-36; also Harris (2000): 27-79; Rubenstein (2000): 41-58.

${ }^{17}$ Ostwald (1969): 55.

${ }^{18}$ Ober (1996): 88-9; cites Hobbes, Leviathan [1651], Locke, Two Treatises of Government [1689].

${ }^{19}$ Ober (1996): 89-90; cites Foucault, Discipline and Punish: The Birth of the Prison (1975), The History of Sexuality (1980a), Power-Knowledge: Selected Writings and Other Interviews (1980b).
} 
remained in law, though the community at large took ownership of punishment rather than allowing individuals to pursue private retribution, and it is particularly evident in the use of psêphismata as a form of law.

The common translation of the term psêphisma is "decree". With the emergence of a democratic ekklêsia after the time of Cleisthenes, laws started to become subject to the popular vote. The psêphisma is, in simple terms, the voted decision of the ekklêsia. More specifically, however, psêphismata are decrees of the ekklêsia on a particular issue. ${ }^{20}$ Psêphismata tend to be ephemeral and temporary measures and tend not to set legal precedent, though at times they were relied on in such a way. ${ }^{21}$ However, there are examples of permanent rules enacted by psêphismata. ${ }^{22}$ Certain penalties could only be set by psêphismata after discussion in the ekklêsia, for example the death penalty and declarations of war. ${ }^{23}$ Low claims that all treaties were psêphismata. ${ }^{24}$ Any citizen who wished (ho boulomenos) could propose a psêphisma at an ekklêsia. ${ }^{25}$ Aristotle claimed that an extreme dêmokratia was a system run by psêphismata (Pol. 1292a6). ${ }^{26}$ In the fifth century, a psêphisma was similar in status to a nomos. ${ }^{27}$ However, in the fourth century, Athenians accepted nomos as more authoritative than psêphisma, as nomoi required a more rigorous

\footnotetext{
${ }^{20}$ Tarbell (1889): 79; Sealey (1982); for an early use of psêphismata in such a way, see Aeschylus, Suppliant Women, 601, produced in 463 BC.

${ }^{21}$ Aristotle, EN. 1137a31-1138a2; Ostwald (1986): 407; Ober (1989): 96.

${ }^{22}$ For example, And. 1.93; Dem. 57.31, 34; Lycurg. 1.124-5; Lys. 26.9, 20; Hansen (1989): 188-91 connects most of these psêphismata to the restoration in 403/2 BC.

${ }^{23} I G^{2} 144$, see Hansen (1989): 121.

${ }^{24}$ Low (2007): 86 n.38.

${ }^{25}$ Ober (1989): 109.

${ }^{26}$ Lintott (1992): 127.

${ }^{27}$ Xenophon, Hell. 1.7.20, 23 refers to the law of Cannonus as both a psêphisma (20) and a nomos (23); Ostwald (1986): 96; MacDowell (1978): 45; Hansen (1978): 316; Hansen (1991): 161.
} 
inquiry to become law. Nevertheless, expedience meant that Athens continued to legislate by way of psêphismata. One of the key aspects of psêphismata was the severity of punishment, and the clear intention that the dêmos was its source. Psêphismata were the ultimate positive law of the dêmos, unencumbered by broader principles of justice or law. Hence, psêphismata could pursue the will of the dêmos efficiently. In terms of legal authority, however, democratic nomos in the fourth century remained authoritative.

Prior to $464 / 3 \mathrm{BC}$, four nomos-compound words appear that are important conceptual terms in understanding the Athenian idea of law, being eunomia, dysnomia, paranomia, and isonomia. Eunomia refers to the proper governing of a state, and leads to a healthy social environment of law and order. ${ }^{28}$ For Bacchylides (15.53-6) and Homer (Od. 17.487) eunomia is a force of restraint in opposition to hybris. Dysnomia is its opposite, a point made strongly in Solon (fr. 3.31-2). Tyranny is a consequence of dysnomia, and places people under subjection (doulosunê). ${ }^{29}$ Paranomia is a quality of individuals who explicitly transgress nomoi, and relates to anomia, which is a general state of lawlessness. ${ }^{30}$ The lawlessness of citizens creates a condition void of nomos and dikê under which tyranny develops. ${ }^{31}$

Isonomia is a principle of political equality that emerged most emphatically at the time of Cleisthenes. ${ }^{32}$ Alcmaeon (fr.4) contrasts isonomia

\footnotetext{
${ }^{28}$ Ostwald (1969): 62; Raaflaub (2004): 39 lists eunomia, "good order", as one of three necessary conditions for freedom, along with peace (eirênê) and justice (dikê).

${ }^{29}$ Raaflaub (2004): 55.

${ }^{30}$ Ostwald (1969): 85.

${ }^{31}$ On tyranny, or turannoi, generally, see Anderson (2005).

${ }^{32}$ For a discussion on the more ancient roots of equality, see Morris (1996).
} 
with monarchia in a way that envisages "the preponderance of one member of a pair of opposites over the other., ${ }^{, 33}$ Monarchy is an excess of power in one part of the body, while isonomia is a balance, which in political terms translates to a situation whereby the power of those governed balances the power of those who govern. Aristotle articulates the idea in the Politics where he states that it is the virtue of the citizen to know rule from both sides ("to rule and be ruled" $1277 \mathrm{~b} 15) .{ }^{34}$ Without explicitly using the term demokratia, Alcmaeon defines the basis for the democratic constitution in terms of a body politic under which there is "equality of nomos for ruler as well as ruled."35 According to the Harmodius skolion, when Harmodius and Aristogeiton killed the tyrant, they made Athens isonomos. ${ }^{36}$ Thucydides describes the aristocratically governed state of Thessaly as a dynasteia, contrasting it with isonomia (Thuc. 4.78.3). However, the Thebans use the term isonomos oligarchy (Thuc. 3.62.3), and a Syracusan politician uses isonomia in a way that suggests that it can mean equality among a group, and not necessarily general equality per se (Thuc. 6.38.5). Hence, despite its demand for equality, isonomia could apply to a limited political body such as the Athenian dêmos, which was composed of adult male free citizens. Isonomia at Athens goes hand in hand with the Athenian democratic ideal of political freedom (eleuthêria), which Hansen argues entails freedom to participate in running

\footnotetext{
${ }^{33}$ Ostwald (1969): 100-1.

${ }^{34}$ Ober (1998): 314.

${ }^{35}$ Ostwald (1969): 106

${ }^{36}$ Athenaeus, $15.694 \mathrm{c}-695 \mathrm{f}$
} 
political institutions, and the freedom to do as one pleases. ${ }^{37}$ Isonomia embodied eunomia, and held the prerequisite conditions for Athenian dêmokratia.

Herodotus contrasts isonomia with tyranny and oligarchy in the debate between the three Persian nobles in $522 \mathrm{BC}(3.80-82)$. Otanes states,

Under a government of the people a magistrate is appointed by lot and is held responsible for his conduct in office, and all questions are put up for open debate (Hdt. 3.80).

Maeandrius' motivation for renouncing his inherited tyranny is a desire to live by an equalitarian principle, under which no man should seek "irresponsible power over people as good as himself" (Hdt. 3.142-3). For Thucydides, isonomia is also a political principle that implies both an equality of political rights, and the potential exercise of political power. ${ }^{38}$ In Thucydides (3.82.8), democrats speak of isonomias politikês (political equality) to counter the oligarchic cry of 'rule of the best' and its aristocratic implications. ${ }^{39}$ Of note is the absence of any mention of isonomia by name in Pericles' praise of dêmokratia in his funeral oration (Thuc. 2.35-46). Thucydides associates isonomia with plethos ('common people'). Hence, the democratic war cry is one of 'political equality for the masses'. ${ }^{40}$ For both Herodotus and Thucydides isonomia is not a form of government, but rather a political principle that determines the allocation of power where power is viewed "in

\footnotetext{
${ }^{37}$ Hansen (2004): 17-5; cites Aristotle 1317a40-b17; for uses of eleuthêria see Eur. Supp. 4068; Hdt. 1.83.2-3; Isoc. 20.20; Lys. 26.5; Thuc. 2.37.2; 7.69.2.

${ }^{38}$ Ostwald (1969): 113.

${ }^{39}$ For a discussion of political equality, see Raaflaub (1996).

${ }^{40}$ Ostwald (1969): 115.
} 
the middle" (es meson) and contestable. ${ }^{41}$ While Herodotus' Otanes views isonomia as political equality of citizens generally, Thucydides thinks of it as equality between the power of the upper classes and that of the majority. ${ }^{42}$ Political power is therefore contestable between the Athenian elites and the plêthos. Isonomia required laws that applied to all citizens regardless of wealth or status and with time, the desire for such laws to be written grew.

The fact of writing down laws tends to imply a sense of authority and public record. The essential step in establishing law was the publication of a set, or code, of laws. ${ }^{43}$ The codes of Draco and Solon had support and found general acceptance. ${ }^{44}$ Such publications became a form of legislation by which “the actual rules...governing the operation of a community's judicial system should be made publicly available for all to read and to employ in a legal action...", which meant that the law became a part of the everyday lives of citizens, and therefore were public business. ${ }^{45}$ The earliest explicit reference to written civic nomos is in $425 \mathrm{BC}$ in Aristophanes' Acharnians (532) where Dicaeopolis refers to the Megarian Decree as "nomous hosper skolia gegrammenous". In this example, there is a clear connection between nomos and psêphismata. More relevantly, Euripides refers to "nomôn graphai" in the Hecuba (866) as a barrier to acting in accord with one's own moral judgment, essentially a claim that nomos acts as a restraint on physis. Andocides (1.87) shows that nomos after $403 \mathrm{BC}$ in a political or juridical sense is a reference to

\footnotetext{
${ }^{41}$ Cartledge (2000): 11-12; on power as es meson, see Nightingale (2007): 181-2.

${ }^{42}$ Ostwald (1969): 116.

${ }^{43}$ Gagarin (1986): 132.

${ }^{44}$ Rhodes (1980): 305.

${ }^{45}$ Gagarin (1986): 133.
} 
written law. Democratic Athenian laws ultimately found their authority in the sanctioning of the polis, rather than in divine ordinance, through the decision of the ekklêsia and the judgement of the dikastêria. However, written laws did not play a strong role in litigation. Literacy rates were low, and the thesmothetai in Athens kept a written record of rules purely for their own use (Arist. Ath. Pol. 3.4). Litigants therefore had to argue their position based on Athenian custom, which opened the lives of opponents to investigation in legal cases.

Given the rise in the strength of the idea of the polis, the development of law and legal processes appear to go hand in hand with a tendency toward the polis taking greater control over the lives of its citizens. ${ }^{46}$ As cities grew and became more centralised, order became more important and conflict resolutions needed to be more transparent and accessible. ${ }^{47}$ Where traditionally families maintained self-regulation and sought resolution among themselves, the centralised polis meant that families and individuals began to turn to judicial institutions to settle disputes. ${ }^{48}$ Written codes such as Draco's, which established procedural as well as substantive laws, facilitated the process, often enabling parties to reach extra-judicial settlements on a reasonable basis where appropriate. The dêmos' desire to exercise control over individuals and families ultimately became evident through the vehicle of written law. The clarification achieved led to greater use of dikasteria, which eventually became the legitimate and authoritative body for deciding the appropriate

\footnotetext{
${ }^{46}$ Gagarin (1986): 135-6.

${ }^{47}$ Gagarin (1986): 135.

${ }^{48}$ Gagarin (1986): 139.
} 
application of a particular law. Solon increased the ideal of citizen duty toward the polis, an idea that grew in the dêmokratia to the point that Aristotle claimed that "man is by nature an animal of the polis (zôon politikon)" (Arist. Pol. 1253a2-3). ${ }^{49}$

Gagarin makes an important observation on the question of whom or what written law strengthened. Rather than strengthening the supporters of a particular form of government, written law ultimately supported whichever group happened to be ruling at the time, due to the reduction in intra-familial feuds and the increasing reach of judicial institutions. ${ }^{50}$ The aim, therefore, of Athenian elites was to claim the political high ground through military leadership and ostrakophoriai in the early fifth century, while the democratic institutions such as the ekklêsia or dikastêria became the key arenas towards the end of the fifth century. Political power within the dêmos therefore became necessary to have effect over the laws beyond the minimum level of participation guaranteed under the politeia generally. Although much of the citizen body may have benefited from the existence of written law in that they could at least know what it was, there was still significant trouble in finding the law. While written laws and their related procedures and sanctions helped to protect the democratic elements in Athens, they also enabled non-democrats the ability to create a playing field within which to function. Law could be useful for legal process, but also became a political tool.

\footnotetext{
${ }^{49}$ Gagarin (1986): 140; on citizen rights and duties see Todd (1993): 182-4 and Ostwald (1996).

${ }^{50}$ Gagarin (1986): 141.
} 
Towards the end of the fifth century, a desire for compiling all of the Athenian laws emerged. Written laws were frequently scattered around the city on stones and genuine authority was difficult to establish. In $410 \mathrm{BC}$, following the first oligarchic revolution, the Athenians elected a group of officials as anagrapheis to gather the laws of Solon and Draco and inscribe them into an official set of legitimate laws. ${ }^{51}$ After the end of the Peloponnesian War and the restoration of dêmokratia in $403 \mathrm{BC}$, two boards of nomothetae sat with the boule to scrutinise the laws and post them publicly in stone. ${ }^{52}$ Henceforth, all laws had to pass through the nomothetae, and psêphismata were made subordinate to nomoi. The project of codification finished in $399 \mathrm{BC}$, at which time they were written on papyrus and kept in the Metroon. ${ }^{53}$ Litigants in the dikastêria could then draw on publicly recorded nomoi as a source of authority for legal arguments.

Around the time of the establishment of the nomothetae, a new procedure came into play for creating and amending nomoi. Nomoi had to pass the vote in the ekklêsia, and then face scrutiny by the nomothetae. ${ }^{54}$ Notably, the nomothetae, as with the jury, were accepted representatives of the dêmos as a whole.$^{55}$ However, the nomothetae could not initiate nomoi, the inspection of nomoi occurred only after referral from a citizen at an ekklêsia meeting, and

\footnotetext{
${ }^{51}$ MacDowell (1978): 46.

${ }^{52}$ MacDowell (1978): 47.

${ }_{54}^{53}$ MacDowell (1978): 48.

${ }^{54}$ On the appointment and proceeding of nomothetae, see MacDowell (1975): 73-4; Rhodes (1984).

${ }_{55}$ MacDowell (1978): 48-9; Ober (1989): 147 claims that "the part (dikastêrion) stands for the whole (dêmos)".
} 
they could only inspect nomoi and not psêphismata. ${ }^{56}$ Consequently, the nomothetae acted only as a partial check on the ekklêsia's law-making ability. A further important check was the graphê paranomôn, established sometime after $428 \mathrm{BC}$, which held individual citizens accountable for the nomoi they proposed. $^{57}$ While its companion action, the graphê nomôn mê epitêdeion theinai, is the topic of chapter four it is pertinent to mention that the graphe paranomôn became a strong tool for establishing consistent and reliable nomoi within the demokratia, a position that was enhanced by the codification of Athenian law.

The codification process drew strong support among the oligarchic ranks within Athens. A strong principle that emerged with the first oligarchic revolution in 411/10 $\mathrm{BC}$ was a return to patrioi nomoi, or ancestral laws, and their links with the reforms of Solon (Ath Pol. 29.2-3), which were key to the patrios politeia. ${ }^{58}$ To establish the patrios politeia a group of anagrapheis investigated the patrioi nomoi after the first revolution (Lys. 30.2; Ath. Pol 29.3), and the Thirty received a mandate to draft them in 404/3 BC (Xen. Hell. 2.3.2). ${ }^{59}$ However, there was also a common belief of an intimate connection between the dêmokratia and the patrios politeia. ${ }^{60}$ Consequently, there grew a steady debate as to which version of the patrios politeia would succeed. ${ }^{61}$

\footnotetext{
${ }^{56}$ MacDowell (1978): 49.

${ }^{57}$ MacDowell (1978): 50-2.

${ }^{58}$ Ostwald (1986): 367; 372 .

${ }^{59}$ Ostwald (1986): 416.

${ }^{60}$ For example Andocides (1.95), refers to Demophantus' decree as one of Solon's laws, even though it was passed in 410 BC, see Gagarin \& MacDowell (1998): 127 and note; Thucydides (8.76.6) criticises the oligarchy in 411 for abolishing the patrioi nomoi, whereas the democratic army sought to uphold them; Ostwald (1986): 415.

${ }^{61}$ Strauss (1993): 185.
} 
Patrios politeia, therefore, became a topos to which orators could refer to garner support without alienating large parts of the community. By corollary, in the dikasteria of the fourth century Solon's laws became a reference for legal and political legitimacy. ${ }^{62}$ With tradition established as a factor in law, a common discussion grew around the necessity for citizens to possess a nature that conformed to the purported Athenian character. Hence, the physis of a citizen could come under scrutiny for its conformity with Athenian nomoi.

One of the key debates in Athens was the tension between nomos (law/custom) and physis (nature). Hesiod perceives nomos as god-given practices or norms, but without the implication that such laws are 'natural'. ${ }^{63}$ For Heraclitus, the divine law is itself a law of nature, which conflates the ideas of nomos and physis in favour of a world of unity that law helps to protect and perpetuate. ${ }^{64}$ Thucydides expresses the great law of nature, where the Athenians explain to the Melians,

Of the gods we believe, and of man we know, that by a necessary law of nature they rule wherever they can. And it is not as if we were the first to make this law, or to act upon it when made: we found it existing before us, and shall leave it to exist for ever after us; all we do is to make use of it, knowing that you and everybody else, having the same power we have, would do the same as we do (5.105.2)

The Athenians' position in the dialogue is reflected in the moral paradigm of Plato's Callicles, who claims it as a rule of justice that the strong should by

\footnotetext{
${ }^{62}$ For examples of orator's use of Solon, see Aesch. 1.22-32, 3.2, 38; Dem. 20.90, 93, 22.2532, 24.148, 198, 212; Hyp. 5.22; Isoc. 7.24-5.

${ }^{63}$ Long (2005): 414.

${ }^{64}$ Long (2005) 418.
} 
nature dominate the weak (Gorgias. 583). Athens can dominate Melos by nature, and to an observer it may choose not to. However, the strength of such a nomos means that the possibility of choice no longer exists for the agent of justifiable action. Consequently, it is a natural necessity, reminiscent of a thesmos, which commands Athens to dominate Melos.

The nomos/physis debate found great currency among the sophists in Athens, and their arguments in relation to law appear succinctly in Plato's Gorgias (483c-e). Callicles conceives of "justice according to the law", and "justice according to nature". Justice according to the law is "the purely conventional principle that doing wrong to others is shameful and unjust. As such, it is adopted by the weak to protect them against the strong." 65 Justice according to nature shows that it is just for the superior man to have more than the inferior has, and the more powerful than the less powerful. ${ }^{66}$ For Callicles the principle is moral, and the more powerful will be acting in accordance with justice to dominate the weaker. Such a position consequently justifies aggression and domination, and reflects the coercive paradigm of law above. ${ }^{67}$ For Aristotle, physis is goal-oriented, and ultimately teleological. ${ }^{68}$ In the Rhetoric (1.13), Aristotle distinguishes between 'particular' and 'common law'. ${ }^{69}$ He refers to 'common law' (koinos nomos) as 'natural', as “everyone's virtual intuition that there is a naturally common justice and injustice, which is independent of any mutual association or agreement" and he cites Sophocles'

\footnotetext{
${ }^{65}$ Long (2005): 419-20.

${ }^{66}$ Long (2005): 420.

${ }^{67}$ See above, page 17.

${ }^{68}$ Long (2005): 422.

${ }^{69}$ Long (2005): 423.
} 
Antigone where Antigone declares that it was right for her to bury her brother in defiance of Creon's command. For Aristotle, laws are the "non-natural element to political justice" pertaining only to their particular political context. ${ }^{70}$ Further, the authority of law lies only in the custom of obedience (Pol. 1269a20). Hence, for Plato and Aristotle law is a human institution, which may or may not reflect the natural order, and it is "humanly natural" for citizens to adhere to the rule of law. ${ }^{71}$

The nomos/physis debate is useful in understanding law within the Athenian dêmokratia. The great law of nature (physis) is that the strong rule the weak. ${ }^{72}$ The law (nomos) reverses the natural order by allowing the weak to defend themselves, and even overpower the strong. Under the dêmokratia, the many weak are able to wield the law against the few strong. Individually, oligarchs tended to be more powerful than were the individual members of the dêmos. Hence, in the natural order they would rule. However, once assembled, the collected dêmos held considerable power over the oligarchs. Hence, the democratic law can be considered a reflection of the natural order, which is essentially Socrates' response to Callicles' position (Gorgias, 489b). Consequently, the push for written law and the force of nomoi over psêphismata at the end of the fifth century by the oligarchic faction is an attempt to reverse the natural order. By creating mechanisms to limit the absolute and arbitrary power of the demos, oligarchs sought to reserve for themselves power within the demokratia. The rule of law, in sophistic terms, is

\footnotetext{
${ }^{70}$ Long (2005): 423.

${ }^{71}$ Long (2005): 423.

${ }^{72}$ Thucydides, 5.105.2, above; see also 5.89 .
} 
an unnatural order. However, for elite authors such as Plato and Aristotle, the rule of law provides a natural balance to the order of the polis. The nomos/physis debate remained a constant issue within the Athenian intellectual sphere, and people made arguments about law based on their particular perspective. Consequently, the nomos/physis debate became an underlying topos in law court arguments, particularly when litigants would try to create an image of their opponent as a person whose character conflicted with that of the dêmos, and who was therefore not fit to live within the polis. Dêmokratia required obedience to its law in a legal sense, but the socio-religious sense that had links with ancient thesmoi remained as a force upon Athenian nomos throughout.

While it is difficult to gain a full appreciation of how ancient Athenians understood law, there is sufficient evidence to establish an understanding of what form the idea of law took. In early pre-civilised society, the law was largely the realm of the king. With the increasing communal aspect of the emergent polis society, the desire for knowledge of and accountability to the laws grew. Centralised communities required centralised legal mechanisms and thesmoi, with their strong religious and moral obligations, were the tool for establishing order. Once written, people began to think about law in a different way, and soon the desire for political equality forced a different approach to law making. Whereas previously law was an imposition, under the principle of isonomia the Athenians constructed a law making mechanism that 
ensured all citizens had the opportunity to contribute to the formation of the law. Equality required balance, and law became a balancing mechanism. Nomoi became the new form of law, and psêphismata served a useful functionary role. Obligation to the law then became an issue between the dêmos and its citizens, and a state of eunomia could be achieved through sound legal mechanisms. By the end of the fifth century, the Athenian dêmokratia had formed a strong sense of connection with the early lawmaker Solon and his reforms, which composed the ideal of the patrios politeia. However, oligarchic factions within the dêmokratia saw in the patrios politeia a way to check the dêmos' rampant use of psêphismata by asserting the force of nomos. As a result, the codification of law became a reality in $399 \mathrm{BC}$. Written law, particularly nomos, gained authority in the dêmokratia, and the dikasteria had the ability to interpret and apply the law as it saw fit. Consequently, law became a publicly held institution, the rule of law emerged as a topos, and the dikastêria eventually grew as the body that many powerful citizens turned to for political and social support. The dikastêria also became the arena for disputes of a personal and theoretical nature. 


\section{Chapter 2}

\section{Dêmokratia and the Emergence of the Rule of Law}

The dêmokratia of the fifth century came about after the revolution of 508/7 BC and the resulting reforms of Cleisthenes, followed later by the reforms of Ephialtes. ${ }^{73}$ Based on the principle of isonomia, Cleisthenes issued a program that found its basis in the Solonian constitution, but with a different focus. Solon, building on the principle of eunomia, established a firm basis for citizenship and created the legal principle of ho boulomenos, which offered all citizens the ability to prosecute another for a crime against the polis with the aim of eliminating the need for self-help in the Athenian legal system. Cleisthenes, however, established isonomia as the basis for his reforms in the late sixth century. The subsequent growth of the dêmos as the source of law in the fifth century became the basis for demokratia, as it provided the polis with the ability to achieve the necessary standard of accountability to the dêmos. Accountability to the dêmos gave the dêmos ultimate control over its affairs through the power to punish citizens and officials who transgressed its laws. However, the dêmos too eventually became accountable as to how it behaved, particularly toward elite minorities within the demos. Legal actions such as the graphê paranomôn established checks on the dêmos, and the dikastêria became an arena for challenging legal and political propriety. Hence, the rule of law provided the dêmos with the ability to hold the key power over the Athenian polis, but also made the dêmos generally accountable to its own

\footnotetext{
${ }^{73}$ Ober (1989): 34-5; Rihil (1995): 87.
} 
standards. Written laws of the fourth century ostensibly found their basis in long held customary practice and the patrios politeia, leaving the rule of law in the Athenian dêmokratia as a tool for orators to manipulate toward their own ends.

The three core institutions of the Athenian dêmokratia were the ekklêsia, the boulê, and the dikasteria. The ekklêsia consisted of the body of male citizens over eighteen who gathered to discuss and vote on laws and the government of the polis. ${ }^{74}$ Official acts of the polis as a whole proceeded according to nomoi or psêphismata, or at least found legitimisation in retrospective nomoi or psêphismata, which allows Ober to promote the idea of nomoi as "speech-acts". ${ }^{75}$ Meetings of the ekklêsia began with a Herald asking, "Who wishes to speak?",76 Votes were generally taken by a show of hands (Xen. Hell. 1.7.7), but voters also at times used pebbles as ballots (Xen. Hell. 1.7.9). Assemblies appear in the earliest sources, such as the one Achilles calls at the beginning of the Iliad (1.58). Such assemblies tended to be led by aristocratic heroes, and the plêthos supported the hero's leadership. Solon gave thêtes, the poorest class of Athenians, the right to sit in the Archaic Athenian ekklêsia (Ath. Pol. 7.3). The democratic Athenian ekklêsia later emerged when the reforms of Cleisthenes supported the political force of the united Athenian dêmos against the standing eponymous archon. After the reforms of Ephialtes,

\footnotetext{
${ }^{74}$ Hansen (1991): 129.

${ }^{75}$ Ober (1996): 8; on "speech-act theory", see J.L. Austin (1975).

76 “ti\&j a)goreu\&ein bou\&letai” Dem. 18.191; see also Aesch. 1.26; Aristoph. Ach. 46-7, Ekkl. 130.
} 
the ekklêsia became synonymous with the dêmos. ${ }^{77}$ Under these reforms, the ekklêsia gained the power to discuss and vote on laws, and maintained some judicial functions. Most importantly, the dêmos gained control of the processes of dokimasia and euthyna, which allowed it to be the ultimate arbiter of official suitability and accountability.

Of vital importance to the ekklêsia was isêgoria, which included the right of every citizen to speak freely. ${ }^{78}$ Isêgoria was, in fact, a prerequisite for proper public debate (Plato, Rep. $8.562 \mathrm{a}-64 \mathrm{a}) .{ }^{79}$ For Plato, isêgoria makes the rule of law possible (Rep. 563d7-e1). Demosthenes mentions isêgoria as a particularly important feature of dêmokratia (60.26), and claims that Theseus established it in the Athenian dêmokratia (60.28). Nevertheless, while the dêmokratia allowed all citizens the right of isêgoria, it did not require everyone to speak publicly (Dem. 18.308; 22.30). Isêgoria also had a social aspect that ensured people of all status or position could present themselves freely to others. The young Cyrus describes the ability of a king and his subjects to sing and socialise together as a condition of isêgoria (Xen. Cyr. 1.3.10). Isêgoria includes equality between slave and free, and alien and citizen, as the polis relies on the slave and the alien for its economic and social survival (Xen. Ath. Pol. 1.12). Herodotus observes that Athenians under isêgoria fight better than when they are "held down by authority", which suggests that the very security of the state is secured by isêgoria (Hdt. 5.78).

\footnotetext{
${ }^{77}$ Note that dêmokratia had already begun to be used as the term for the politeia, see Aeschylus, Supp. 604. After the reforms of 462/1, dêmokratia became the formal designation. ${ }^{78}$ Dem. 15.18; Hansen (1991): 81; Ober (1989): 296.

${ }^{79}$ Galpin (1984): 101.
} 
The boulê was a Council of citizens over 30 years old, selected by lot to sit for a full term of a year, which dealt with the government of the polis. ${ }^{80}$ Under Draco, the boule consisted of 401 members selected by lot (Ath. Pol. 4.3). Solon's boulê consisted of 400 members, being 100 from each of the four tribes (Ath. Pol. 8.4). It was after Cleomenes' attempt to abolish the boule that the dêmos rose up and asserted itself as a self-defined political unit (Ath. Pol. 20.3). ${ }^{81}$ Cleisthenes then set up his boulê as a representative of the dêmos on which 50 citizens from each of the ten tribes sat (Ath. Pol. 21.3) ${ }^{82}$ Boulê representation gave individual demes, and therefore their citizen members, access to political power in Athens. Aristotle lists the boule in a dêmokratia as the most important board of magistrates (Arist. Pol. 1322b). Key to the function of the boulê was that it prepared business for the ekklêsia, including deciding what proposed laws the ekklêsia would discuss. ${ }^{83}$ Demosthenes refers to an instance when the ekklêsia gathered to discuss an issue before the boulê could produce a proposal, and claims that the ekklêsia passed his decree (Dem. 18.169-79) ${ }^{84}$ Such instances, however, were uncommon. Together, the ekklêsia (legislative) and boulê (executive) represent the essential bodies of democratic Athenian lawmaking. ${ }^{85}$ While the ekklessia debates and votes on laws, the boule controls which laws it receives, acting as a vetting process.

\footnotetext{
${ }^{80}$ Rhodes (1972): 6-7.

${ }^{81}$ Ober (1989): 68-9.

${ }^{82}$ Rhodes (1972): 1.

${ }^{83}$ Blackwell (2003): 24.

${ }^{84}$ Moore (1986): 282.

${ }^{85} \mathrm{Nb}$ : The ekklêsia maintained certain executive and judicial powers. The separation of powers here is somewhat artificial, though has some merit.
} 
The dikastêria consisted of 6,000 ordinary Athenian citizens chosen by lot. ${ }^{86}$ Juries generally consisted of 501 members, but could be larger or smaller depending on the type and importance of the case (Ath. Pol. 68.1) ${ }^{87}$ Athenians perceived large, randomly selected juries as un-bribable. Jurors decided their verdict based on the speeches of prosecutor and defendant, and voted by way of casting a ballot. ${ }^{88}$ The litigant with the most votes won, and in the event of a tied vote, the case went to the defendant. ${ }^{89}$ Of note is the absence of a judge with expert legal knowledge. Athenian jurors acted as judge and jury, and orators consequently had to rely on their powers of persuasion in attempting to affect their perspective of justice, particularly on issues for which there was little in the way of law to guide decisions. It was up to the dikastêria to determine what the law was, to make judgements on it, and to enforce it. The clarification of the Athenian constitutional make up and the codification of the laws at the end of the fifth century established a platform for the ideal of the rule of law as a topos in constitutional terms. By establishing clearly defined laws and legal procedures, the Athenian constitution strengthened the jurisdiction of the dikasteria, specifying areas of law to investigate and therefore giving it greater power over those areas. Although discretionary powers were ostensibly reduced, formal legal powers were enhanced.

Part of Solon's package of reforms was the implementation of the graphê. The graphê enabled any citizen who wished (ho boulomenos) to bring

\footnotetext{
${ }^{86}$ On the social make-up of juries, see Todd (1990).

${ }^{87}$ Ostwald (1986): 68-9.

${ }^{88}$ Boegehold (1963): 366-67.

${ }^{89}$ Ath. Pol. 69.1; Boegehold (1963): 367; see the Eumenides (734-43), where Aeschylus has Athene cast the tie vote, which favours Orestes.
} 
a case against any other citizen for certain public crimes against the entire community. An action of graphê required the existence of courts of some kind, without which legal rights and obligations would otherwise remain inchoate. The concept of graphe carries the intent of isonomia, in that all citizens theoretically have access to legal process irrespective of social position. In taking a graphê, a citizen was giving life to the laws, which remained a fiction without such action. ${ }^{90}$ So too the procedure of ephesis, by which magistrates' decisions could be appealed, asserted legal equality and popular power. ${ }^{91}$ Hence, with the adoption of isonomia as a guiding principle under Cleisthenes, there is an expectation that the law court would become more significant. However, the Areopagus remained the moral guardian of the laws according to Solon's laws (Ath. Pol. 8.4), and there is little evidence to suggest that Cleisthenes altered judicial arrangements. ${ }^{92}$ The dikasteria emerged as a fully formed judicial body only after the reforms of Ephialtes.

Isonomia, Cleisthenes' guiding principle, became the organising political principle of the Athenian polis. Ober lends weight to Herodotus' claim (6.131.1) that Cleisthenes brought about dêmokratia at this time. ${ }^{93}$ Cleisthenes was not a lawgiver in the same way as Solon. His leadership had no constitutional basis but was based on his ability to garner support from the dêmos, which suggests that dêmokratia was "the product of collective

\footnotetext{
${ }^{90}$ See Dem. 21.224.

${ }^{91}$ Ostwald (1986): 48.

${ }^{92}$ Smith (1925): 111.

${ }^{93}$ Ober (1989): 34-5; Herodotus is supported in the primary sources by Isocrates (15.232). Aristotle claims that Cleisthenes simply made the constitution more democratic (Ath. Pol. 22.1); the oligarchs involved in the revolution of $411 \mathrm{BC}$, however, did not consider Cleisthenes' constitution to be democratic, but rather Solonic (Ath. Pol. 29.3).
} 
decision, actions, and self-definitions on the part of the dêmos". ${ }^{94}$ Ostwald, following the orthodox position, claims that the reforms did not introduce dêmokratia, as the Areopagus controlled the processes of euthyna and eisangelia. ${ }^{95}$ Rather, Ostwald considers Athens after Cleisthenes to be

a government in which a large representative Council and an Assembly of all citizens serve as counterweight and check to the power of an aristocratic and wealthy ruling class. ${ }^{96}$

Consequently, for Ostwald, the reforms of Ephialtes and the containment of the Areopagus to murder trials was the final step to establishing dêmokratia. In general terms, the key democratic feature of Cleisthenes is the effect of isonomia, which offered all Athenian citizens access to power irrespective of class or wealth. ${ }^{97}$ Only with political equality firmly established as a political goal could Athenian citizens gain and exercise their political rights and obligations.

In 487-6 BC, a change meant that the position of archon came about by lot (Ath. Pol. 22.5) that had a degenerative effect on the prestige of the Areopagus. ${ }^{98}$ In $462-1$ BC, Ephialtes secured the place of dêmokratia by removing most of the Areopagus' powers (Ath. Pol. 23). ${ }^{99}$ Equality then became fully established as a fundamental democratic value. ${ }^{100}$ Most of the

\footnotetext{
${ }^{94}$ Ober (1996): 35.

${ }^{95}$ Ostwald (1986): 27-8; on eisangelia generally, see Hansen (1975).

${ }^{96}$ Ostwald (1986): 26-7.

${ }^{97}$ Raaflaub (1996): 146-8, 153 argues that it was only from the time of the Persian War that the thetes achieved a more permanent political stake due to the need for cheap rowers onboard war ships, giving weight to Oswald's position.

${ }^{98}$ Badian (1971); Rihil (1997): 90-1; Smith (1925): 114.

${ }^{99}$ Ostwald (1986): 49.

${ }^{100}$ Raaflaub (1996): 148.
} 
judicial functions of the Areopagus became the realm of the dikastêria. ${ }^{101}$ Most importantly, the dikastêria had authority over questions both of law and of fact, and gained control of the procedures of dokimasia and euthyna. ${ }^{102}$ By giving such power to a body open to any Athenian citizen, Ephialtes was extending to judicial proceedings the isonomia that Cleisthenes had given the people in legislative measures, he created popular sovereignty, which was justly called dêmokratia. ${ }^{103}$

These courts came about through the act of dividing the heliaia, which was the ekklêsia sitting as a court, into a number of dikastêria, each of which acted as an authoritative representation of the dêmos as a whole. ${ }^{104}$ Only then did the dêmos possess the necessary and sufficient power to maintain control of legal and political affairs within the polis. From such a perspective, Ostwald shows that dêmokratia was secured only with the passing of power from the Areopagus to the dikasteria. ${ }^{105}$ Consequently, the strength of the dikasteria became essential to the power of the dêmokratia, and to the emergence of the rule of law.

Despite the desire for isonomia, a citizen with political ambition needed to build prestige and influence. ${ }^{106}$ Prior to the death of Pericles, leaders came from political families such as Cimon's, which held power over four generations. ${ }^{107}$ Trusted due to their familial prestige, they also behaved generously toward the city in the expectation of gaining political support

\footnotetext{
${ }^{101}$ Smith (1925): 117; Ostwald (1986): 67.

${ }^{102}$ Ostwald (1986): 68, 79.

${ }^{103}$ Ostwald (1986): 49-50.

${ }^{104}$ Ostwald (1986): 68; Ober (1989): 146.

${ }^{105}$ Ostwald (1986): 70 cites Aristotle, Ath. Pol. 9.1, 41.2; Pol. 2.12, 1273b41-1274a7.

${ }^{106}$ Connor (1971): 29.

${ }^{107}$ Connor (1971): 10.
} 
through charis, though this remained an unreliable source of support. ${ }^{108}$ Political support also required involvement in a hetaireia, through which political ideas could be argued out and aristocratic support secured. ${ }^{109}$ In addition, a politically ambitious citizen would aim for military leadership through the position of stratêgos as a lever into political power. ${ }^{110}$ Hence, while all citizens were able to involve themselves in speaking and voting at the ekklêsia, personal power still required wealth, coalitions, and family ties. ${ }^{111}$

With the dêmos becoming increasingly united since Cleisthenes' reforms, the dêmos looked increasingly toward its own interests, and expected politicians to follow suit. Irrespective of a politician's true motive, political success meant keeping up the pretence. The Imperial policies prior to Pericles' death served such interests, but internal politics still had an elite bias. Under the demagogues, the self-interest of the dêmos became rampant. Psêphismata had become the standard form of law, unchecked other than by the ability of the boulê to choose what to bring forward for discussion at the ekklêsia. Ostracism, implemented after Cleisthenes and used to ensure no individual citizen became too powerful, had begun to fall into disuse and eventually ceased. The Peloponnesian War led to opportunities for demotic self-interest to express itself clearly, and it did so most brutally at places such as Scione, Torone, and Melos. ${ }^{112}$

\footnotetext{
${ }^{108}$ Connor (1971): 20-2.

${ }^{109}$ Connor (1971): 26-9.

${ }^{110}$ Ober (1989): $91-3$.

${ }^{111}$ Connor (1971): 67-78.

${ }^{112}$ See Thucydides 5.32.1, 5.34, and 5.116; Xen. Hell. 2.2.3.
} 
The post-Periclean era brought about a change that led to the emergence of the rule of law. The dêmos generally lacked the necessary political organisation that would allow it to overcome the influence of traditional elites, and where such leadership was wielded with the dêmos' interests in mind, the dêmos accepted strong leadership. ${ }^{113}$ Strong leaders could dominate because they pursued strong policies of Athenian interest, particularly concerning the empire. However, lack of organisation left the dêmos unable to exercise its full force in tending to its own interests. ${ }^{114}$ Hence, the opening emerged for the introduction to Athenian politics of the ostensibly democratic figure of the demagogue. $^{115}$

The image of the demagogue is best personified in the figure of Cleon. ${ }^{116}$ Previously, leaders established powerful groups of friends who offered blocks of support in the ekklêsia. However, Cleon, in a similar fashion to Cleisthenes, shunned powerful and influential friends in an effort to show himself as a 'man of the people' and thereby gain mass support for his policies. ${ }^{117}$ Crucial to such a policy was the fact that Athenian demokratia relied most on those who traditionally had the least influence, such as the rowers in the navy. ${ }^{118}$ The dêmos came under the influence of the politician who promised it the most,

\footnotetext{
${ }^{113}$ Connor (1971): 89.

${ }^{114}$ Connor (1971): 89 .

${ }^{115}$ Connor (1971): 90.

116 The term used for leaders of the late fifth century was prostatai tou dêmou, "those who stand before the dêmos", Connor (1971): 110-1; Rosenbloom (2004a): 90-93 argues that the power of the prostatai tou dêmou lies in the fact of their representation, and that they personify the "imagined community" by mirroring the character of the polis; the prostatês upholds demotic power as supreme and depicts himself as its protector.

${ }^{117}$ Connor (1971): 92-3.

${ }^{118}$ Connor (1971): 87.
} 
leaving it open to the accusation of being like a prostitute. ${ }^{119}$ Aristophanes makes a notable observation of this process where he has Paphlagon saying, "I love you Dêmos, and I am your erastês" (Knights, 732). The language of "dêmos-lover" and "dêmos-hater" became political topoi in a similar vein. ${ }^{120}$ The message in such language was that the speaker had the interests of the dêmos in mind, while opponents did not. ${ }^{121}$ Political loyalty was henceforward ostensibly to the dêmos rather than to small groups that remained in the background. ${ }^{122}$ The dêmos' interests therefore became even more entrenched as the justification for political action.

The direct contact with the dêmos led to a reversal of traditional political ascent. Previously the usual path for leaders was to lead as a stratêgos before taking a leadership role in politics. However, when Cleon took leadership of the attack on Sphacteria in $425 \mathrm{BC}$ as stratêgos, he was already well established as a political leader (Thuc. 4.27.5-28.3). To achieve success, the demagogues relied on their oratorical ability, making use of it in the ekklêsia, boule, and dikasteria. With the removal of power from the Areopagus, the dikastêria had become more important to the dêmokratia, as citizens were now making more legal decisions, and had taken control of dokimasia and euthyna. Leaders could then lead without the scrutiny applicable to formal leadership. Oratorical skills also offered protection in the self-help legal system of Athenian dikastêria, which encouraged self-reliance, and became a marketable

\footnotetext{
${ }^{119}$ Wohl (2002): 75.

${ }^{120}$ Connor (1971): 100.

${ }^{121}$ Connor (1971): 106-7.

${ }^{122}$ Connor (1971): 105; 118.
} 
skill. Due to the persuasive nature of oratorical skills and the lack of procedures for accountability, politicians could become self-serving to a greater degree than previous politicians could. For example, Aristophanes has the Sausage Seller open his bag to show Dêmos he has given his all for them. However, Paphlagon's bag shows larger portions of cheesecake kept for himself in a fashion that shows he looks toward his own interests while pretending to look after Dêmos' (Knights, 1215-1223). The ability to deceive became a feature, or at least a suspicion (Thuc. 3.43), of late fifth-century politicians. Self-interest became a strong feature of demagogues, who ostensibly asserted the interests of the dêmos while working toward their own advantage. After the battle of Arginusae, the dêmos showed its ability to overrun even its own internal laws when pursuing self-interest.

The naval battle at Arginusae in $406 \mathrm{BC}$ was successful for the Athenians, although they lost 25 ships (Xen. Hell. 1.6.34). ${ }^{123}$ Due to a quickly rising storm, the generals decided they could not afford to recover the bodies of the dead sailors and chose instead to leave them in the water (Xen. Hell. 1.6.35). Athenians were outraged and tried the generals in a single trial, which was illegal under established law. Callixenus' proposal to execute the generals (Xen. Hell. 1.7.9) faced opposition from Euryptolemus by way of a graphê paranomôn that demanded due process (Xen. Hell. 1.7.12-26). However, Euryptolemus faced violence in the ekklêsia at which the crowd cried that "it is shocking not to let the people do whatever they wish" and he withdrew his proposal (Xen. Hell. 1.7.12). As Ostwald put it "for the first time in Athenian

\footnotetext{
${ }^{123}$ Ostwald (1986): 433-43.
} 
history the principle of popular sovereignty was asserted to its logical conclusion." 124 The dêmos behaved "tyrannically" in acting and enacting according to its whim even where such action was contrary to existing law, living up to the potential that earlier critics had foreseen. ${ }^{125}$ Dêmokratia had manifestly become tyranny at the expense of Athenian elites. To gain protection from the plethos, elites had begun to establish a desire for recourse to written and presumably prescriptive laws, which they hoped would limit the power of the dêmos and its leaders, most notably in the commencement of codification in $411 \mathrm{BC}$. Arginusae gave them a clear example of the need to establish a check on the whim of the dêmos. In emphasising recourse to the law, the ideal of the rule of law emerges in a mature form.

Toward the end of the fifth century, disorder in Athens grew. The common reasons given for such disorder are the military losses of the time, and the decline of the Athenian Empire. Thucydides suggests the plague in Athens as the cause of general lawlessness (anomia) (2.53-4). Connor adds a further plausible reason, being the withdrawal of traditional elites from democratic leadership roles. ${ }^{126}$ To use Aristophanes' analogy, Athens possessed good gold coin, but chose instead to use the cheap bronze ones (Frogs, 718-737). ${ }^{127}$ The lack of quality leaders may in fact be the reason for the defeats that led to Spartan victory in the Peloponnesian War. ${ }^{128}$ After

\footnotetext{
124 Ostwald (1986): 444.

${ }^{125}$ For example, Pericles claims that the Athenian empire, internally a democracy, is a tyrant over its allied states (Thuc. 2.63.2); the chorus in Aristophanes Knights states that people fear Dêmos "like a man with tyrannical power" (1113-4).

${ }^{126}$ Connor (1971): 176.

${ }^{127}$ Rosenbloom (2004a): 65.

${ }^{128}$ Stockton (1990): 158 .
} 
securing military victory, Sparta helped abolish the Athenian democratic institutions in $404 \mathrm{BC}$, and assisted the emergence of a new oligarchy. The Thirty, under the leadership of Critias, soon began to act as a tyranny (see Xen. Hell. 2.3.1-56). After much violence and confiscation, Thrasybulus led a counter-revolution that eventually defeated the oligarchy and, after the intervention of the Spartan king Pausanias, established an amnesty for offences during the reign of the Thirty, subject to their passing of euthynai. ${ }^{129}$ The Athenian dêmokratia, for the second time, had been overthrown and survived. The emphasis was then on creating stability.

The restoration of dêmokratia in $403 \mathrm{BC}$ occurred with a desire to move forward. Amnesty helped with this process but was, in itself, insufficient. The outcome of the Sicilian expedition in 415-413 BC finally opened the Athenians' minds to the fallibility of democratic decision-making. ${ }^{130}$ The experiences of the two revolutions left Athenians with a general feeling that dêmokratia was necessary to avoid stasis. ${ }^{131}$ However, the experiences of elite minorities under dêmokratia left them pushing for some form of protection from democratic tyranny. ${ }^{132}$ Under the oligarchy in $411 \mathrm{BC}$ the Athenian law code came under review, the oligarchs of 404/3 BC continued the process, and the Athenian dêmokratia chose to continue the process after the restoration in

\footnotetext{
${ }^{129}$ Ostwald (1986): 499; Stockton (1990): 161-3; on the amnesty, see And. 1.81-5; Arist. Ath. Pol. 39.6; Carawan (2002).

${ }^{130}$ Ostwald (1986): 337; Ober (1998): 69, 98 identifies issues that could have a negative impact on proper decision making such as illegitimate private interests.

${ }^{131}$ Stockton (1990): 163.

${ }^{132}$ Ostwald (1986): 372.
} 
403 BC. ${ }^{133}$ The codification was to be based on the laws of Draco and Solon, according to tradition (And. 1.81-5). ${ }^{134}$ A new process of passing laws emerged that gave the constitution some security, and acted as checks on the rule of the dêmos. After 403/2 BC, laws had to pass through the nomothetae, boule, and ekklêsia. ${ }^{135}$ The process of codification took until $399 \mathrm{BC}$ to complete. These measures, accepted by both democratic and oligarchic factions, effectively established the formal rule of law in the Athenian dêmokratia.

After Cleisthenes' reforms, the main emphasis lay on augmenting the dêmos as a legal and political force. Isonomia entailed political equality, but the constitution had failed to introduce and enforce measures to ensure such application occurred. Part of the problem for Athens was a lack of articulated democratic theory. ${ }^{136}$ Hence, Athenian dêmokratia had no well-argued body of ideals to draw it together. Democratic ideology remained vague and lacked cohesion. Athenian democrats therefore looked to the past, and drew on the patrioi nomoi for their direction in re-establishing dêmokratia (Thuc. 8.76.6). ${ }^{137}$ What constituted patrios, however, was contestable. Democrats took it to mean the demokratia, which the oligarchs rejected; oligarchs connected to hetaireiai took it as confirming an oligarchy; oligarchs without such connections sought to promote the patrios politeia (Ath. Pol. 34.3).

\footnotetext{
${ }^{133}$ See Rhodes (1991); Lys.30; And. 1.81-5 cites the decree of Tisamenus; on the use of terms such as "revision" and "law-code" see Robertson (1990).

${ }^{134}$ Rhodes (1991): 97.

${ }^{135}$ Rhodes (1991): 91.

${ }^{136}$ Raaflaub (1996): 142 cites Kerferd, Sophistic Movement in arguing that Plato's Protagoras $320 \mathrm{c}-323 \mathrm{a}$ is the first and probably only example of a theoretical basis for participatory democracy.

${ }^{137}$ Ostwald (1986): 343.
} 
Disagreement left room for the second oligarchic revolution and the rise of The Thirty, which initially acted with good will aiming at the patrios politeia only to behave viciously toward the citizens of Athens (Ath. Pol. 35.2-4). Following the demise of The Thirty, the project under the restoration generally was not so much a move to strengthen dêmokratia explicitly, but one to establish eunomia under the patrios politeia. ${ }^{138}$ Dêmokratia was the form that eunomia was to take. The ability for written laws to take precedence over the unfettered interests of the dêmos however came only after constitutional rearrangements.

The establishment of the nomothetae began the process of constitutional transformation under an oligarchy of 5,000 hoplites and hippeis, which Thucydides describes as the best form of Athenian government in his lifetime (Thuc. 8.97.2). One of the first measures after the revolution of $411 \mathrm{BC}$ was the introduction of Demophantus' law against overthrowing the dêmokratia (And. 1.96-9; Dem 20.159). Seating in the boule was by lot from 410/09 BC, which helped to prevent interest groups from unduly influencing the passage of laws. ${ }^{139}$ The adoption of the amnesty showed that the dêmos was prepared to subordinate its whim to nomos. ${ }^{140}$ The dêmos pushed for the new constitutional order to be based on the written law code, which itself was ostensibly based on the patrios politeia. Notably, the new laws were not made in the ekklêsia and agreed to by vote, but citizens did have the opportunity to

\footnotetext{
${ }^{138}$ Ostwald (1986): 411.

${ }^{139}$ Ostwald (1986): 418; Philochorus, fr. 140.

${ }^{140}$ Ostwald (1986): 509.
} 
present their views to the boule. ${ }^{141}$ Alterations to the law would then occur by debate at an ekklêsia, but receive their validation from the nomothetae. Ultimately, as Ostwald states,
A new social and political order was created that retained the characteristics of the Athenian democracy while subordinating the principle of popular sovereignty to the principle of the sovereignty of the law. ${ }^{142}$

The emphasis on the place of law is validated by the nomos that stated
A law which has not been inscribed shall not be employed by officials on any matter whatever. No decree (psêphisma) of the Council (boulê) or Assembly (ekklêsia) shall prevail over a law (nomos) (Andoc. 1.87).

While the subject of sovereignty is contestable, the point is that the constitution was finally mixed to what was perceived generally as a fair balance, under which the ekklêsia relinquished the final legislative say to the nomothetae. ${ }^{143}$ The nomos that Andocides refers to shows the emergence of what H. L. A. Hart calls a "rule of recognition", which acts as a remedy for uncertainty over primary rules, and signals the full maturation of the Athenian democratic constitution under the law. ${ }^{144}$ Such constitutional and legal clarity could then be administered through the dikasterria in conjunction with the other mainstays of Athenian dêmokratia, the boulê and ekklêsia. Consequently, the ideal of the rule of law that had begun in the fifth century crystallised into a set of laws and procedures that established the constitutional rule of law, and assured that the dêmos held the kyrios power over the polis.

\footnotetext{
${ }^{141}$ Ostwald (1986): 517.

142 Ostwald (1986): 497.

${ }^{143}$ Lysias refers to the jury's verdict as the "sovereign authority (têi polei kuriotate) over all the city's affairs" (1.36).

144 See Hart (1961): 94-6; Hansen (1991): 170 refers to the law as the "law of definition".
} 
One of the key democratic factors of the dikastêria was the voluntary nature of the system. A public action in court allowed a citizen to take a case and prosecute it himself. This right of ho boulomenos gave citizens the power of initiation of legal proceedings. The right of ho boulomenos was in fact more of a duty to prosecute, and Demosthenes highlights an important feature in this regard, showing that the laws exist only through the citizens of the dêmos (Dem. 21.223-25). The power of the dikasterria comes from the laws, and the power of the laws comes from the ability of the dikasteria to enforce them. Law is a fiction that derives its existence from the dêmos, and is therefore a publicly held force. Citizens were therefore expected actively to defend the city and its laws (Dem. 24.156; 25.21-22; Aesch. 1.2, 4-5; 3.6, 169, 196). As a result, the polis had a shield against abusive or corrupt use of power by officials and wealthy individuals, as well as common criminals. However, such open access also led to the danger of malicious prosecution, and Athenians became highly sensitive to such practice. ${ }^{145}$

Sykophants could use the threat of court action to intimidate citizens, in particular wealthy or powerful individuals. The more experienced a citizen was in dealing with the courts, the more likely he was to be able to exert such pressure. Alternatively, a litigant could attempt to show an opponent as a sykophant in order to gain support. Osborne argues that there is little evidence to prove sykophants prosecuted for self-enrichment. ${ }^{146} \mathrm{He}$ argues that the sykophant helps to protect the dêmos from wealthy and powerful

\footnotetext{
${ }^{145}$ Ostwald (1986): 81.

${ }^{146}$ Osborne (1990): 90.
} 
individuals. ${ }^{147}$ Dêmokratia requires both conflict and consent, and sykophants provide a necessary volume of conflict. ${ }^{148}$ However, according to Harvey, the sykophant threatens the rule of law as he places money before justice, and he cites a list of examples of such use. ${ }^{149}$ In placing money before justice, the sykophant uses the shield of the law as a sword, attacking undeserving citizens, and undermining the intent of law. Sykophants often laid false charges. ${ }^{150}$ Sanctions existed to deter sycophancy, such as the fine for those who dropped a suit before it came to court, and a prosecutor in certain actions who failed to win one fifth of the jury's votes faced paying a penalty to the defendant. ${ }^{151}$ Further, there was a legal action to prevent sycophancy directly (see Ath. Pol. 43.5, 59.3), but a limitation on the number of such cases prevented a self-perpetuating cycle of sycophancy trials.

In Aristophanic comedy, the sykophant is consistently an object of scorn and derision. ${ }^{152}$ Among orators in the dikastêria, the sykophant became the paradigm of an anti-Athenian, and thus an outsider. ${ }^{153}$ The sykophant in Aristophanes' Wealth (929) claims to be a legitimate voluntary prosecutor and therefore protecting the dêmos from criminals by upholding the law. He identifies himself as ho boulomenos rather than sykophantês, suggesting a difference in connotation. The Just Man views the jury as the vehicle of legal

\footnotetext{
${ }^{147}$ Osborne (1990): 96.

${ }^{148}$ Osborne (1990): 99.

${ }^{149}$ Harvey (1990): 110-1 draws support from Isoc. 21.5, 21.8; Dem. 24.41, 25.52, 59.43; Lys. 25.3.

${ }^{150}$ Harvey (1990): 112.

${ }^{151}$ Christ (1998): 29.

${ }^{152}$ See, for example, Acharnians, 719-28, 818-47, 898-958; Birds, 1410-66; Knights, 13971401; Wealth, 30-31, 850-950. In The Assemblywomen, the entire demos is referred to as sykophants (434-54, 554-63).

${ }^{153}$ Christ (1998): 48-50.
} 
justice, ignoring the role of the volunteer prosecutor altogether, and thereby disregarding the sykophant's potential as an agent of justice. Sykophant was, as Harvey shows, a negative term. However, it was used in an ad hoc way, as Osborne claims. ${ }^{154}$ The term sykophant was a freely used term of political abuse according to an archetype. For example, sykophants were blamed for the oligarchic revolution (see Lys. 25.19-30). Consequently, the sykophant is clearly distinguished from the legitimate ho boulomenos prosecutor by the connotations accorded to each role. The free access to justice through the courts that gave the dêmos its most crucial legal power also exposed it to its worst threat, the use of law to bring about injustice for self-enrichment. It was up to the jury to guard the law by upholding it (Lys. 25.3), thereby asserting the rule of law against improper and unjust use.

The way orators used the courts is the subject of the next chapter. However, there are conceptual issues important at this stage. One of the conflicts within the dêmokratia, especially with strong dikastêria, was between popular sovereignty and the sovereignty of the law. ${ }^{155}$ While sovereignty was not a term that appears in the ancient record, it is a concept that was evident. Aristotle (Pol. 1278b9-14) refers to the 'kyrios dêmos' in a way that expresses the concept explicitly, as does Demosthenes (20.107). The kyrios in ancient Greece was the master of the household (oikos). ${ }^{156}$ Aristotle bases his philosophies of economics and politics around the oikos, hence his use of the term kyrios is consistent. Aristophanes, in Knights, refers to Dêmos as

\footnotetext{
${ }^{154}$ Osborne (1990): 93.

${ }_{155}$ Ober (1989): 299-305.

${ }^{156}$ Todd (1993): 383.
} 
tyrannos (1114), monarchos (1330), and basileus (1333). However, the strict demarcation of sovereignty of one body over the other becomes redundant due to the lack of separation of powers within the democratic constitution. ${ }^{157}$ For Athenians, the ekklêsia, boulê, and dikastêria, were all authoritative representatives of the dêmos as a whole. Consequently, whichever institution had ultimate authority over any particular application, the dêmos ostensibly remained kyrios.

Nevertheless, the place of the laws is evident in such strong phraseology as when politicians and orators refer to acting "against the city and its laws" (Dem. 24.156; 25.21-22; Aesch. 1.2, 4-5; 3.6, 169, 196). Such references place the dêmos on a level with the laws, which shows the important place law held for Athenians in the dêmokratia. Hence, Ober's observation that modern tendencies to attempt a reconciliation of the apparent contradiction "misrepresent the Athenian reality" becomes pertinent. ${ }^{158}$ Taking into consideration the ability of orators to manipulate legal process because of the inherent freedom for citizens to do so, the presence of such contradictions as the question of kyrios or sovereignty help create the conceptual fuzz within which the fourth-century orators plied their trade. A gap remained between law as a concept and the law as posited, nomos, psêphisma, and even thesmos. If law must apply to all, it must also be in the interests of all. ${ }^{159}$ Concepts can be used broadly, and broad interpretations of the law based on such concepts can be viewed favourably, or not, by the jury. The justice of the dikastêria

\footnotetext{
${ }^{157}$ Ober (1989): 299; Rhodes (1972): 147.

${ }^{158}$ Ober (1989): 300 .

${ }^{159}$ Ober (1989): 300.
} 
operated within an environment of a sovereign dêmos, affected by the rule of law. Although Athens had established a form of legal recognition, it only validated laws. The use of laws was open for debate and those who had the most at stake on a given interpretation of a law led the debate. Juries then made decisions according to their acceptance of stated propositions of interpretation of nomoi, both as law and as custom. The justice of the dikastêria ultimately lay in the eye of the beholder.

The emergence of dêmokratia in Athens came after a long process of political change that began at the end of the Archaic Age. Solon implemented important changes to the constitution according to the principle of eunomia, and in the process set up the graphe and ho boulomenos prosecution of crimes that notionally affected the entire body politic giving citizens the ability to prosecute another for a crime against the polis. Later, and after considerable factional dispute, Cleisthenes reformed the tribal divisions of Attica around the principle of isonomia. Under isonomia, all would have recourse to the law, and all would be subject to the law. Power over the law was largely vested in the dêmos, which leads scholars such as Ober to conclude that he established dêmokratia with his reforms. However, only with the reforms of Ephialtes did the dêmos achieve authority over all political and legal issues, as Ostwald, Raaflaub, Rhodes, and others conclude. Hence, the necessary and sufficient dispersal of power among the citizen group is finally evident for the dêmokratia to take shape. Once fully established, dêmokratia grew 
enormously in power, and increasingly sought its own interests. In time, traditional elites then had to seek protection from what became, in effect, a tyrant. Through asserting the value of having recourse to the law, elites helped establish the rule of law as the ultimate restraint on the excessively powerful dêmos. Based on the patrios politeia and the law code of the late fifth century, the rule of law was the only legitimate restraint on the demos, as law was the creation of the dêmos. However, exactly what Athenians meant by references to the rule of law was yet undefined. The important point was simply that the law upheld isonomia within the dêmokratia, and maintained security of the constitution through eunomia. The rule of law emerged as a necessary condition for stable Athenian dêmokratia, and then became a topos by which litigants in the dikasteria could base claims to justice at the hands of the Athenian dêmos. 


\section{Chapter 3}

\section{The Rule of Law in the Fourth-Century Dikastêria}

The emergence of the demagogues in the latter half of the fifth century left a legacy that prevailed in Athens. The power of the demagogues lay in their ability to speak to the dêmos in its own terms, persuading them toward an often-withheld agenda. Power devolved from the traditional landed aristocratic elites to a class that often found its economic basis in the market economy and turned away from old familial ties as a source of political power. Political bonds between leaders and followers formed from activity in the dikastêria, in which demagogues proved themselves highly effective. Notwithstanding individuals' power to persuade, the demos further entrenched its control of the dikastêria and ekklêsia through the ability to interpret laws and adjudicate disputes. Problematic in the idea of demotic power was the amorphous nature of the dêmos as a political body. Individual citizens could separate themselves from unsuccessful or unpopular outcomes (Thuc. 8.1.1; Xen. Ath. Pol. 2.17), and often sectors of the dêmos opposed decisions throughout the decision making process. Consequently, who made up the dêmos becomes uncertain. That very uncertainty, however, allowed the demagogues, and those who followed in their tracks, to take a degree of control over the decision making process. Although based on legal processes, legal disputes could involve a considerable amount of non-legal discussion. For Athenians, however, such issues remained integral parts of the legal process. Litigants may choose to 
portray their opponent as ponêros, hybristês, or even tyrannos in a bid to highlight incompatibility with Athenian nomos. With the fourth century reliance on the patrios politeia, and the view of the old laws as of high value, the unwritten law maintained a strong influence on Athenian legal thought. As a result, the application of law in the dikasterria came to be as much about the alignment of behaviour with the core values of Athenian dêmokratia as it was about the letter of the law. Nevertheless, orators upheld the letter of the law strongly in their speeches. In doing so, orators frequently drew on the language of the rule of law. However, in the actual application of the law, custom remained a factor. Character assaults became a valid tactic in showing a person's inability to live within the agreed framework of the Athenian society, and thereby their inconsistency with the imagined community of the traditional dêmokratia. ${ }^{160}$ Consequently, the ability of orators in the Athenian dikastêria to speak gave them the power to offer their idea of the Athenian community to the jury to decide upon. In framing their ideals, orators helped to construct the identity of Athens as a polis, and of Athenians as a people. In asserting the rule of law, litigants asserted nomos as the security of the dêmokratia and proved the legitimacy of its existence. However, in using legal process to attack fellow citizens, orators used the rule of law and demokratia to exclude opponents from the political dialogue, thus attempting to secure their own place as politically powerful Athenians.

\footnotetext{
${ }^{160}$ On the concept of "imagined communities", see Anderson (2006).
} 
At the beginning of the fourth century, there remained a degree of fluidity in political and legal terminology despite the emergence of a legal code. There was also a degree of agreement between factions that dêmokratia should continue. The dêmos had proven its ability to unite against oppressive rulers. The revolution of 404/3 BC led to tyranny and slaughter, possibly of as many as 1500 citizens, and ended in a bitter stasis to which no one wanted to return. ${ }^{161}$ Hence, oligarchs ceded the possibility of taking the greater share of power in Athens. However, the dêmos had shown its ability to act arbitrarily and contrary to the law, which gave oligarchs some bargaining power in the post revolution reconciliation. An amnesty ensured the polis could return to its proper business, and Lysias argues that it was the amnesty that brought unity from stasis by abandoning the wholesale pursuit of vengeance (Lys. 2.63-5). ${ }^{162}$ The legal code finally drafted in $399 \mathrm{BC}$ gave the dêmos legitimate legal powers and duties. Athenians wanted to avoid another round of political turmoil such as had resulted from the Peloponnesian War. ${ }^{163}$ Under the dêmokratia of the fourth century, aristocrats no longer had undue power due purely to their birth, but neither could the dêmos purge the ranks of nobility without good cause and due deliberation. Importantly, the dêmos had settled the long-standing discussion of the patrios politeia. Under the fourth-century dêmokratia, patrios politeia was the traditional democracy, and patrioi nomoi were traditional democratic laws. However, the debate continued as to what

\footnotetext{
${ }^{161}$ Hansen (1991): 42.

${ }^{162}$ Quillin (2002) argues that it was in the Athenian citizens' interests to forgo revenge; Wolpert (2002) suggests that the Athenian citizen body splintered so that there were no factions left to continue stasis.

${ }^{163}$ Hansen (1991): 303.
} 
was patrios under the demokratia, and what constituted conventional morality. Hence, the topos of patrios politeia remained as a part of the configuration of the rule of law. If laws were to rule, the dêmos would need to decide what shape the laws would take, and what sources it would draw from.

The authority from tradition was a strong topos in Athenian forensic oratory. Conforming to the Greek ideal that older is better, Athenians perceived the better laws as the earlier laws. Athenian law therefore contained a strong conservative bias. The law code was ostensibly based on the laws of Solon, which gave it a weight of authority that democratic law alone was not able to achieve. Orators, however, rather than referring to a law as part of the law code, constantly drew on Solon as the lawgiver. Hence, thesmos played a continuing role in the demokratia. ${ }^{164}$ Subsequently, the idea of nomos as statute comes under question, as the laws of Solon themselves were of uncertain authenticity and ultimately had more of a customary force within the dêmos. Consequently, law remained a fiction open to interpretation and manipulation by those with sufficient ability to persuade. The partisan nature of the dikasteria then meant that the dêmos would have to decide between two proposals according to its self-defined interests. While the jury kept the ultimate power of decision for the demos, orators maintained a degree of power in that they framed the terms of reference.

The power balance between orator and jury was an important feature of political stability in the fourth century. The dêmos had shown in the past that it was able to survive the stasis inevitable in overcoming oppressive rule, as it

\footnotetext{
${ }^{164}$ See chapter 1 above for a discussion on the development from thesmos to nomos.
} 
had done at the time of Cleisthenes and during the oligarchic revolutions at the end of the fifth century. As Ian Morris states “...when a ruling elite fell apart in disorder, as at Athens in $507 \mathrm{BC}$, democratic institutions were one obvious response. ${ }^{165}$ Although class was a factor, power struggles consisted of more than simple class struggles. Aristocratic elites with land, networks of family friends, and bonds created through military leadership historically held power and ruled with their interests in mind. Dêmokratia, on the other hand, led to an increasing degree of focus on the interests of the dêmos, and demagogues championed demotic self-interest. Aristocratic elites, however, also made up the dêmos. Outnumbered by the plêthos, elites had to use demotic self-interest to their own purpose to maintain power. Consequently, aristocratic elites had largely disappeared from political power by the early fourth century. Elites of the fourth century, although wealthy, drew on their apparent beneficence to, and concern for, the dêmos. Although they continued to assert their aretê, elites identified themselves as having a shared interest in the outcome with the dêmos, while opponents were acting against such interests. Democratic equality based on citizenship was an important value, and the dêmos ensured that no one would again have the opportunity to wield undue power over the dêmos.

The possibility of tyranny in Athens remained a constant fear among the dêmos. The Peisistratid dynasty offered an historical example of tyranny, but Critias and his Thirty offered a more recent and chilling example. By the fourth century, neither oligarchic nor democratic faction was willing to allow

\footnotetext{
${ }^{165}$ Morris (1996): 28.
} 
any individual or group of individuals to take full control of the polis. Protection was therefore necessary to ensure freedom from tyranny remained. During the fifth century, the law of ostracism offered a layer of protection from overly powerful individuals. Any citizen seen as potentially becoming too powerful could be voted out of the polis for ten years at a special assembly with a minimum of 6,000 citizen members. As the century went on, however, ostracism fell into disuse. Such arbitrary exercises of power became inconsistent with dêmokratia. Instead, legal processes evolved that enabled the dêmos to act where it saw power unduly held. Under the law code, laws could not be directed at any one individual unless there was a direct assertion from an ekklêsia of 6,000 (Dem. 23.86; 24.59). However, under a law that protected the existence of the dêmokratia, any citizen could receive great honours for killing a tyrant (Andoc. 1.96-8). Where ostracism had previously been a key check on individual political leaders' power, in the fourth century the dêmos used the dikastêria, relying particularly on actions such as the graphê paranomôn or hybris. ${ }^{166}$

In as much as it was open to individual citizens to take a legal action to court themselves, it was also open to them to select the type of action they would take. Demosthenes outlines the possible avenues that "Solon" laid down for citizens to achieve justice for a wrong, stating citizens' varied abilities required the existence of "many routes through the laws" (Dem. 24.25-7). ${ }^{167}$ Each course could be chosen according to its risk, but each one had the

\footnotetext{
${ }^{166}$ Hansen (1991): 205. See, for example, Lys.6.8.

${ }^{167}$ On the range of procedures open to citizens through the courts, see Todd (1993): 98-122.
} 
potential to protect a citizen and uphold their right to recourse to the law. Hyperides supports the idea of a variety of actions, but disagrees with the place of choice (Hyp. 3.4-6). For Hyperides, the law prescribes which particular action or procedure to take. Both models uphold the law as the basis of legal actions. However, whereas Demosthenes' model is fluid and leaves open the ability of the citizens to take action according to their physical, intellectual, social, or political power and ability, Hyperides' model upholds the dêmos as the legitimate body to judge legal cases. Demosthenes, in his action Against Meidias, makes use of this fluidity in an argument on the private versus public nature of particular actions (Dem. 21.25-26). Demosthenes highlights the ability to choose an action, and shows his reason for his particular choice. Taking a public case allows Demosthenes to parade the topos of the citizen-protector, the prostatês tou dêmou. However, there were many instances where a citizen had no choice of action. For example, illegal proposals could only be challenged by graphê paranomôn or graphê mê epitêdeion theinai, and a foreigner pretending at being a citizen could only be prosecuted by graphê xenias. ${ }^{168}$ Further, a citizen may be limited to certain actions by their social standing, age, or experience in the courts, as Ariston claims in his action against Conon (Dem. 54.1). ${ }^{169}$ While Athenian law allowed a variety of actions, it was up to a citizen to gain the ability to pursue any given course of law through the courts. The rule of law then lay in the existence of valid legal procedures to affect justice.

\footnotetext{
${ }^{168}$ Carey (2004): 114.

${ }^{169}$ Lanni (1999): 33.
} 
The ability of legal process to have a limiting effect on power within the polis shows the power of the dikasteria, and the place of the rule of law. Under the demokratia nomos was, in the first instance, the decision of the combined dêmos. The jury then decided according to the law as proposed in the dikastêria (Dem. 19.179). Dêmokratia was rule of the people according to the law, not temperaments (Aesch. 1.4, 3.6). ${ }^{170}$ Equality of citizenship was assumed, ${ }^{171}$ even on questions of honour (for example, see Dem. 51.1-2; Aesch. 1.129). Hence, all citizens were expected to conform to the law, and it was no longer necessary to draw directly on the ideal of isonomia. Excess power was a potentially corruptive influence on the polis, and the holder of such power was a genuine threat to the citizen body. In ensuring no individual could gather too much power, therefore, the dêmos was asserting its laws and its own power over that of the individual. ${ }^{172}$ The idea of the tyrant remained a useful rallying call, though no evidence exists for a genuine attempt at tyranny after Critias. In asserting the force of law in the dêmokratia, the dêmos ultimately conformed to the expectations of the rule of law. Isonomia, which had previously been about political equality, became equality under the law; a principle of one law for all. How the idea of the rule of law actually plays out in the dikastêria is, therefore, highly relevant.

Magistrates were under the legal obligation in the fourth century to ignore unwritten law (Andoc. 1.87). Lysias argues that an order from a magistrate that contravenes a nomos should be ignored (Lys. 22.6-10.).

\footnotetext{
${ }^{170}$ Rosenbloom (2001): 58.

${ }^{171}$ Cartledge (1996): 179.

${ }^{172}$ Raaflaub (1996): 142.
} 
Likewise, jurors in the dikastêria were under oath to vote "in accord with the laws and decrees of the Assembly and the Council of Five Hundred" (Dem. 19.179). However, jurors also had the ability to vote according to their conscience or judgement where no law existed on a matter (Dem. 20.118). Consequently, custom kept a foothold within the democratic rule of law, and in this respect the dikasteria take on the role of the law maker, and become the guardian of the laws (nomophulax) (see Dem. 22.57; 24.36-37; 25.6, 24; Aesch. 1.7; 3.7; Dein. 3.16; Lycurg. 1.3-4), a role the Areopagus, according to tradition, held until the time of Ephialtes (see Arist. Pol. 1274a5-10; Ath. Pol. 25). ${ }^{173}$ In taking on the role of the most highly regarded legal and moral institution (Lys. 3.2), the dikastêria adopted the moral and legal esteem of the position. While magistrates were clearly under the law, the jury could at times be considered over the law (Dem. 24.78; Isoc. 20.22). Demosthenes claims that the dikastêria, due to its ability to affect justice, holds greater authority than even the boulê and the ekklêsia (Dem. 57.56). Further, there was no ability to appeal a decision of the dikasteria (Ant. 5.89), whereas decisions in the boulê and ekklêsia could be questioned in the dikastêria. Consequently, for the rule of law to prevail, it would need to be brought to life through the dikastêria.

Orators of the fourth century regularly praised the rule of law as a cornerstone of good government, and there were some general principles that gave it credence. ${ }^{174}$ Generally speaking, nobody could be punished without a

\footnotetext{
${ }^{173}$ On the Areopagus as nomophulax see Cawkwell (1988).

${ }^{174}$ Cohen (1995): 52.
} 
trial (Aesch. 2.77, 3.235; Ant. 1.47-8; Dem. 39.46; Isoc. 7.67, 20.11; Lys. 22.2), though kakourgoi could be executed summarily if they admitted to the criminal act. Justice must be seen to be done (Lys. 25.35). The punishment should fit the crime (Lys. 12.85; Isoc. 20.6). A citizen could not be tried twice for the same offence (Dem. 20.147). Criminality required a basis in written law (Andoc. 1.87). A statute of limitations existed for some offences (Lys. 13.83). Jury selection by lot protected impartial decision-making (Dem. 25.27), and jury decisions were by secret ballot, protecting the integrity of the vote (Lycurg. 146; Isaeus 5.19). Punishment of offenders had both a deterrent and educative value (Dem. 25.17), and the severity of punishment was more commonly in relation to the immoral or antisocial nature of the offence rather than its severity in criminal terms (Lycurg. 65-6). Irrespective of particular orators' take on what the rule of law entailed, there were sufficient mechanisms to establish the rule of law as a set of procedural norms within the Athenian legal system.

Despite the existence of legal principles, it is a widely noted point that Athenian legal disputes leaned more often toward personal attack than to arguments of interpretation of statutes or legal doctrine. ${ }^{175}$ It would be easy to assume that such argumentation falls into irrelevant subjectivity and undermines the validity of Athenian legal dispute (see Lys. 3.46; Isoc. 7.33-4; Dem. 23.206; Plato. Gorgias 454b-e). However, character was an important

\footnotetext{
${ }^{175}$ Cohen (1995): 61; Lysias (10.7) argues against strict interpretation, arguing that if a word is banned from use, so should all of its synonyms.
} 
feature of litigation, particularly as a reflection of Athenian values. ${ }^{176}$ Aristotle, in the Rhetoric, suggests value-based topoi that orators should use to persuade. A speech should rely on three proofs, the character (ethos) of the speaker, the ability to create sympathy in the listener, and the quality of persuasion in the speech itself (1.2.3). Aristotle recommends speakers make their moral purpose clear in the narrative, for "as the moral purpose, so is the character" (3.16.8). More important for forensic oratory, however, is the ability to dispose the hearer toward their argument

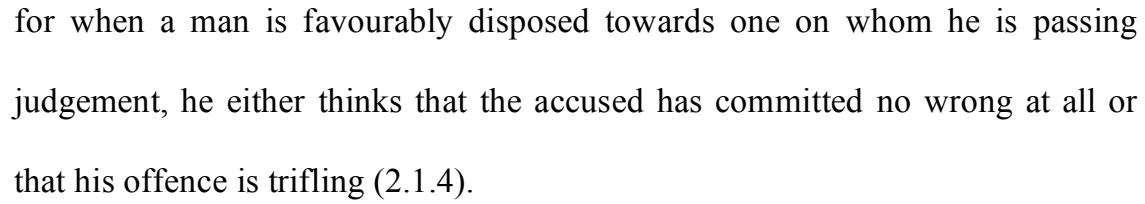

For this purpose, the use of emotion is necessary (3.7.6), and speeches must conform to the character of the constitution in which it is made (2.18.1). A clear example is in Lysias, where he asks the jury to "hate the criminal before the trial", and in doing so ensure the administration of the constitution (dêmokratia) according to the law (30.35). The use of character assessment helped orators to establish credibility, trust, and affinity with jurors. ${ }^{177}$ It also offers a litigant the opportunity to make a comparison between laws and lawmakers. ${ }^{178}$ In highlighting the characters of the opposing litigants, each tried to show their own character as chrêstos and consistent with the dêmokratia while the other was poneros and potentially responsible for the subversion of dêmokratia, most commonly through the disregard for its laws.

\footnotetext{
${ }^{176}$ See de Brauw (2002).

${ }_{177}$ Carey (1994): 34-5.

${ }^{178}$ De Brauw (2002): 169.
} 
A further effect of the ostensibly irrelevant arguments is that they provide a social context for the dispute. Lanni argues that the Athenians were sufficiently sophisticated to develop a concept of the rule of law, but that they valued equity concerning particular cases over consistency and the detailed formulation of general legal principles. ${ }^{179}$ Aristotle states clearly, "that which is equitable is just, and equity is justice that goes beyond the written law" (Rhet. 1.13.13). Although there was a need for cases to find their basis in written law, many law court speeches fail even to mention a law, and no mechanism existed to check orators' use of laws. ${ }^{180}$ Orators avoid an over reliance on legal reasoning, and this may be due to the continuing connection between nomos and the interest of the demos. Athenian law could not exist in an abstracted form, so could not be truly relied upon to provide a purely legal framework for the courts to operate within. Further, the lack of appeal mechanisms meant that the only check on the jury was the social pressure exerted on individual members after the trial (see Dem. 25.98). ${ }^{181}$ Athenian laws tended to prescribe legal procedures rather than define offences, which is to say, they focussed on procedural more than substantive law. ${ }^{182}$ Even where Demosthenes 54 argues the importance of the action against slander (dikê kakêgorias) as a protection against violence and murder, the progression of actions is based on procedural issues rather than substantive ones (Dem. 54.17-

\footnotetext{
${ }^{179}$ Lanni (1999): 28-9, 32.

${ }^{180}$ Lanni (1999): 30-1.

${ }^{181}$ See Lanni (1997) on the potential effect of spectators on jury decisions.

${ }^{182}$ Carey (1996): 38; Hansen (1975): 10, 21.
} 
19). ${ }^{183}$ Consequently, custom and tradition played a continuing role in the interpretation of law and the jury remained a decision maker with considerable discretion and power over the course of legal disputes. To a considerable degree, therefore, Athenian rule of law relied on the power of the jury to adjudicate.

One of the key decisions a jury would have to make in adjudicating is on the effect of previous decisions. Athenian dikastêria did not operate according to a doctrine of binding precedent, and nor were jury decisions open to appeal. ${ }^{184}$ However, there are many instances of orators referring to earlier decisions, particularly on the issue of deterrence. ${ }^{185}$ Inherent in the idea of the jury decision as a deterrent is that future juries will look at the decision and follow it. However, as Lanni notes, the use of deterrence refers to the effect of a decision on future criminals rather than future juries. ${ }^{186}$ Arguments to deterrence generally precede calls for severe punishment, which suggests that deterrence is a topos to elevate a litigant's desire for punishment. Punishment, deterrence, and education, go hand in hand in Athenian legal conception.

Precedent, however, may not be linked directly with deterrence, and litigants do refer to earlier court decisions. ${ }^{187}$ Andocides, in a speech to the ekklêsia, encourages Athens to "use the past as evidence for the future" (Andoc. 3.2). However, references to earlier decisions could only be achieved

\footnotetext{
${ }^{183}$ Todd (1993): 268-71.

${ }^{184}$ See Ant. 2.3.11; Aesch. 1.192; Lys. 1.36, 47; 12.35, 85; 14.12; 22.21; 27.7; 30.23; Dem. $34.50 ; 50.64 ; 54.43 ; 56.48 ; 59.77,112$; Lanni (1999): 41.

${ }^{185}$ Laani (1999): 42.

${ }^{186}$ Lanni (1999): 43.

${ }^{187}$ See Aesch. 1.86-8, 173; 2.6; 3.252-3, 258; Andoc. 1.29-30; Ant. 5.67; Din. 1.13, 23; 2.14, 25; 3.17; Dem. 21.6, 175-84; 24.138; 19.273; 20.146-8; 34.50; 59.116-7; Hyp. 4.1-3, 33-4; Lycurg. 1.52ff, 111-16; Lys. 5.5; 12.35ff; 13.56-7; 6.17; 22.16; Laani (1999): 46.
} 
through memory of the case. Although orators in the fourth century increasingly moved from relying on oral statements to providing written evidence, jury decisions were not recorded. ${ }^{188}$ Such references do not formulate legal principles from the cases, and do not argue the case by close analogy, as modern use of precedent would. ${ }^{189}$ Rather, orators use earlier decisions casually in a manner to persuade the jury toward their argument. The opponent is a bad Athenian, and should be punished like other bad Athenians, even if he has been a good Athenian most his life. Doing so upholds the esteem of the dikasteria, and the rule of law with its links to the patrios politeia. Consequently, the idea of precedent, a mainstay in many well articulated rule of law theories, acts as a rhetorical device to have an opponent more harshly penalised.

Despite the insistence on written law, non-written law remained a factor. Pericles had stated in his funeral oration that the unwritten laws bring about informal sanctions (Thuc. 2.37.3). Lysias (6.10) draws directly on Pericles, stating that people must obey both written and unwritten laws. Aristotle (Rhet. 1.13.12-15) follows a similar proposition in associating unwritten justice with non-judicial punishment, and recommends the use of koinos nomos where a law acts against the interests of an orator (Rhet. 1.15.1-6). In such a case, it is appropriate to base arguments on epieikeia ("noble fairness"), equity, and justice. ${ }^{190}$ Justice was an ideal upheld by Greeks generally, and showing a nomos as consistent with universal values could heighten an orator's argument

\footnotetext{
${ }^{188}$ Lanni (2004): 164; Rhodes (1980): 315.

${ }^{189}$ Lanni (2004): 160-1.

${ }^{190}$ Carey (1996): 36.
} 
on the law. For example, Lysias (1.2) refers to moicheia as a universal Greek crime, unacceptable to both oligarchs and democrats, and punished in the same way in both systems, seeking to give his argument more weight. More fundamentally, Lysias refers to the educative and deterrent functions of law when he asks the jury to "encourage the others to behave justly" (27.6). Behaving justly translates to obedience to nomos, and draws on the customary practices of Athenian tradition.

The standard Greek conception of justice was one by which justice requires a person to harm his enemies and help his friends (Plato. Republic. 332d-335c; Lys. 9.14). ${ }^{191}$ Justice is one of the key virtues of Athenian society, ${ }^{192}$ and administration of justice is the fundamental aspect of Athenian law. ${ }^{193}$ Aristotle claims that vengeance upon an enemy is just and therefore nobler than agreeing to terms (Rhetoric. 1.9.24). However, vengeance should not be pursued to excess (Rhetoric. 1.10.4), as voluntarily causing harm contrary to the law is unjust (Rhetoric. 1.10.3). Under the rule of law, the legitimate vehicle for taking retribution upon an enemy was the dikastêria, which gave the dêmos the ability to decide the outcome of disputes (Lys. 13.1, 46). ${ }^{194}$ Thus, litigation became a form of agon, by which there would be a winner, who gains time and a form of defensive social power, and a loser. ${ }^{195}$ Legal and political equality could therefore become a tool for asserting social dominance. The dikastêria became one of the loci of power consistent with

\footnotetext{
${ }^{191}$ Cohen (1995): 66.

192 Lanni (2006): 27.

${ }^{193}$ Hansen (1975): 21.

${ }^{194}$ Cohen (1995): 71-2.

${ }^{195}$ Cohen (1995): 67.
} 
Ober's discursive paradigm, ${ }^{196}$ and offer a venue for dispute resolution and the competing for honours at the hands of the dêmos in which the dêmos decides on the merits of given competing values. Athenian elites therefore looked to the dêmos to arbitrate their disputes to avoid outbreaks of stasis.

The place of the dêmos-jury as the conferrer of timê gives weight to Cohen's theory that the Athenian dikastêria were the decisive body for deciding on issues of vengeance and personal enmity. ${ }^{197}$ Cohen bases his claims not only on the explicit reference to existing enmity, but on denials of enmity. Carey refers to such denials as the establishment of goodwill by the "neutralisation of any hostility against the speaker" ${ }^{198}$ For example in Lysias 1, Euphiletus, an alleged aggressor, claims justifiable homicide on the basis that he found Eratosthenes engaged in an act of adultery with his wife. The defence requires Euphiletus to prove that the killing was not premeditated. $\mathrm{He}$ claims that the adultery was the only source of enmity $(1.4,43)$ to prove a lack of pre-existing personal enmity and allay the suspicion of premeditation or entrapment. In Lysias 24, as a defendant, the speaker argues against the existence of enmity to suggest that the accuser is a sykophant (24.2). Lack of a pre-existing personal motive showed obedience and conformity to the laws of the polis, and respect for the dêmokratia. However, lack of enmity could lead to the suspicion of sycophancy, and it was often appropriate to declare existing enmity.

\footnotetext{
${ }^{196}$ Ober (1989): 88-90; see above, p17.

${ }^{197}$ Cohen (1995): 72, 105; Dem. 54.16; 58.1-, 58-9.

${ }^{198}$ Carey (1994): 28.
} 
To an extent, the declaration of enmity comes under Aristotle's suggestion of stating the moral purpose. Lysias (12.2) hints at his enmity with the accused, but suggests an even stronger enmity between the accused and the polis. In another case, Lysias refers to the enmity between the speaker's father and Alcibiades' father (Ly. 14. 2). The litigant in such a situation acts as a watchdog, upholding the laws and protecting the polis from enemies. Antiphon's client seeks to "take refuge" in the dikastêria and justice (1.4). Further, the jury adopts a religious function in purifying the city by eliminating accursed citizens ([Lys.] 6.53). Demosthenes pursues a similar argument against Meidias (Dem. 21.13-20). Again, Lysias 10-11 show that, although there is enmity between the speaker and Theomnestus, the reason for taking the case is the effect of slander on his client's father and its corresponding threat to Athenian values (10.2-3). The case of Dem. 18/Aesch. 3 involves the most explicit examples of personal enmity within a legal dispute. Demosthenes $(18.12,15)$ states outright that Aeschines is pursuing personal enmity in taking the case, and that the case should not be in the court (18.123-6). Aeschines is taking a case contrary to the laws, and is therefore acting unjustly. Demosthenes, alternatively, acts to protect the polis (18.281). Aeschines engages in outright insult of Demosthenes (3.51-3, 76-8, 162, 171-6, 212), to which Demosthenes responds (18. 258-62). Such arguments and insults appear contrary to proper legal process under the rule of law. However, the fourthcentury Athenian conception of law is important in understanding such invective. 
In behaving dishonourably and unjustly, a citizen acts contrary to the character of the imagined community. The nomoi are the expressed decisions of the community, and acting against the nomoi of the polis is an act against its values. Nomoi constitute the character of dêmokratia (Dem. 24.138), and protect the polis and its people (Dem. 24.156; 25.21-22; Aesch. 1.4-5; 3.6, 169, 196). ${ }^{199}$ For the laws to rule and protect the polis and its citizens people must uphold not only the laws themselves but also their underlying values. Hence, Aristotle's preference in the Rhetoric for unwritten laws becomes pertinent. The authority closest to unwritten law was the historical authority of the Solonian code and Athenian morals. Thesmoi, with their ancient roots and moral flavour were held up as of great value because of this. Law was never separated from morality or the interests of the demos. ${ }^{200}$ Consequently, the rule of law entailed not only the letter of the law, but also historical and moral authority. A citizen who wanted to be seen as upholding the law would need to show their concord with the character of the demos as expressed through its laws and legal decisions. ${ }^{201}$ Consequently, an orator needed to find a balance of all the competing factors to prove an opponent's behaviour as contrary to the laws.

Pseudo-Andocides provides a good example of the balance orators have to find in the courts. ${ }^{202} \mathrm{He}$ portrays himself as the dêmos' loyal friend and benefactor who upholds Athenian laws and democratic legal process (4.8-9,

\footnotetext{
${ }^{199}$ Rosenbloom (2001): 45; De Brauw (2002): 173.

${ }^{200}$ Ober (1989): 147.

${ }^{201}$ De Brauw (2002): 168.

${ }^{202}$ Thanks to Dr David Rosenbloom for use of his unpublished commentary on [Andocides] 4.
} 
19, 36-8, 40, 42). ${ }^{203}$ He criticises the dêmokratia (4. 3-6, 9, 12, 21, 23, 27 32, 38), but also upholds it $(4.8,13,16,27,33,35,40 ; 3.1-10,41) .{ }^{204}$ By contrast, Alcibiades benefits from acting contrary to the law and Athenian interests (4.11-12, 25-31), uses his natural power against those who would hold him accountable to the law $(4.18,30-31,35-6)$, and is ultimately tyrannical $(4.10$, 13-21, 24, 27). The speech acts as a paradigm of two elites competing for power through legal process. Although in this instance the procedure was an imagined fifth-century ostracism, the process of argumentation flows through into the dikastêria of the fourth century, and the balance of factors remains a constant feature in forensic oratory.

Among various orators, there was much divergence in what the rule of law meant. For Aristotle, the rule of law was a protection from the power of the dêmos, and gave magistrates broad ranging powers of discretion. ${ }^{205}$ Aristotle stresses the need for law where he says that, "where the laws do not rule there is no politeia" (1292a31). For a regime to be valid, the rule of law must operate, and the offices ought to judge (1292a32). Dêmokratia run by decree, therefore, is not a constitutional dêmokratia (1292a36), but is susceptible to the influence of demagogues and acts as a tyrant. ${ }^{206}$ The rule of law is the salvation of citizens from the outright licence that unrestrained rule promotes (1310a30-5). The rule of law ultimately provides dêmokratia with

\footnotetext{
${ }^{203}$ Rosenbloom (2001): 9.

${ }^{204}$ Rosenbloom (2001): 9, 68.

${ }^{205}$ Cohen (1995): 35.

${ }^{206}$ Lintott (1992): 119.
} 
the element of justice. ${ }^{207}$ For Demosthenes, the rule of law preserves the city (25.11), and is responsible for its prosperity (24.5). A key distinction between oligarchy and dêmokratia is that democrats live under the law, while oligarchs view themselves as above the law (24.75-6), a sentiment supported by Aeschines (1.5). Obedience to the laws upholds and protects democratic freedoms. ${ }^{208}$ The rule of law rules over every aspect of life in the dêmokratia and without it, men live like wild beasts (Dem. 25.20). ${ }^{209}$ The rule of law, therefore, protects not licence but the liberty to live as one pleases; eleutheria. ${ }^{210}$ The ability to live as one pleases became another common topos, by which orators attempted to show that their concept of political ideology provided the most freedom (see Dem. 22.51; Lys. 25.33; Isoc. 12.131, 7.20; also Arist. Pol. 1310a28-32, 1317b10-12). As Lysias states, "the greatest harmony is for everybody to be free" (2.18). For its proponents, the rule of law ultimately upholds Athenian eleutheria.

Fundamental to the rule of law are legal principles that guarantee legal certainty and freedom from unwarranted interference by official institutions. In Athens, a number of such principles existed. However, the nomoi of the dêmokratia owed as much to historical and traditional customs as they did to any desire for authoritative statute law. Nomos as law was never fully separated form nomos as custom, so litigants in the dikastêria were able to

\footnotetext{
${ }^{207}$ Kraut (2002): 115n

${ }^{208}$ Cohen (1995): 52.

${ }^{209}$ Harris (1992): 161.

${ }^{210}$ Cohen (1995): 54.
} 
draw heavily on socio/political concepts in constructing their legal arguments. Consequently, speeches became as much about the character of the opponent as they were about proving their criminal behaviour, and perhaps even more so. Despite the need for crimes to find their basis in law, Athenians pursued opponents ruthlessly through legal procedures. Rather than being irrelevant sidetracks, personal attacks remained an essential part of legal speeches. While nomoi were laws, the place of custom and morality never completely disappeared leaving the Athenian idea of nomos open to interpretation. The Athenian dêmos saw nomos as an expression of its democratic character, and expected citizens to uphold its values as much as its laws. Consequently, the rule of law plays a varied role within the Athenian legal process. On the one hand, it is a way to identify and establish important legal principles and hold officials and citizens accountable to known standards. On the other, it is a way for citizens with sufficient oratorical ability to overpower political opponents through the open agon of litigation. Fundamental to the use of nomos in such a way was the conceptual uncertainty that remained at the core of the perception of what nomos was. While there are clearly identifiable rules of law within forensic speeches, the place of the dikasteria as an avenue for the pursuit of personal enmity remained. Rule of law, ultimately, was a topos by which orators could both establish themselves as legitimate power holders, and discredit their opponents through the fiction of law in the dikastêria. 


\section{Chapter 4}

\section{Law and the Character of the Dêmos: Demosthenes 20, Against Leptines}

The case of Demosthenes Against Leptines deals with the issue of liturgies and the ability of the dêmos to reward benefactors with immunity for their performance, or ateleia. With a shortfall in the number of citizens able to perform liturgies during the fourth century, Leptines introduced a nomos to void all ateleia and restore the city to its full capacity. However, Demosthenes takes the view that to do so not only dishonours Athens, but also rewards selfishness rather than promoting honour. To remove the ability of the dêmos to offer rewards places an invalid restraint on the sovereignty of the dêmos, and suggests a character more in line with tyranny or oligarchy rather than dêmokratia. By taking a graphê mê epitêdeion theinai, Demosthenes demands that the dêmos rethinks its position on the nomos. In doing so Demosthenes questions the sovereignty of the dêmos by overturning one of its nomoi, but in the process also upholds the power of the demos by respecting its formal procedures and getting the dêmos to question its own motivation rather than simply having the nomos abolished outright. Fundamental to the process is the legality of Leptines' nomos, which Demosthenes shows clearly to be contrary to existing laws and procedures of law making. Further, the law overturns long held traditions such as the inalienability of patrimony. However, equally important is Demosthenes' moral conception, which he uses to show that the jury have no option but to overturn Leptines' nomos in favour of his own. In a 
bid to undermine the legal perspective of his political opponents, Demosthenes uses the graphê mê epitedeion theinai to assert the force of the rule of law as a valid check on the sovereign lawmaking powers of the dêmos.

Demosthenes 20, Against Leptines, relates directly to the institution of liturgies and the dêmos' ability to bestow honour by way of immunity from them. A liturgy involved the assignment of financial sponsorship for events such as equipping and maintaining warships, or equipping and training choruses for dramatic festivals, to wealthy citizens and metics on a yearly basis. ${ }^{211}$ In a state that lacked regularised formal taxation, liturgies acted as a form of economic redistribution. ${ }^{212}$ In doing so, Athens created a mechanism to "ameliorate the extent of citizen destitution", and to prevent economically based political uprisings. ${ }^{213}$ Further, liturgies bolstered the state against both internal and external pressures. ${ }^{214}$ Although heavily obligated to perform liturgies, wealthy Athenians could find relief through either immunity (ateleia) or antidosis. ${ }^{215}$ After the Social War of 357-55 BC, the Athenian dêmos found it difficult to find people to perform liturgies. ${ }^{216}$ Leptines proposed a law that sought to address the problem by revoking all immunities granted in the past, and ensured they could no longer be granted in the future. ${ }^{217}$ The exception to the law was the descendents of the tyrant slayers, Harmodius and Aristogeiton

\footnotetext{
${ }^{211}$ Ostwald, (1995): 370.

${ }^{212}$ Ostwald (1995): 368.

${ }^{213}$ Ober (1989): 202; see also Aristotle, Politics, 1320a35-b17.

${ }^{214}$ Ober (1989): 200.

${ }^{215}$ Christ (1990): 149-150; Todd (1993): 120.

${ }^{216}$ Vince (1962): 488.

${ }^{217}$ Vince (1962): 488.
} 
$[20.18 ; 29 ; 70 ; 127 ; 128 ; 159 ; 160]$. A group of individuals brought a graphê mê epitêdeion theinai against Leptines' law in a bid to have it overturned.

The graphê mê epitêdeion theinai was the companion to the graphê paranomôn. While the graphê paranomôn dealt with illegal proposals in the form of psêphismata, the graphê mê epitêdeion theinai related to illegally proposed nomoi. The key fact was whether the proposal conflicted with an already existing law. The intent of such a procedure was to establish a form of check on the law making process, which came under the influence of the demagogues at the end of the fifth century. Graphê mê epitêdeion theinai sought to uphold the strength of law, and to help give Athenian laws some consistency. By punishing the individual proposer, the action makes proposers consider carefully what they will propose, and in doing so acts as a strong form of democratic accountability. By taking a graphê mê epitêdeion theinai, a litigant could uphold the rule of law, where "law" refers to established law. However, in upholding established law it also encouraged a conservative bias that finds comfort in the patrios politeia and its strong links with traditional Athenian custom. Consequently, the graphê mê epitêdeion theinai, though established as a democratic procedure, allows the introduction of arguments toward tradition and the very character of the dêmokratia.

One of the notable features of Against Leptines is the lack of outright personal attack often central to law court speeches. Because a year had passed since the law was proposed, Demosthenes could not prosecute Leptines, 
leaving him to focus only on the law $(20.144-145) .{ }^{218}$ The case therefore came before the court on a question of legality. Nevertheless, Demosthenes' argument deals heavily with the character of the law in a bid to expose the character of the proposer by analogy.

At the outset, Demosthenes declares his motivation for taking the case. First, he has a formal reason, in that he thinks the state will benefit from the rescission of the law; second, he has an informal reason, in that he sympathises with Ctesippus whose father Chabrias, a celebrated Athenian general, received ateleia before his death (20.1). Demosthenes follows a common theme of showing that, while a citizen may have a legally valid reason for taking a case, they also have a particular interest in it, which shows they are not simply of a litigious nature or a malicious prosecutor (sykophant). The main strain of the argument then focuses on the character of the law and its relation to Athenian character.

Demosthenes' general opposition to Leptines' law has two bases. First, "no one shall be exempt" takes away honours not only from those who have had them bestowed, but also from those who will inherit, or have inherited, them (20.2). Abuse of a right in itself should not be reason to remove the right, or else the entire constitution would require revocation, as "...there is no single right which has not been abused..." (20.3). However, if the dêmos has been misled, then those who misled it should suffer, and the rights and powers of the wider dêmos should remain intact (20.4). Demosthenes argues that the Athenian ancestors desired honour more than money, which is evident in the

\footnotetext{
${ }^{218}$ Vince (1962): 489
} 
way that Athenians have always willingly spent their money in order to increase their honour (20.10). However, Leptines' law discredits Athenian honour by making it appear envious, faithless, and ungrateful. Essentially, the removal of ateleia is a serious breach of the reciprocal gift-giving relationship of charis, the basis for institutional liturgies. ${ }^{219}$

As a value with ancient roots, charis was part of the traditional Hellenic mode of operation and Pericles based the city's imperial rule on, among other things, the ideal of charis. ${ }^{220}$ The question of charis appears explicitly in Demosthenes' portrayal of the relationship with Leucon, king of the Bosporus. Athens relied heavily on imports of grain, most particularly those from the Bosporus region. Due to the amount of grain that went to Athens, Leucon exempted Athenian grain ships from duties (20.31). In return, Athens bestowed ateleia upon Leucon. Demosthenes argues that, should Athens revoke Leucon's immunity, Leucon will reciprocate by revoking the exemption from duties (20.34). Grain will then leap in price, and Athens will suffer (20.35).

Demosthenes' examples of ateleia recipients are highly problematic. Leucon and Epikerdes are not Athenian, nor do they live there. Leucon (20.29$40)$ is the king of the Bosporus, while Epikerdes (20.41-48) is from Cyrene. As foreigners, they were under no obligation to perform liturgies, and therefore gained no real advantage from their ateleia. The advantage for such recipients is purely honorific. While the intuitive response may be that the removal of

\footnotetext{
219 Johnstone (1999): 100-106.

220 Thucydides 2.40 .4 .
} 
honours reverses the cycle of charis, the actual effect is unlikely to be, for example in Leucon's case, the imposition of a shipping tax. The economic benefits from the grain trade with Athens are sufficient to outweigh the concerns for loss of an honorific gift. Consequently, the use of foreign recipients of honorific decrees seeks to stress the place of honour over money, and support the elite tendency within the speech.

Demosthenes also looks at the position of Athenian recipients of ateleia, though he uses only two examples. Konon (20.68-74), who rebuilt the city walls and the Athenian navy after the Peloponnesian War, and Chabrias (20.75-86), who was a highly successful Athenian general. As wealthy Athenians, both were subject to the performance of liturgies, and therefore gained from ateleia. Demosthenes' argument attempts to show that revoking ateleia harms the demokratia. In fact, the harm he focuses on is harm to traditional aristocratic values. Elites, as the "bearers of a tradition of service to the city" should remain in a special place of honour. ${ }^{221}$ The concern for the dêmokratia is merely a corollary of such a position, as he urges the idea that dishonour of elites reflects poorly on the city $(20.6,8,10,57,63,65,117$, 134ff, 165). Given the connection with tradition, it is not surprising that, despite arguing against the removal of immunities from liturgies, Demosthenes still upholds the value of elites' responsibilities to the city. ${ }^{222}$

Demosthenes describes the Athenian character as

\footnotetext{
${ }^{221}$ Burke (2002): 179.

${ }^{222}$ Burke (2002): 179; see, for example, Demosthenes' speech On the Symmories, in which he argues for an increase in the number listed among the cities wealthiest.
} 
truthful, honest, and where money is concerned, not asking what pays best, but what is the honourable thing to do (20.13).

As proof, he states that the Athenian people paid their share of the Thirty's debt to the Lacedaemonians after the fall of the Thirty (20.11). The responsibility for the debt clearly lay at the feet of the oligarchs, and Demosthenes implies that there was no duty on the dêmokratia to repay it. In choosing to repay the debt, the demokratia showed itself to be noble, and prevented the Lacedaemonians from being able to claim that Athens is dishonourable. However, Demosthenes conveniently sidesteps the fact that the debt would likely have crushed Athens had it lingered, and having recently lost the Peloponnesian War to Sparta, Athens was not in a position to reengage with Sparta over an unpaid debt. Nevertheless, the point of Demosthenes' argument aims to show that Leptines' law is dishonourable, and is therefore inconsistent with Athenian character.

Where the law goes against honour, Demosthenes implies that it looks purely at what pays best, in this case getting people to pay for liturgies. In going against the Athenian character, the law also favours an oligarchic outlook, rather than a democratic one. An oligarchy can make anyone rich instantaneously (20.15). However, under a dêmokratia, glory lies not in flattery but in where speech is free, and he reminds the jury that willing admiration is more highly treasured than a tyrant's gifts (20.16). The effect of the law, then, is that

[t]he law which destroys confidence in the rewards takes away the one thing that gives a higher value to rewards which you bestow (20.17) 
Ultimately, the ideal of charis becomes void and Athens loses timê. Consequently, in revoking immunities, Leptines' law is dishonourable and directly opposes Athenian democratic character.

The emphasis on honour over money and the link with charis creates a connection with ideals outlined by Pericles in his funeral oration. Thucydides reports Pericles stating that Athens bestows favours upon friends generously, and that recipients of such gifts feel the weight of reciprocity (Thucydides 2.40.4). Athens gives fearlessly out of liberality, not expediency (Thucydides 2.40.5). In bestowing honour and gifts freely without fear, Athenians show greater regard for the honour than for the money involved. Further, bestowing of honours is proof of Athens' power (Thucydides 2.41.4). Demosthenes likewise focuses on the honour involved in the case, and tries to show any focus on money as disreputable and contrary to the traditions of Athens. Such focus on money is, in fact, more appropriate to an oligarchy or tyranny.

In referring to oligarchy and tyranny, Demosthenes exposes a possible underlying motive for taking the case. The correlative example for a tyrant's gift comes where Demosthenes refers to the rewards certain cities have expected from Philip (20.63). A number of cities gave information to Philip against other cities out of a desire to receive money, and presumably some degree of protection, from Philip. Correspondingly, Athens could rely on the bestowing of honours to induce enemies to help them. However, Leptines' law removes this ability, and therefore exposes Athens to the danger of reducing its 
ability to protect itself. The danger here is Demosthenes' well-documented view, which proved to be correct, that Philip was seeking to take Athens.

The introduction of the Periclean ideal sheds light on a further motivation behind Demosthenes' speech. Demosthenes shows a desire for the traditional method of law making in Athens. He claims that, in the past, decrees stood as laws and were not regularly altered. However, with the emergence of the new breed of politician in the late fifth century, came a constant desire to change and introduce new laws. The law became chaotic, and the remedy of creating the nomothetae to oversee the introduction of laws proved ineffective (20.91). For Demosthenes, nomoi were no better than decrees, and decrees generally preceded new nomoi (20.92). The implication is that Athens needs less, not more laws. However, the creation of further laws establishes the authority of the dêmos against the traditional elites, who prefer to rely on an unwritten code to which non-elites have little or no access. Nevertheless, Demosthenes proposes a new law to replace that of Leptines, in keeping with established legal practice.

The words of the law proposed to replace Leptines' have not survived. However, Demosthenes refers to its intent when he states that, under it, the deserving will keep their rewards while the undeserving will lose them (20.98). The law accepts Leptines' insistence on the need for more people to perform liturgies, yet still allows an elite group to retain immunity. Worthiness is to be judged on a case-by-case basis, rather than by an all-encompassing law (20.101). In this way, Demosthenes tries to protect ateleia, a class of 
inheritable honours, and guarantee the patrimony of those considered aristoi. In doing so, Demosthenes upholds the traditional ideal of an inalienable patrimony. Nevertheless, the nature of his argument suggests that assuring inheritable ateleia will be good for the dêmos. Such an argument again links back to the Periclean demokratia, in which the moral standing of the dêmos can be judged by the standing and honour bestowed upon the aristoi.

The specific law that Leptines has transgressed is one that deals with procedure, and leads to issues of consistency. To overcome an existing law requires the indictment of it and the introduction of an alternative (20.89). The process ostensibly dates to Solon and ensures that citizens have clear knowledge of the laws that they must obey, and not need to be experts in the law simply to avoid prosecution (20.93-94). The need for consistency in the law is therefore evident. Leptines, however, appears to transgress such consistency. Demosthenes refers to a large number of decrees Leptines' law annuls without going into detail (20.44). However, he later reads an existing law that states, “...all rewards granted by the people shall be valid...", and shows that Leptines' law is inconsistent insomuch as it revokes granted immunities (20.97). Leptines' law, therefore, conflicts with at least one existing law, and the action of graphê mê epitêdeion theinai is proven justified.

The second basis of Demosthenes' objections is that the words "nor shall it be lawful hereafter to grant it" remove the right of the dêmos to bestow honorific rights (20.2). Such a law places under question the power of the 
dêmos, which undermines the ideal of dêmokratia itself. Demosthenes claims that the Athenian dêmos is authoritative (ho dêmos kyrios, 20.107), and states that dêmokratia is guarded by good citizens competing for honours (20.108). To remove the ability of the dêmos to bestow honours lessens the incentives that drive the elite competition for honours, thereby reducing its power to protect itself and maintain its supremacy. Such limitations can only be adopted according to established rules of law, which Leptines has not followed in this case.

The legality of Leptines' law is a major issue in the speech, and Demosthenes deals with questions of procedure and consistency. Leptines' law did not conform to the standard legislative procedure as purportedly set out by Solon (20.93-4). Vince suggests that the procedural error was in Leptines taking the law to the ekklêsia without it going through the nomothetae first. ${ }^{223}$ Demosthenes himself, after outlining the correct procedures, says “...Leptines yonder has observed not one of them..." (20.94). It is difficult to determine whether Leptines followed incorrect procedure. However, Leptines must at least have delivered it to the ekklêsia for it to become law, which gives some weight to Vince. Demosthenes takes the opportunity to attack Leptines through indirect means where he suggests, "those who propose new laws must show themselves ready to obey old laws" (20.153). Leptines, in Demosthenes summation, not only failed to follow correct procedure, but also proved to be disrespectful of Athens' laws, and is therefore a dishonourable citizen.

${ }^{223}$ Vince (1962): 489; see also Hansen (1974): 47-48. 
A further issue of legality relates to a broader treatment of the law in question. Demosthenes shows that Draco, even though he adopted severe punishment for crime, allowed all those convicted their claim to justice (20.158). However, Leptines' law revokes rights without offering those affected the opportunity to gain recompense. In doing so, Athens places more importance on revoking rewards than it does on suppressing murder, and jurors act in contradiction to their oath (20.159). The law therefore encourages dishonourable and unlawful behaviour, and undermines the very constitution it sets out to protect. Consequently, Leptines' law is invalid.

Demosthenes goes on to claim that Leptines' law is irreligious. In preventing Athens from bestowing immunity, Demosthenes claims that Leptines pretends to know the future (20.160). Though he admits that he hopes Athens to be past the need for such expectation, the reality is somewhat different and requires an open mind to potential (20.161). The position leads Demosthenes to claim that the law offends religious sentiment and that "...all things are conditioned by mortality...therefore we must be modest in the day of prosperity, and must show that we are not blind to the future" (20.161-2). Leptines' law is unsound and against Athens' interests (20.163). Offering rewards encourages others to help Athens (20.166). ${ }^{224}$ "If you punish with death those who debase the coinage, I shall be surprised if you lend an ear to men who render our whole state base and counterfeit." (20.167).

Demosthenes makes two important utilitarian objections to Leptines' law. He shows that, while the law may provide thirty men capable of

\footnotetext{
${ }^{224}$ See also 20.5, 103, and 142.
} 
performing liturgies, in doing so it will create distrust in all people (20.22). He then goes on to say that Leptines' law relieves no one, but dishonours the whole State and

therefore, when the damage it will inflict is greater than the benefit it confers, ought it not to be repealed by this court? (20.28)

The argument is one of self-interest, and Demosthenes shows that in allowing the law to exist, Athens ultimately harms itself. Such an argument elevates the jury to the level of guardian of the polis (nomophulax), and supports his later claim that in indicting the law it is the jury as demos that is under scrutiny, rather than the law itself $(20.83) .{ }^{225}$ Demosthenes argues that his legal action aims to protect the greater good of the polis, and the personal enmity involved helps to create a moral force to uphold.

Demosthenes makes an important public versus private distinction in his speech. The removal of rewards is churlish and grudging, and implies that those who received them did not deserve them (20.56). The corollary is that the decisions to bestow the rewards relied on opinion, which can waver, rather than fact, which can withstand scrutiny. In private life, people make many decisions based on convention or opinion, whereas in public life decisions need to have a fact-based assessment (20.57). To allow the revocation of honours places Athens in a position whereby it will accept favours without proper scrutiny, placing it in the debt of people over whom it should maintain ascendancy. Under Demosthenes' argument, Leptines' law reverses the

\footnotetext{
${ }^{225}$ Hansen (1974): 18 refers to the jurors in this respect as the "protectors of the democracy", citing Aesch. 3.235; Deinarchus 3.16. Dem. 13.16; 24.2.
} 
public/private distinction and undermines the traditional ideals upon which Athenian society bases itself.

Demosthenes also turns his attention to the truthfulness of Leptines' argument for his law. Leptines will argue that, with so many wealthy in possession of immunity, the liturgies fall upon the poor to perform whereas his law returns the liturgies to the wealthy who can afford them (20.18). However, Demosthenes shows that "those whose wealth is insufficient necessarily enjoy exemption and are out of reach of this tax;" (20.19). Leptines' law will therefore have no effect on the poorer members of the community (20.20), who make up the largest number of jury members to whom Demosthenes speaks. Demosthenes therefore diverts the attention of the jury from the potentially deceiving fallacious argument of Leptines. ${ }^{226}$

Demosthenes discusses the idea of legal principles, and refers specifically to two, stating that

Where there are no statutes to guide you, you are sworn to decide according to the best of your judgement... Then you must apply these principles to the law as a whole. (20.118)

Such a concept is a guiding principle for jurists that would fit comfortably with the concept of the Common Law. ${ }^{227}$ The implication is that such principles, despite not having direct effect by written statute, are of higher standing than the written law, for they guide the making of written law. Demosthenes gives two examples in his speech. First, the fact of robbing people of rewards $(20.46 ; 123)$ relates to the principle that there should be no punishment without

\footnotetext{
${ }^{226}$ See Markle (2004): 118.

${ }^{227}$ See Lanni (2004): 159-160.
} 
a crime. Secondly, the law forbidding a man to be tried twice for the same offence (20.147) relates to the principle of double jeopardy. Both these principles uphold respect for the force of law, and insist on a consistent and predictable application. Ultimately, therefore, they have value as rules of law, and uphold the rule of law within the democratic constitution.

Despite Demosthenes' persistent shows of respect for the democratic process, particularly the jury court, he proves to be an efficient manipulator of the jury. A good example of this process is how he deals with the idea of rewards. Demosthenes argues that Leptines' law aims to remove all public rewards (20.105). However, his position on the law is, at best, an exaggeration. As seen above, the case relates to the reward of ateleia, which is a relief from performing liturgies for the city. Demosthenes' intention seems to be to undermine the honour of the law entirely in a bid to have it denounced. While Demosthenes praises the jury with flattery, he manipulates the facts to create a perspective on Leptines' law that is incorrect so that he can have the case decided in his favour.

Later, Demosthenes uses an analogy and states ...just as a man who assigns heavy penalties for offences would be unlikely to have contemplated an offence himself, so one who abolishes the rewards for benefactions will not himself be likely to have contemplated a good deed (20.143).

Such an argument is likely to resonate with the jury due to its simplistic empirical logic. However, there is no basis for arguing that Leptines is trying to avoid doing benefactions for the city. His law aims at ensuring that Athens 
gets the liturgies it needs, which shows his concern for the city. Further, Leptines' law only removes rewards in the form of ateleia. The city still has within its power the ability to bestow other rewards to its benefactors. Demosthenes pre-empts this response, claiming that in taking away ateleia the dêmos takes away all rewards because

...how can the grant of a statue or of free maintenance be more indefeasible than that of an immunity, which you will seem to have first given and then taken away? [20.120]

However, Leptines' law is clear as to which rewards it takes away, and for what purpose. In this respect, the law upholds the power of the dêmos due to its specificity. Demosthenes proves himself a willing manipulator of the facts to ensure a legal victory.

Demosthenes hints at a moral conception that is important in how he approaches the jury with his argument. In making arguments based on morality, rather than simply legal arguments, Demosthenes achieves a broader purpose than a purely legal one. The moral conception that he draws on is a traditional Athenian one that looks back to the past era in which the good citizen farmed and fought, whereas the bad one was lazy and tended toward capital trade. Such an ideal has resonance with Aristophanes' Wealth, in which the blind god Plutus regains his sight and restores the moral order to one that upholds the honourable farmer as the ideal, while moneymaking is unnecessary. Plutus makes all citizens chrêstoi, except for the sykophant who remains ponêros. Demosthenes trades in a similar tradition. His morality seeks to uphold honour over money and in doing so expects a dêmokratia that looks 
up to those considered aristoi. Demosthenes and Aristophanes both argue that to reward citizens for being chrêstoi means that they will aspire toward being chrêstoi. Traditional modes of operation such as charis are highlighted, and the patrios politeia is affirmed through the references to Solon and Draco. Morality, for Demosthenes, is defined by tradition, and the law should therefore follow suit. Consequently, Demosthenes proves himself a strong advocate for the Athenian elite and their Periclean style of dêmokratia.

By ensuring that the overall direction of the law takes into account proper procedure and strongly held principles, Demosthenes, through the graphê mê epitêdeion theinai, attempts to establish his conception of the rule of law. Through consistency in the making and application of law, the dêmos can achieve a clear ideal of what the law is, and how it will be applied. The private enmity bound up in such disputes then acts to guide jurors as to how to apply the law, creates a moral guiding ideology, and shows the litigants to have genuine reason to appear in court. Appeals to juries often manipulate the speaker's view of what the law means, in order to gather sympathy and support. Consequently, Athenian law obtains legitimacy and can successfully act as a restraint on the power of the dêmos. Although Against Leptines contains little in the way of personal enmity, his speech takes aim at the social class behind the law.

Demosthenes depicts Leptines' law as harmful to the dêmos, and a limit on its powers. The oligarchic/democratic distinction, the utilitarian analysis, 
the examples of recipients of honours, the introduction of legal principle, and the critique of the chaotic state of the law are attempts to show that Demosthenes is a democrat whose main concern is for the dêmos. However, with strong questions as to whether these arguments actually favour the dêmos, Demosthenes' position slides. The ideals to which Demosthenes refers are consistently those that come from the elite tradition in Athens. In favour of the traditional ways, he makes implications as to the strength of custom over law, of the old over the new, and of honour over money. Nevertheless, his aims at least appear democratic, in that they seek to keep the decision making power within the sphere of the ekklêsia and the dikastêria. Demosthenes proves himself an inheritor of the Periclean tradition with its links to aristocracy and reliance on ancient ideals such as charis. Leptines' law limits the ability of the city to honour benevolence, and by corollary reduces the ability to reward individuals' honour. Elites then lose interest in competing with one another in lavish displays of public benefaction. Under the guise of upholding the law making process, and asserting the force of law, Demosthenes seeks to push a traditional, unwritten, legislative agenda. Consequently, the case stands as an example of an elite citizen using the democratic process to direct the dêmos, and the rule of law becomes a tool for the creation of a set of moral, legal, and social norms. 


\section{Chapter 5:}

\section{Hybris and the Rule of Law - Demosthenes 21, Against Meidias}

Although the basis for a legal action, hybris has its foundation more in the social psyche of Greece in general, and democratic Athens in particular, than in its legal institutions. The concept of hybris appears in Greek literature throughout history, from Homer to Plato and beyond. While the graphê hybreôs was a legal action, the written form of the law of hybris assumed knowledge of what hybris was. The social and historical uses of hybris are, therefore, important in understanding its continued use in the Athenian law courts of the fourth century. However, no graphê hybreôs speeches survive, leaving scholars in the position of having to glean a legal understanding of hybris from other forms of action. ${ }^{228}$ For example, the case of Demosthenes against Meidias, a probole, refers constantly to the concept of hybris, without being a graphê hybreôs. Demosthenes describes Meidias as a hybristês, and shows how his purposes conflict with those of the dêmos. In the process, Demosthenes constructs an interpretation not only of what a hybristes is, but also of Athenian law itself. By showing the hybristês as opposing dêmokratia, Demosthenes highlights the importance of the rule of law in upholding demotic power against the power of the wealthy hybristês. In essence, Demosthenes conceives the conflict as a power struggle that the dêmos will lose unless it uses its combined force to overcome the natural advantages of wealth. The case of Against Meidias ultimately stands as an example of how

\footnotetext{
${ }^{228}$ Ober (1996): 92.
} 
litigants used important social concepts in the Athenian law courts to manipulate the opinion of the jury towards their position in a struggle based in personal enmity.

Hybris is heavily embedded in ancient Hellenic tradition, and there are many references in the ancient Greek corpus. ${ }^{229}$ Aristotle defines hybris as:-

Doing and saying things at which the victim incurs shame, not in order that one may achieve anything other than what is done but simply to get pleasure from it...The cause of the pleasure for those committing hybris is that by harming people they think themselves to be superior...Dishonour is characteristic of hybris, and he who dishonours someone slights him, since what has no worth has no honour, either for good or for bad. (Aristotle, Rhetoric, 1378d23-35).

In forming such a definition, Aristotle isolates the fundamental nature of hybris, and allows for a social, political, and legal understanding of the concept. ${ }^{230}$ Its appearance in his manual for orators suggests that Aristotle provides a definition that can elucidate the use of hybris in the law courts at Athens in the fourth century. ${ }^{231}$ Importantly, Aristotle places a strong emphasis on the disposition of the agent. ${ }^{232}$ In a similar vain, Theophrastus describes hybris as "...a certain scorn for all the world beside oneself” (24.1).

The connection between hybris and the anti-democratic temperament is a commonplace of forensic oratory. Amongst the available speeches from

\footnotetext{
${ }^{229}$ For example, Hesiod, $W \& D .133-7,146,191-2,214-18,238-41$; Homer, Il. 1.185-7, 1.2023, 1.214, 13.620-39; Od. 1.227, 1.368, 4.321, 16.409-10; Pindar, Pyth. 11.54-8; Olympian, 13.6-11; Solon, fr. 9.3; Plato, Phaed. 237e; Soph. 228d-9a; Politicus, 308e-309a; Sophocles, Ajax, 1087-90; Per. 805-8; Ag. 271-3, 532, 762-7, 1612; Thuc. 6.28.2, 3.39.4; Hdt. 7.8, 16, 18; Xen. Cyr. 7.62-3.

${ }^{230}$ Fisher (1992): 7.

${ }^{231}$ Fisher (1992): 9.

${ }^{232}$ Cairns (1996): 2; 28-9.
} 
Athenian dikastêria are some 292 references to hybris. For example, Isocrates refers to hybris as "a matter of public concern" (Isoc. 20.2). He takes the case against Lochites not because of an assault, but because of the outrage and indignity inflicted (Isoc. 20.5). Unlike other types of injustice, hybris degrades all of the polis (Isoc. 20.9). Hybris is a public crime against the whole community (Isoc. 20.20); hence, the action is a graphê. Aeschines shows that hybris is illegal, whether committed against man, woman, or boy, free or slave (Aesch. 1.15). The purpose of including slaves was to ensure that no citizen commits hybris, a crime that leaves citizens unfit to share in the dêmokratia (Aesch. 1.17). Hybris is a breach of the dignity accorded citizens in a democratic society irrespective of the legal status of the victim. The fall of dêmokratia was due to the desire of individual oligarchs to commit hybris (Isoc. 20.10). The hybristês despises the established laws (20.22). In his suit against Conon, Demosthenes describes Conon as hybristês for his excessive behaviour after assaulting Ariston (Dem. 54.2). After beating Ariston and taking his cloak, Conon and his sons said "many shocking things" (Dem. 54.8), and then performed like a victorious fighting cock (Dem. 54.9). The common theme in the three orators is that a hybristês is arrogant, acts excessively, and places the dêmokratia in danger due to his disregard for the laws or any higher power. ${ }^{233}$ Hybris, the most direct affront to the democratic rule of law, is clearest where an individual usurps the dêmos' legitimate control of force within the polis.

${ }^{233}$ Cairns (1996): 8, 14, 31. 
The action of hybris in the Athenian law courts required the existence of a law, breaches of which were prosecuted as a graphê hybreôs. As a graphê, an action of hybris could be taken by anyone who wished (ho boulomenos) ${ }^{234}$ The law does not offer a definition of hybris, but simply states that "If anyone commits hybris...", and includes behaviour that is paranomôn (Dem. 21.47). Such broad wording implies that hybris represents a commonly held concept, and allows for a wide range of behaviour to potentially be considered as hybris.

Hybris requires two elements for a legal action to occur, being what criminal lawyers refer to as mens rea, a guilty mind, and actus reus, a guilty act. ${ }^{235}$ While a person may come under suspicion for possessing a guilty mind, that is to say, they are hybristês, there will need to be a manifestation of the hybris for there to be a legal charge. Cairns argues that some individuals are more sensitive to perceived hybris than others, and suggests that the test is whether the accused hybristês has attempted to achieve a quantitative excess of time to the detriment of the victim. ${ }^{236}$ While it is sufficient for a person to be internally hybristês, a successful legal charge will depend on an act or omission that can, at the very least, point to the existence of a hybristic mind. ${ }^{237}$ Hence, in the case Against Conon, the beating and stealing of Ariston's cloak are serious acts, but the crowing like a chicken and dancing is a clear signal of hybristic intent (Dem. 54.9). While an act of violence would

\footnotetext{
${ }^{234}$ Fisher (1992): 36.

${ }^{235}$ Simester \& Brookbanks (2002): 43.

${ }^{236}$ Cairns (1996): 16.

${ }^{237}$ For an omission as hybris, see the discussion of Melanthius in Homer's Odyssey, at Cairns (1996): 10 .
} 
normally incur an action of dikê, hybris makes it a public crime, or graphê. Nevertheless, in Ariston's case, he uses the existence of hybris in Conon to highlight himself as a moderate citizen. ${ }^{238}$ Consequently, he takes only an action for assault, a dikê aikeias.

Significantly, none of the surviving body of law court speeches comes from a graphê hybreôs, which creates the position whereby an understanding of the legal conception of hybris must come from reading other forms of action that discuss hybris. ${ }^{239}$ The date of inception of the graphê hybreôs is unclear. Typically, litigants from the fourth century claim it has Solonian roots. ${ }^{240}$ That Athens prescribed a legal action for hybris as a crime shows the importance of honour, or timê, in the Athenian socio-political framework. ${ }^{241}$ Honour is central to the traditional elite mindset, and one of the bases for the assessment of a person as aristos. Hybris is useful for testing an individual's timê, and becomes a tool of power play within the polis. ${ }^{242}$ Nevertheless, the class aspect should not be too heavily emphasised at the expense of other potentially

\footnotetext{
${ }^{238}$ De Brauw (2002): 163-5.

${ }^{239}$ For uses of forms of hybris in forensic oratory, see Aesch. 1.15, 16, 17, 108, 137, 141, 185; 2.8, 111, 181; 3.237, 238, 245; And. 4.14, 15, 21; 4.4; Dem. 1.23, 27; 7.44; 8.62; 9.34, 60; $10.64 ; 17.4,23,26 ; 18.48,132,183 ; 19.46,85,220,246,287,310 ; 21.1,4,6,7,8,9,11,15$, $18,21,25,31,32,34,36,37,38,39,41,44,45,46,47,48,49,55,57,58,67,68,71,72,73$, $74,75,76,81,82,97,98,100,105,106,108,123,126,131,138,143,146,147,148,159$, $160,170,179,183,185,187,189,204,207,209,211,216,217,219,222 ; 22.1,21,54,58,63$, $68 ; 23.56,57,59,81,120,122,141 ; 24.15,77,125,138,143,166,171 ; 25.19,50 ; 27.68$; $30.2,36 ; 33.30,42,47 ; 30.2,36 ; 34.30,42,47 ; 43.71,75,77,84 ; 45.1,6,83,86 ; 47.41 ; 48.55$; $53.1 ; 54.1,8,10,15,16,17,20,21,24,25,28,32,33,40,41,43,44 ; 56.12 ; 57.6 ; 59.12,51$, 86, 96, 107; 60.8, 29; Din. 1.23; Hyp. 2.6; 5.9; 6.12; Isaeus, 2.15, 33; 3.46, 48; 4.11; 5.24; $6.48 ; 8.1,45 ; 12.12$; Isoc. $2.16 ; 4.39,80,111,151,153,182 ; 6.36,42,54,108 ; 8.99,108$; $9.10,19 ; 12.47,61,83,160 ; 14.16 ; 15.251 ; 16.23,48 ; 20.4,57,10,15 ;$ Lys. $1.4,16,25 ; 2.9$, $14 ; 3.5,7,17,23,26,34,40 ; 8.5 ; 10.26 ; 11.9 ; 12.98 ; 14.26,29 ; 20.3 ; 22.5 ; 23.5 ; 25.15,16,18$, $25 ; 32.10 ; 33.2$.

${ }^{240}$ See for example Aesch. 1.15-7.

${ }^{241}$ Fisher (1992): 494; Cairns (1996); Wilson (1991): 166-7.

${ }^{242}$ Fisher (1992): 497.
} 
motivating factors. The graphê hybreôs, therefore, is a way for Athens to assert the importance of the rule of law in order to uphold the power of the dêmos, and avoid the possibility of tyranny. However, it also becomes a tool for pursuing political or social rivals through the law courts in order to eliminate them.

The case of Demosthenes 21, Against Meidias, involves a long-standing personal dispute between two Athenian citizens. Meidias' brother challenged Demosthenes to accept a trierarchy. Meidias, possibly helping his brother, burst into Demosthenes' house and abused Demosthenes' mother and sister. ${ }^{243}$ The two had not previously known each other, but the event ensured that a bitter personal enmity erupted involving various law suits and disagreements. ${ }^{244}$ In 347/6 BC, Demosthenes issued an action against Meidias for an assault during a religious festival. ${ }^{245}$ The case relates to this incident.

Demosthenes continually accuses Meidias of asebeia and hybris, but chooses the probole over the graphê asebeias or the graphê hybreôs. ${ }^{246}$ The probole procedure is a special case in Athenian law. Against Meidias is virtually the only source of the action of probole $\hat{e}^{247}$ Probole deals with offences that occur during the contests or procession of the festival of Dionysia (21.8-9). ${ }^{248}$ Unusually, it takes place at the ekklêsia, rather than the dikastêria, making the probole a much more public action than the graphê,

\footnotetext{
${ }^{243}$ MacDowell (1990): 3.

${ }^{244}$ See Dem. 21.78-101 for Demosthenes' version of the route of their legal history.

${ }^{245}$ MacDowell (1990): 10-11.

${ }^{246}$ MacDowell (1990): 17; cf: Harris (1989) who argues that the case was a graphê hybreôs, and came before a jury court. Ober (1996) argues from the assumption that it was in fact delivered to the jury court.

${ }^{247}$ MacDowell (1990): 13; See also Ath. Pol. 59.1-2.

${ }^{248}$ MacDowell (1990): 7-8.
} 
which occurs in the law court. As the assault took place during the festival, it is seen as potentially affecting the wider community, which supports taking a public rather than a private action. However, the private enmity between the two litigants was severe, and Demosthenes had much to gain from making the incident known to as many people as he possibly could. Meidias' push for private rather than public action supports the view that personal enmity was the underlying motivation for such cases. ${ }^{249}$ Consequently, while Demosthenes shows a valid reason for choosing a public case, it also helps him in his pursuit of personal vengeance.

In 348BC, Demosthenes volunteered as chorêgos of the men's dithyramb in the Dionysia (21.13-14). Meidias objected to Demosthenes' choristers receiving exemption from military duties (21.15), destroyed Demosthenes' sacred clothing and golden crowns (21.16), interfered with various festival officials (21.17), and, most offensively, "He treated my person with insolence (hybrisen), and he was the man most to blame that the tribe which was best in the contest did not win" (21.18). Demosthenes frames the attacks as being on himself and his fellow tribesmen (21.19) and shows that Meidias has behaved inappropriately against many within the community, showing the need for public punishment (21.20). Meidias has interfered with the dêmos' ability to adjudicate competition within the polis. Demosthenes then proceeds to pre-empt Meidias' arguments against himself.

First, Meidias will argue that Demosthenes should have brought a private action based on wilful damage or assault, rather than a public action

\footnotetext{
${ }^{249}$ Fisher (1992): 44.
} 
(21.25). Demosthenes argues that, had he brought a private action, Meidias would be arguing the opposite, that he should have brought a public action. However, the probole specifically relates to offences at festivals, Meidias acted at a festival against a festival official, and a probole is appropriate (21.26). Consequently, the procedure is justified.

Second, Meidias will ask the jury not to hand him over to Demosthenes, saying, "Don’t destroy me because of Demosthenes!" (21.29), implying that Demosthenes is himself using power unjustly against fellow citizens. His counter is that the jury does not hand the defendant over to the prosecutor and that when they punish an offender, the jury will be “...confirming the laws in your own interest" (21.30). However, Demosthenes here constructs a straw man. Meidias is unlikely to make such an argument if it is known that the prosecutor does not take responsibility for the punishment. Nevertheless, the argument allows Demosthenes to draw the jury in by showing the correlation between punishing Meidias and their own interests. Consequently, the argument acts as a foil to introduce the topos of collective self-interest.

Third, Meidias will argue that Demosthenes is the victim, rather than the dêmos (21.31). However, Demosthenes argues that not only was he assaulted, but another chorêgos was also bullied. He then uses an analogy to draw out a private/public distinction that supports his public action (21.32). If a man treats insolently a thesmothetês, then a graphê hybreôs is appropriate. 
However, if the thesmothetês is acting in his official capacity as a thesmothetês, then the man will be permanently disenfranchised because the man who does that is using insolence (hybris) also against the laws, and against the crown that belongs to you all, and against the city's name, for the name thesmothetês does not belong to any person, but to the city (21.32).

Demosthenes was acting in an official capacity as chorêgos when the assault occurred. Therefore, the act was an act of hybris against the whole city, which reflects the Solonian conception of hybris as a public crime (graphê). Further, Demosthenes was wearing the crown in an act of ritual devotion to Dionysus. Therefore, the act was an act of impiety (asebeia) against the gods. Consequently, a public action is appropriate.

Demosthenes also highlights the religious nature of Meidias' offending. Demosthenes claims that, had he not been a chorêgos at the time of the offence, Meidias would be guilty simply of hybris (21.51). The choruses are held in favour of the god Dionysus, and in accordance with oracles. They are strongly grounded in religious tradition, highlighting the close connection between religion and law. Consequently, where Demosthenes was acting in his capacity as a chorêgos when the assault took place, Meidias should be condemned not only for hybris, but also for asebeia. The 1000-drachma fine for striking a man wearing a crown and serving the god, which shows clearly the desire to avoid the occurrence of such offences, strengthens such a position.

Demosthenes returns to the private/public distinction in a bid to highlight the problem of power and justice. Demosthenes argues that "the 
lawmaker" conceived all violent acts as offences against everyone, and harmful to all because

strength is possessed by a few men but the laws belong to all, and the man who is persuaded requires a private remedy, but the man who is compelled, a public one (21.45).

The argument acknowledges the ability of powerful individuals to do wrong, and the position of law as the legitimate tool for restraining or limiting such power through the force of the combined community. ${ }^{250}$ Demosthenes includes hybris as fitting into the public category, as the insolent man wrongs the city, and even slaves have protection from hybris. Demosthenes claims that this is because the lawmaker sought to focus not on the identity of the victim, but on the nature of the act (21.46). Demosthenes' position emphasises the law as the educative vehicle for curing an individual's character of hybris, and enforces the idea that it is up to the jury to perform the educative duty through the power of the law.

The question of intent highlights the issue of Meidias' motivation. Demosthenes argues that if an opposing chorêgos performs acts such as Meidias has out of eagerness for victory, then such acts could be excused (21.66). However, Meidias, a private individual who spent no money on a chorus (21.61), acted out of private enmity to show himself more powerful than the laws (21.66). Demosthenes' unavoidable conclusion is that Meidias "...had no other motive besides hybris" (21.181). Alternatively, the motivation

\footnotetext{
${ }^{250}$ Ober (1989): 293 notes that the self-help nature of legal retribution still favoured the rich
} and powerful over the poor and weak. 
of Athenians to participate in such institutions as liturgies emerges where Demosthenes claims that

the thing that makes them all emulous and willing to spend money, I think, is that each of them believes he enjoys equality ( $t a$ isa) and fairness (ta dikaia) in a dêmokratia (21.67).

Fairness and equality are two core principles of demokratia. Meidias' hybris is clear in that he considers himself greater than others, and therefore not subject to either fairness or equality. Meidias threatens Athenian isonomia. Had he considered himself equal, argues Demosthenes, he would have taken on the role as chorêgos and competed for honour. Consequently, Meidias proves himself unfit for life in a dêmokratia.

Moreover, Meidias will try to show that many people suffer the type of harm Demosthenes describes, and the jury should not see it as sufficiently unusual to punish Meidias (21.36). Demosthenes argues that such incidents occur because offenders avoid punishment, and that punishing Meidias will have a deterrent effect on others within the polis (21.37). If the jury does not inflict the proper punishment, then there is no point in having any laws (21.57). The moral position Demosthenes leaves the jury in is that it is either desirable to prevent such incidents, in which case they must punish Meidias, or it is undesirable to punish Meidias, in which case they must accept that such incidents will continue. Consequently, it is up to the jury to issue retribution "on behalf of the laws and the god and yourselves" (21.40), and in doing so uphold the rule of law. 
Finally, Meidias will argue that his behaviour was out of anger and should therefore be forgiven (21.41). However, Demosthenes claims that Meidias shows a consistent pattern of such behaviour, proving his argument from anger to be fallacious. The position, therefore, is that Meidias is in fact guilty of deliberate insolence rather than of acting out of passion. The argument becomes relevant again toward the closing of the speech, where Demosthenes argues that Meidias' plea of humility in court will prove he is capable of humility, and therefore his act of hybris was intentional (21.186). If such an act is deliberate, then the hybris is far worse than if it were simply accidental. Where Demosthenes shows Meidias' main potential arguments as invalid or insufficient to secure a defence, Demosthenes claims that the jury must find him guilty and decide on the appropriate punishment. To emphasise Meidias' lack of character, Demosthenes uses his own as a comparative.

Demosthenes displays his character as sôphrôn. ${ }^{251} \mathrm{He}$ asks the jury When I exercised so much care to prevent any disastrous result that I didn't defend myself at all, from whom ought I obtain atonement for what has been done to me? From you and the laws, I think; and an example ought to be set, to show everyone else that all insolent bullies (hubrizontas) should not be fought off at the moment of anger, but referred to you in the knowledge that you are the guarantors and guardians (phulattonton) of legal protection for victims (21.76).

Contained in this argument is the recurring theme of the power of the law and the position of the jury as its guardian (nomophulax). Demosthenes conceives an ideal of law as one in which people place many of their rights of retribution, which creates a restraint on individual anger (orgê). In return, the law protects

${ }^{251}$ Ober (1996): 103. 
their interests and ensures that all people uphold the law. All citizens have the ability to affect the law, and no person within the community should hold more power than the law itself. Fundamental to this conception is trust, in that citizens must be able to trust that the law can reciprocate for them to give up certain rights freely. Demosthenes states that citizens give up orgê, which otherwise leads to stasis, in the trust that the law can ensure retribution for any offence. $^{252}$ The jury then takes the role of expressing the just anger of the community, which helps maintain social order. Consequently, it is insufficient to ignore the continued place of coercion in the Athenian politeia, as Ober does. Unarticulated here is the idea of a social contract, which is an implication of the reciprocity of rights and protection. Under Demosthenes' argument, Meidias places the social contract in danger by undermining the inherent trust within the system to the extent that "it isn't safe, it appears, to prosecute Meidias when he wrongs you..." (21.87). Where such is the case, the law cannot, and does not, rule, but rather the strong and wealthy within the polis.

Demosthenes makes the claim that Athens is a city in which the rule of law prevails (21.150). Athenian citizens' equality is based on the law, and all things good in Athens are due to the laws, not wealthy individuals (21.188). If the jury is to allow Meidias to go free of punishment, then it is the same as punishing Demosthenes with hybris for performing the liturgy of chorêgos (21.189). In a final effort to convince the jury of Meidias' hybris,

${ }^{252}$ This is consistent with Ober's "coercion paradigm" of power, which he rejects as functioning in Athens. See Ober (1996): 88-89; above, p17. 
Demosthenes claims that Meidias thinks the jury will not know how to deal with him, and describes Meidias as "rich, bold, with a big head and a big voice, violent, shameless..." and asks where he will find punishment if not at the hands of the jury (21.201). He then leaves them with a warning to

Let no one in a dêmokratia be so mighty that his advocacy causes the one man to continue bearing the burden of hybris and the other to go unpunished" (21.207)

Demosthenes shows Meidias to be a particularly egregious example of the hybristês, and plays upon the jurors' fears of the rich as a separate class (21.212-13) highlighting “...the profundity of Athenian fears regarding the potential power of wealth to undermine the fundamental principles of the democracy." 253 As Fisher states, it is Meidias' wealth that allows him to treat others with hybris and in that sense is more or less the cause of his hybris $(21.98 ;$ cf. $100 ; 123 ; 138 ; 185) .{ }^{254}$ The rule of law requires that the jury take control of the polis, and maintain power within it. Without full protection for all people, everyone will fear for their safety (21.220). The legal system will then be ineffective, and anarchy will reign. Effective punishment of a criminal, therefore, creates an educative and deterrent effect for others, and shows the force of the dêmos. Where such is the case, the constitution (politeia) is worthy of the trust that people place in it, and people will offer the appropriate honour to it and the people within it.

As an extension of the power/justice problem, Demosthenes attempts to highlight the position of the poor in seeking redress from the rich.

\footnotetext{
253 Ober (1989): 209.

${ }^{254}$ Fisher (1992): 48.
} 
Demosthenes claims that the rest of the population, he says "we", lack equality and legal protection in facing the wealthy in a legal dispute (21.112). Whereas the poor face immediate prosecution and cannot normally find witnesses even to tell the truth, the wealthy can delay court actions until cases have gone cold, and can afford to ensure they have ample witnesses and supporters. Demosthenes attempts to use the argument as actual evidence that the rich hybristês, such as Meidias, holds power over the dêmos. However, Demosthenes conveniently avoids the fact that he also is wealthy, and instead tries to ally himself with the poor members of the dêmos.

As a vehicle for mutual reciprocity, Demosthenes encourages the court to repay Meidias. He states that

No one deserves pity if he pities no one, and no one unmerciful deserves mercy (21.100).

Demosthenes bases his argument on the principle of reciprocity, the 'golden rule' of doing unto others as you would have them do unto you. Whereas those who behave well toward everyone deserve good treatment in return, so too those who behave violently and insolently to everyone deserve to be treated in return (21.101). Meidias is of the latter type of citizen, and should be treated without pity or mercy. Justice, in Meidias' case, should not be tempered with mercy. In effect, his charis should be severe punishment.

Demosthenes also uses the rich versus poor divide to highlight the issue of due process. He warns of rich and powerful citizens' ability to coerce people into avoiding lawsuits and says 
one should render an account and stand trial for charges which anyone makes, and only retaliate against those who proceed against one unjustly (21.125).

The people most likely to suffer such treatment are the poorest and weakest, whereas the likeliest to be insolent and avoid legal action are the richest (21.123). In doing so, the rich hybristês make poorer citizens fearful of attempting to find recourse to the law, and ultimately place in jeopardy the fundamental freedom and equality of speech (isêgoria), liberty (eleutheria), and political equality (isonomia) inherent in dêmokratia (21.124). ${ }^{255}$ In essence, Demosthenes creates an image in which the rich hybristês pursues his own self-interest as against the interest of the greater community, a situation in which "the strong do what they can and the weak suffer what they must" (Thuc. 5.89). Such a position is contrary to the idea of demokratia and the rule of law.

Demosthenes tries to rally the Athenians as a group against Meidias. First, Demosthenes claims that as the hybris is an offence against a chorêgos, it is also an offence against the tribe the choregos represents, which is one tenth of the Athenian population (21.126). Insults against Demosthenes and the laws are insults against every Athenian and the god. In taking the case, Demosthenes is not only speaking for himself, but also for the entire dêmos. Depicting himself as the paradigmatic prostatês tou dêmou who acts as the watchdog for the dêmos, Demosthenes implies that the blow against him is a blow against the laws, the gods, and the polis. Further, Demosthenes shows that, as individuals, Athenians are weaker than the rich hybristês, either in

\footnotetext{
${ }^{255}$ Ober (1989): 217.
} 
friends or in resources (21.140). A united dêmos can put a stop to hybris. However, the dêmos must take its chances to mete out a suitable punishment to a common enemy, thereby ensuring the place of justice $(21.142) .{ }^{256}$ Such a position requires that the dêmos refuse to tolerate anything when hybris is combined with it (21.143). Consequently, Demosthenes requires the jury to focus on their common interest and support him against the corrupt and wealthy hybristês Meidias, using Athenian law to protect Athenian freedom.

Demosthenes makes personal attacks on Meidias, contrasting the images of Demosthenes as a hoplite versus Meidias as a commander given to extravagance who never even put on a breastplate (21.133). Later, Demosthenes compares him to Alcibiades, pointing out that Alcibiades also struck a chorêgos (21.147). However, Alcibiades was himself a chorêgos, and the current law on hybris had not been passed. Alcibiades mutilated the Hermai, an act of impiety, whereas Demosthenes claims that Meidias is guilty of total destruction of sacred things. Further, while Alcibiades had a distinguished family ancestry, Meidias is of low birth, has no ability as a soldier let alone a general, abuses many people in his speeches, has a stupid mother, is hustling and violent, and uses his own things as though they were others' (21.148-50). The comparison sets the tone for Demosthenes to suggest to the jury that

...you should honour and admire...a man whose distinction and aspiration to honour are in things of which the majority of you all have a share. You'll find that none of this applies to Meidias (21.159).

\footnotetext{
${ }^{256}$ Ober (1989): 218.
} 
Meidias is the opposite of aristos, and ignores all of the ties integral to dêmokratia. He is the paradigmatic poneros $(21.138,148,189)$. Alcibiades was an historical figure linked not only with the time of Athenian greatness and prosperity, but also by his connection with oligarchy and tyranny. ${ }^{257}$ Demosthenes focuses on the parts of Meidias' behaviour that exceeded Alcibiades in criminality, and in doing so avoids connecting him with Alcibiades' virtue. Meidias' character is ultimately conducive to neither oligarchy nor dêmokratia, but more closely aligned with tyranny.

In fact, Demosthenes makes one more comparison, between Meidias and the tyrant slayers, where he claims that even Harmodius and Aristogeiton would not have been allowed to act with hybris, but it was precisely because they prevented hybris that they received eternal rewards (21.170). Therefore, to allow Meidias to continue to live in the dêmokratia is to allow tyranny to exist. The implication is that to banish Meidias is to uphold the legacy of Harmodius and Aristogeiton, expelling unjust power and upholding the honour of the dêmos. In doing so, Demosthenes shows the democratisation of timê, formerly an aristocratic value. ${ }^{258}$

In a similar fashion, Demosthenes makes a comparison between Meidias and Strato. Strato is exemplar of the working Athenian, whereas Meidias is exemplar of the rich hybristês. When a rich hybristês attacks a poor citizen, the poor loses his citizenship, which is "the one attribute...that should

\footnotetext{
${ }^{257}$ Wilson (1991): 182.

${ }^{258}$ Ober, (1996): 104-5.
} 
have protected him from the violence of the uncontrolled elite individual., ${ }^{, 259}$ The jury must then strip Meidias of the source of this hybris, his wealth. ${ }^{260}$ For any misdeeds he might commit he would then pay the penalty, just like "the rest of us" $(21.138){ }^{261}$

Finally, Demosthenes analyses the idea of the rule of law, and points to the basis of demotic sovereignty. Demosthenes asks the jury to "...consider and investigate the question of what it is that gives the power and control over everything in the state to those of you who are jurors at any time..." and answers "...your power is derived from the laws" (21.223). "And what is the power of the laws?" (21.224) Demosthenes acknowledges that the laws are written documents, and have no actual power to do anything to save anyone from danger. "What is their strength then? You are, if you guarantee them and make them effective on each occasion for anyone who asks. So the laws get their power from you, and you from the laws" (21.224) and he commands the jury that "you must therefore stand up for them..." (21.225). This passage represents the traditional democratic Athenian perspective of legal theory, and harks back to the patrios politeia. While he highlights the importance of the rule of law, he also acknowledges that law is a fiction. Law, in the Athenian conception never achieved an externalised, abstract state that could be separated form the idea of Athenian demotic interest. ${ }^{262}$ However, it is the manifestation of demotic power and the ultimate outcome of democratic

\footnotetext{
${ }^{259}$ Ober (1989): 211; Ober (1996): 100-1 refers to the "basket" of privileges that make up "citizen dignity".

${ }^{260}$ Ober (1989): 211.

${ }^{261}$ Ober (1989): 211.

${ }^{262}$ Ober (1989): 300 .
} 
decision-making. The rule of law is, in fact, the rule of the dêmos. Where the dêmos rules, the polis is in a state of demokratia. Consequently, dêmokratia requires the rule of law, which itself requires the demos to uphold the laws and exert its legitimate force against those who threaten the safety of the community through illegal action. The implication of Demosthenes' conception is that there exists at Athens a dual sovereignty between the dêmos and its laws. Only under such a system can the polis be in a state of true and stable dêmokratia. The rule of law, therefore, is essential for the existence of a stable dêmokratia.

Demosthenes clearly articulates a theory of Athenian law that finds its legitimacy in reciprocity between the "people" and the "state". Inherent in the reciprocal arrangement is trust that each will perform its proper and appropriate role within the polis. Meidias, the rich hybristês, proves to be unwilling to uphold his part of the agreement and instead chooses to use his wealth and power toward his own ends. His behaviour conflicts with the interest of the dêmos, and undermines the power of Athenian laws. Demosthenes shows that Meidias does not belong in a democratic polis that relies on the rule of law. Consequently, in taking action against Meidias, Demosthenes upholds the power of the laws, the force of the dêmos, and positions the jury as the guardian of the polis. However, integral to the case is the personal enmity between the two as citizens, which Demosthenes makes clear. While the existence of such enmity helps Demosthenes avoid claims of 
sycophancy, it also shows his true motivation for taking the action. In a bid to defeat a personal enemy, Demosthenes takes a legal action in which he manipulates the very idea of law, upholding the jury as guardians against the wielder of unjust power within the polis. Ultimately, Demosthenes manipulates the concepts of hybris and the rule of law to convince the jury that Meidias is undemocratic, and therefore not fit to stay in the community. 


\section{Chapter 6}

\section{Euthynai: Rule of Law and the Sovereignty of the Dikastêria}

The ability of citizens to scrutinise officials was a long-standing power, and central to the strength of demokratia. Aristotle attributes the introduction of the euthyna at Athens to Solon. ${ }^{263}$ Solon allowed the poor to have input into the working of the polis, while upholding the traditional position of wealthy elites as the leaders of the community. ${ }^{264}$ Initially, the Areopagus controlled euthynai. However, after the reforms of Ephialtes euthynai came under the jurisdiction of the dikastêria. By inspecting the activity of officials during their tenure, the dêmos held a strong power over political leaders. For Athenians, accountability of officials was the key to good government, or eunomia. ${ }^{265}$ The euthyna gave the poor an important power over the wealthy elites of the community as they could hold elites accountable for their political activity and adjudicate on disputes between elites, which upheld the dêmos' position as the adjudicator of timê. Euthyna therefore was crucial to the rule of law in the Athenian dêmokratia, particularly of the fourth century, through the power it gave the dêmos. For example, after the restoration of dêmokratia in 403/2 BC, the Thirty, and certain other oligarchic officials, were excluded from the amnesty unless they passed their euthyna. ${ }^{266}$ However, it was also another mechanism by which elites could attack each other in their endless rounds of

\footnotetext{
${ }^{263}$ Aristotle, Politics, $1274 \mathrm{a} ; 1281 \mathrm{~b}$.

${ }^{264}$ Solon, Fr.5; Dornum (1997): 1490.

${ }^{265}$ Roberts (1982): 6.

${ }^{266}$ Ath. Pol. 39.6; Todd (1993): 113.
} 
enmity such as is evident in the court case between Demosthenes and Aeschines.

The euthyna is the companion of the dokimasia. Dokimasia and euthyna were ways of ensuring the proper public behaviour of politicians. ${ }^{267}$ The dokimasia was an obligatory procedure by which a jury, under the presidency of the thesmothetai, checked that those voted in or drawn by lot for a particular official position were entitled to hold it. ${ }^{268}$ Notably, loss at a dokimasia trial did not result in a punishment. ${ }^{269}$ During tenure, an official could be charged for misusing his authority or neglect of duties through actions such as apokheirotonia, or eisangelia. ${ }^{270}$ However, the most important inquiry into the conduct of officials was the euthyna. ${ }^{271}$ The euthyna occurred at the end of the official's tenure, and was compulsory for all citizens elected or allotted to perform public duties, bar jury members. The procedure of euthyna occurred within thirty days of the end of tenure, and came in two parts. ${ }^{272}$ First, there was a financial audit to ensure that the official had not embezzled money (klopê), or accepted bribes (dora). ${ }^{273}$ Second, the official faced investigation in the open agora, at which any citizen who wished (ho boulomenos) might bring forward accusations of neglect of duty or improper

\footnotetext{
${ }^{267}$ Ober (1989): 329.

${ }^{268}$ MacDowell (1978): 167; Sinclair (1988): 78; for dokimasia speeches see Lysias 16, 25, 26, 31 - note that Lysias refers in these speeches to acts carried out during the reign of the Thirty.

${ }^{269}$ MacDowell (1978): 168.

${ }^{270}$ MacDowell (1978): 169.

${ }^{271}$ MacDowell (1978): 170.

${ }^{272}$ Roberts (1982): 17; MacDowell (2000): 17.

${ }^{273}$ MacDowell (1978): 170-71.
} 
use of power. ${ }^{274}$ With the euthyna completed, an exonerated official could return to normal life as a citizen in good conscience. ${ }^{275}$ Alternatively, a guilty official faced harsh financial penalties (Ath. Pol. 54.2). An official could be prosecuted not only for corrupt behaviour, but also for honest mistakes (Hyp. 5.25-26), and any citizen was able to take a case in the dikastêria against an official who had undergone a euthyna (Ath. Pol. 48.4-5). ${ }^{276}$ Establishing democratic procedures for proper political conduct allowed the fifth-century Athenians to establish rigorous checks on the use of political power by magistrates, officials, and those who handled public money. The euthyna, therefore, became one of the most important tools of demotic power in the dêmokratia. With accountability guaranteed, officials were likely to ensure that they had clear directions from the ekklêsia, particularly through psêphismata, rather than relying too heavily on their own initiative, thereby assuring demotic sovereignty. ${ }^{277}$ Euthynai therefore ensured that where the dêmos had spoken through law, its officials acted consistently with its desires and interests.

In the previous case studies, the place of the graphê mê epitêdeion theinai and the graphê hybreôs as tools of demotic power became clear. Both actions enabled legitimate processes for asserting the place of the rule of law in the demokratia. However, they also became vehicles for intra elite struggles. Both factors help to strengthen demotic power, as the dêmos takes

\footnotetext{
${ }^{274}$ MacDowell (1978): 171.

${ }^{275}$ Roberts (1982): 6.

${ }^{276}$ Christ (1998): 135.

${ }^{277}$ Sinclair (1988): 79.
} 
control of its own legal process, and sits in judgement on the timê of its key citizens. The present case extends such a position. The euthyna outlines a legal process to ensure official accountability, and elites used the process to pursue personal and political feuds. On the False Embassy, an exemplary case, stands as one of the great law court battles of the Athenian legal system.

Athens and Macedonia had been at war since 357BC, and the two agreed to negotiate a peace settlement in $347 \mathrm{BC}$, at which an Athenian embassy, including Aeschines and Demosthenes, established the Peace of Philocrates with Philip. ${ }^{278}$ The peace failed, however, and Demosthenes attempted to separate himself from it at the first opportunity. ${ }^{279}$ After a second embassy to Philip, Demosthenes used the process of euthyna to prosecute Aeschines. ${ }^{280}$ According to Yunis, Demosthenes had two motives for taking the case: to separate himself publicly from the failed peace; and to remove his greatest political rival, Aeschines, from Athenian politics. ${ }^{281}$ In doing so, Demosthenes would then become the predominant figure in the Athenian political environment. In the event, Aeschines won by roughly 30 votes out of 500, or possibly 1,000, jury members. ${ }^{282}$ Nevertheless, Aeschines' influence severely diminished after the trial, and Demosthenes continued his rise to political dominance.

Demosthenes begins his speech by asking the jury to favour "justice and the oath that each of you swore before entering the court", and shows that

\footnotetext{
278 Yunis (2005): 114.

${ }^{279}$ Yunis (2005): 115.

${ }^{280}$ Yunis (2005): 116.

${ }^{281}$ Yunis (2005): 117.

282 [Pseudo] Plutarch, Aeschines, 840c.
} 
such ideals require the jury to take into consideration not individual partisan interests, but rather the interest of the whole city (Dem. 19.1). In doing so, Demosthenes attempts to place himself firmly as the representative of Athenian interests, the prostatês tou dêmou, and therefore Aeschines as opposing such interests. To highlight Aeschines' position, Demosthenes uses an earlier trial involving Aeschines and Timarchus, deducing that Aeschines prosecuted Timarchus in a bid to prevent him from acting against Aeschines in an earlier euthyna (Dem. 19.2). The inference is that Aeschines, opposing open legal justice, attempts to manipulate the dikastêria to promote his own interests and avoid prosecution for wrongdoing. Further, where an official undermines the democratic process of scrutiny through fear, the dêmos loses control of the polis and therefore becomes akyros (Dem. 19.2). Such behaviour exposes the power of the demos to risk, and the polis is in danger of oligarchy or tyranny. Aeschines, therefore, deserves extreme punishment (Dem. 19.3). Ultimately, Demosthenes shows that Aeschines seeks to promote only his own interests against those of Athens.

Turning his attention to the question of legality concerning envoys, Demosthenes attempts to outline the legitimate bases for inquiry into an envoy's conduct. Drawing on ideals inherent to the rule of law, Demosthenes claims that the legitimate matters for inquiry into an official's conduct are first, that the report he delivered is correct; second, that the advice he gave was sound; third, that he followed the instructions that the ekklêsia gave to him; fourth, that he used his time well; and fifth, whether he was corrupt in 
discharging his duties (Dem. 19.4). He also claims that a citizen who acts as an official leaves himself open to scrutiny indefinitely, hoping to encourage the jury to ignore the gap between the crime and prosecution (Dem. 19.2). Demosthenes outlines a framework for scrutiny that he can legitimately claim as a rule of law, thereby constructing the boundaries within which he will interrogate Aeschines' conduct as an envoy, and ultimately as an Athenian citizen.

Demosthenes claims that Aeschines gave a false report, prevented him from relaying the truth to the ekklêsia, formed policies that went against Athenian interests, ignored instructions, wasted time when the city's opportunities were great, and took gifts and payments from Philip (Dem. 19.8). Importantly, Demosthenes claims to have had no knowledge of Aeschines' corruption at the time of the first embassy when the peace was made, thereby protecting himself from accusations of collusion (Dem. 19.13). Aeschines' wickedness therefore is his own, while Demosthenes portrays himself as the legitimate defender of the city's interests. To strengthen his claims, Demosthenes reminds the jury that "the lawgiver" precluded an official from receiving gifts of any kind (dora) as it renders his judgement unreliable (Dem. 19.7). Demosthenes conceives of bribery as an official receiving a gift, irrespective of whether the gift influenced the official's decision. All gifts to officials, therefore, are bribes.

Aeschines comes under suspicion for his perceived friendship with Philip. Aeschines returned from the first embassy to Macedonia claiming that 
he had persuaded Philip "to agree to everything that was in the city's interests regarding both the Delphic Amphictyony and everything else", and that he had secured the demise of Thebes (Dem. 19.20). Demosthenes, however, reminds the jury that he stood up at the ekklêsia claiming to have no knowledge of such discussions, and that Aeschines and Philocrates booed and jeered as he spoke (Dem. 19.23). The effect, then, was that Aeschines unrealistically, and purposely, raised the hopes of the dêmos about the effectiveness of the peace (Dem. 19.24). Demosthenes, in reporting the ekklêsia, reminds the jury that he had tried to warn them of Aeschines from the earliest possible moment, and that in highlighting Aeschines' turn around in policy, the jury will see Aeschines' friendship with Philip as the corrupting influence he claims it was (Dem. 19.25-27). Demosthenes then asks the jury to judge the friendship based on the outcome. If Aeschines' information was correct and the results he predicted occurred, then the friendship with Philip was, in effect, a well placed diplomatic one. However, if the outcome was the opposite of what Aeschines predicted, and Athens suffered shame because of it, then Aeschines is corrupt, and "...he changed his policy because of his own avarice and because he sold the truth for money" (Dem. 19.28). In the event, Athens suffered because of the peace, which highlights Aeschines as a self-interested and corrupt politician, who is the opposite of a good Athenian democratic leader.

Returning to accusations of corruption, Demosthenes separates himself once again from the other members of the embassy, attempting to show that the boule has unjustly chosen not to praise him for his conduct as an envoy. If 
everyone acted wrongly, then the boule is right not to praise him. However, if some acted rightly, then "...it would seem that the good envoys share in the disgrace caused by those whose conduct is wicked" (Dem. 19.32). Demosthenes achieves two purposes. First, he claims that the guilty remained silent, while the innocent loudly separated themselves from guilt (Dem. 19.33) and he has a decree read out to support this stance (Dem. 19.31). In doing so, Demosthenes marks the line between good and bad envoy, and proves himself justly deserving of the city's honours. Secondly, he highlights one of the motives for a citizen to take action against an official at a euthyna. The city chooses carefully to whom it allocates praise and blame. While it is shameful for the city to allocate honours to a corrupt citizen, it is unjust not to honour an otherwise blameless citizen. The process of euthyna should therefore assist the dêmos to distinguish the chrêstoi from the ponêroi. Consequently, the euthyna becomes a vehicle for the competition for honours at the hands of the law court jury. In deciding who deserves honours, the jury asserts its social and moral power, and the rule of law administers timê.

Demosthenes discusses the very purpose of holding a euthyna. The purpose is to ask what the envoy accomplished and reported and assess its veracity, at which point "if your report was true, you are safe; if it was false, pay the penalty" (Dem. 19.82). However, Demosthenes later turns the question toward the issue of intent, saying that if Aeschines simply mouthed off and made errors as a private citizen, then the jury should overlook his conduct. However, if Aeschines purposely deceived the ekklêsia as an envoy for the 
sake of money, then the jury must punish him (Dem. 19.182). Jury members will cast their votes "... in accord with the laws and decrees of the assembly and of the five hundred" (Dem. 19.179). In doing so, the jury become the fact finders of the case, the enforcers of justice, and legal guardians of the polis.

Aeschines' speech to the ekklêsia is a key factor in the euthyna, which allows Demosthenes to introduce his conception of dêmokratia. Demosthenes asks the jury "for what else should envoys be held accountable if not their speeches?" and claims that envoys are in charge of words and time (Dem. 19.183). He then replies that speaking falsely is the worst crime that someone could commit against the dêmos, as the very nature of dêmokratia requires citizens to base their decisions on what people tell them in speeches. Those who take bribes and favour the enemy, therefore, place in danger the entire city and its government (Dem. 19.184). Time then becomes important, as the democratic process is slow. While an oligarchy or a tyranny can make decisions quickly as few people have the opportunity for input, in a dêmokratia the boulê must discuss the issue at a predetermined time, followed by an ekklêsia held according to the laws, at which various politicians must spend time stating their positions and making their arguments on the issue (Dem. 19.15). With a decision made, the city must then allow time to gather resources for the venture, which means that an official who wastes time ruins the city's policy (Dem. 19.186). Demosthenes shows that dialogue lies at the very heart of dêmokratia and that the rich and powerful have constraints on what policies they can get the city to pursue. However, he also warns of the 
dangers of too much discussion leading to political paralyses in external affairs. Dêmokratia requires both words and actions.

To show that Aeschines is guilty of taking bribes, Demosthenes looks at two issues. First, Aeschines as an envoy received benefits from the very thing that has caused the city to suffer (Dem. 19.88). Second, Demosthenes looks at Aeschines' behaviour itself. While Athens discussed the terms under which the peace would proceed, Aeschines

opposed the speakers defending what was right, took money, spoke in support of the man who was bribed to move the proposal, and afterwards, having been elected to the embassy to secure the oaths, failed to carry out any of your instructions, destroyed the very allies who survived the war intact, and uttered lies of a magnitude and consequence that no one else has ever matched before or since (Dem. 19.94).

Aeschines shows the extent of his morally corrupt behaviour when he abuses a captive Olynthian woman and has her beaten while drunk at a symposium (Dem. 19.196-8). Demosthenes frames Aeschines' behaviour as hybristic. In favouring his own personal profits and potentially increased political power over the interests of the city, Aeschines endangers the city and its people. Aeschines' physis clearly opposes Athenian nomos, and Athens should not allow him to continue living in the dêmokratia. As judge, the jury makes a decision not only as to the facts of the case, but also the morality of the players, thereby authoritatively upholding the community's moral standard. The argument ultimately places unwritten/moral law above the written/political law. 
With Demosthenes' position on Aeschines' behaviour and the role of the jury established, he turns his attention towards the place of coercion in politics. Demosthenes claims that Athens does not force people to become politicians, but that they volunteer once they consider themselves capable of official responsibilities (Dem. 19.99). Politicians who achieve positive results will receive acclaim, whereas those who fail must face the dêmos (Dem. 19.100). Therefore, Aeschines cannot, as an excuse for his behaviour, claim the dêmos coerced him into an official position beyond his capacity. Demosthenes then suggests acquittal should the jury find that Aeschines acted out of ignorance or stupidity, or death should they find it was due to corruption (Dem. 19.101). Further, if Philip tricked Aeschines, then he should have owned up to it sooner (Dem. 19.104). The implication is that as Aeschines declared himself competent for the role of envoy, he cannot now claim to be unable to perform the role properly, and he must therefore have allowed Philip to corrupt him with bribes.

Further proof of Aeschines' corruption is in his failure to act against Philip when he had the opportunity. With suspicion of corruption, Demosthenes asked his fellow envoys to declare their innocence to charges of aiding Philocrates (Dem. 19.116-7). All declined, but Aeschines was the only one without a good reason not to do so, which shows his complicity (Dem. 19.118). Demosthenes uses the concept of timê against Aeschines by showing that no honest Athenian envoy would want an accusation against them to persist, proving Aeschines' guilt (Dem. 19.119). Demosthenes' argumentum 
ex silentio implies that time is a central part of the dispute, and a key factor in the minds of jurors. Lacking hard evidence of Aeschines' corruption, Demosthenes claims that Aeschines bears witness against himself. When Demosthenes requested exemption from a follow-up embassy, Aeschines stayed behind also to counter Demosthenes' influence over the ekklêsia (Dem. 19.23), implying that Aeschines' purpose was to prevent the dêmos from changing any of its decisions (Dem. 19.124). Demosthenes frames Aeschines as a manipulator of the dêmos whose corruption places the dêmokratia in danger by undermining its processes and institutions. Turning his attention toward the jury itself, Demosthenes argues that Athenian laws prescribe a harsh penalty for such conduct, and failing to uphold the law will bring Athens into disrepute among other Greeks (Dem. 19.133). Demosthenes invokes the language of the rule of law. The jury has the power to uphold the rule of law, and in doing so, it creates the perception that the Athenian dêmos rules through its laws.

Where the jury has the power to uphold the law, it also has the power to enforce a strong deterrent to others who may aspire to corruption through the self-interested use of power. Demosthenes claims that Philip would need people working for him in Athens, and claims that Aeschines is one of Philip's key people (Dem. 19.136). Taking the opportunity to kill Aeschines would secure two objectives for the dêmos. First, it ensures that no citizen in the future will think he can gain from selling himself to leaders such as Philip, securing the loyalty of the citizenry toward the dêmokratia. Second, it would 
render Philip unable to continue to use Athenian officials for his own purposes, knowing that individual citizens have no power over the dêmos (Dem. 19.137-8), securing the position of the demos as kyrios. Demosthenes, ostensibly upholding the interests of the dêmos, uses the topos of deterrence to have Aeschines punished severely and to act as a reminder for Athenians to focus on the greater Athenian good, rather than their own private interests.

Demosthenes contrasts the position of Thebes to that of Athens. Thebes, which sent envoys who maintained integrity, gained greatly from peace where they were previously suffering (Dem. 19.141-45), whereas Athens went from prosperity to misery through the corruption of Aeschines (Dem. 19.149). Underlying Demosthenes' depiction is the image of the hybristês who brings about atê. The trouble facing Athens, therefore, is a moral punishment brought about by the man now on trial, and the jury must cleanse the city of the moral corruption through legal procedures and punishment. In enforcing the rule of law, the jury adopt the traditional role of the guardian of the laws (nomophulax), and uphold the customary link between Athenian law and the gods.

Demosthenes draws a sharp contrast been himself and the other envoys. He vehemently opposed Philip from the start, while Aeschines was conspicuous in opposing Demosthenes (Dem. 19.156-7). The other envoys wasted time, surrendered Thracian territory, failed to carry out official instructions, ignored the city's interests, and delivered a false report on returning to Athens (Dem. 19.161). They proved their devotion to Philip by 
staying still when Athens needed them to move hastily, and moving when Athens needed them to stay still (Dem. 19.165). Further, they all received offers from Philip while at Pella (Dem. 19.17). Their actions, therefore, are responsible for the disastrous outcome. Demosthenes, on the other hand, personally ransomed many captives (Dem. 19.170-1), and shows that “...whatever was under my control during the embassy turned out for your benefit, but whatever these men, being the majority, controlled, ended in utter disaster" (Dem.19.173). Demosthenes attempts to show himself as the chrêstos who exceeds the requirements of Athenian law with a free and generous spirit, but who is subordinate to and constrained by the power of the dêmos through democratic process. In doing so, he upholds the dêmos as the legitimate sovereign body, but also hides behind the democratic process, defined by nomoi, placing a question mark over the efficacy and efficiency of demotic power.

After a brief recap of his arguments, Demosthenes returns his focus to the jury itself by reminding them of their duty to vote "...in accord with the laws and decrees of the assembly and of the five hundred" (Dem. 19.19). He claims that, while on the embassy, Aeschines acted contrary to the laws, decrees, and justice, making the specific accusation that he was responsible for the loss of Phocis, which controlled Thermopylae, and Thrace, which controlled the Hellespont, proving his utter disregard for Athenian interests (Dem. 19.179-80). The situation that has led to citizens being able to behave in such a manner while officials, is the lack of control taken by the jury in 
dealing with such miscreants. Demosthenes blames a lack of foresight on the part of the dêmos to guard against upcoming trouble, ignoring anything that is not imminent, by which time it is too late to act effectively (Dem. 19.181). The jury, therefore, has the opportunity to take matters into their own hands and punish Aeschines in a bid to secure the future of Athens against impropriety and the ensuing disaster.

In a defensive mode, Demosthenes pre-empts Aeschines' argument that he too was complicit in the corruption. Demosthenes uses a simple argument that even if he were complicit, Aeschines would still be guilty (Dem. 19.202), and claims that an honest defence would argue either that the dishonest acts did not occur, or that they benefited the city (Dem. 19.203). The acts, however, did occur, and the city has not benefited in any way (Dem. 19.204). Further, Demosthenes opposed Aeschines from very early in the events, which shows he was not complicit (Dem. 19.207). Finally, when Demosthenes began to make accusations against Aeschines, Aeschines simply attacked Demosthenes, rather than defending the accusations (Dem. 19.210). He then asks the jury directly, “...what defendant would prefer to level accusations if he were able to mount a defence?" (Dem. 19.213). In a short passage of his speech, Demosthenes attempts to remove Aeschines' ability to place the focus of the trial onto him, but to keep Aeschines firmly as the focus and show that any attempt by Aeschines to avoid the focus will prove that he is guilty.

Demosthenes attacks head on the potential accusation of being a sykophant. The test, he claims, is that he would have gained more from taking 
Philip's money than he would have from taking the present case (Dem. 19.222). Instead, he brings the case with a view to the future through the established mechanism of the euthyna before a jury, in a bid to show the commonality of interests between himself and the dêmos, and to show the divergence of interests between Aeschines and the dêmos.

The deterrent effects of the jury decision and justice generally come together with Demosthenes' self-interest in an enlightening way. Demosthenes makes it clear to the jury that in failing to honour him for his propriety, the jury effectively punish him. Future officials will ignore propriety, as there is no better reward for it over impropriety. Severe judgement of Aeschines will therefore have two effects. First, it will show future officials what the standard is, and what they can expect if they fail to meet it. Secondly, Demosthenes effectively argues for a doctrine of precedent. Jury courts in Athens had no binding power over future juries, and there was consequently no binding precedent value of legal decisions. However, Demosthenes says to the jury "you are not merely judging these men today, no, you are also enacting a law for all time hereafter..." (Dem. 19.232). The claim here asks the jury to become legislators of a law that will henceforth bind all city officials, and demand that they act honourably in the interests of the dêmos. Such a law, however would not be a written law, but would add to the unwritten koinos nomos rather than act as a strict legal precedent. Justice requires that the jury create a legal standard, which reflects a vision of the jury as the legitimate, and perhaps the pre-eminent, power in the Athenian dêmokratia. Nomos links with 
justice, honour, and the interests of the dêmos through the forum of the dikasteria, and the confluence of factors hints that the rule of law, despite its insistence on written standards, is in fact negotiable according to customary standards.

Having attempted to endow the jury with extra legal authority and powers, Demosthenes emphasises the necessity for just action. He points out that, although the ballot is secret, the gods will know which way the jurors voted, and therefore who upheld justice (Dem. 19.239). The choice for jury members then becomes either to offer Aeschines a favour by freeing him, or to act according to justice by punishing him (Dem. 19.240). Demosthenes points to the effort involved in making the vote. Prudence, Demosthenes claims, takes no more trouble than imprudence, as it takes the same amount of time to vote either way (Dem. 19.270). However, the force of Demosthenes' speech is such that to vote for Aeschines will expose not only the individual jury member to retribution of the gods, but also his family, and ultimately the entire city. Justice and prudence require Aeschines' conviction. Demosthenes attempts to coerce the jury into voting according to his version of Athenian law, which draws on a traditional moral ideal and hints at ancient thesmoi rather than democratic nomoi.

To establish an authoritative standard of justice upon which to judge Aeschines, Demosthenes looks to Aeschines' behaviour itself. Referring to an earlier trial involving Aeschines and Timarchus (Aesch. 1), Demosthenes says, "surely it is fitting that others should exploit against you, Aeschines, the very 
standards of justice that you employed in prosecuting Timarchus" (Dem. 19.241) ${ }^{283}$ In a form of the golden rule, Demosthenes asks the jury to enforce the standard that Aeschines had enforced against Timarchus, especially in respect to the effect of rumour (Dem. 19.243-4). Instead, he draws on a general principle to offer jury members a standard upon which to judge Aeschines; the standard he himself has applied in judging other citizens. Demosthenes uses an objective measure upon which to judge Aeschines, but in establishing his moral concept, he offers a subjective basis for the jurors to judge. Again, Demosthenes draws on precedent and its connection with punishment, highlighting the important function of the jury as the body to decide on issues upon which the law does not proclaim any authority, and as the legitimate forum for the pursuit of justice and vengeance.

Building further on precedent, Demosthenes refers to two previous situations in Athens. First, Demosthenes uses the example of Callias who secured a peace treaty with the Persian king, only to face a fifty-talent fine and possible execution for accepting gifts (Dem. 19.273). The envoy acts as a representative of the dêmos, and the treaty is therefore due to the ability of the dêmos rather than the individual, whereas taking gifts is a sign of an individual's corruption (Dem. 19.274). Second, Demosthenes compares Aeschines to Epicrates, an envoy executed for ignoring instructions, making false reports to the boule, defaming the allies, and accepting bribes (Dem. 19.277-9). It is therefore incumbent on the jury to uphold earlier standards and punish Aeschines severely irrespective of any charis it may feel it owes

\footnotetext{
${ }^{283}$ MacDowell (2000) translates the passage as stating “...the same rule of justice...”.
} 
Aeschines for past benefactions. To emphasise the necessity, Demosthenes uses Aeschines' own argument that “... a city that does not use muscle against criminals is of no use, nor is that state where clemency and influence outstrip the laws..." (Dem. 19.283). Dêmokratia requires the jury to prevent individuals such as Aeschines from being able to exert undue influence on demotic decision-making, even where it has a sense of obligation toward the citizen concerned. In doing so, the jury takes control of traditional institutions such as charis, administering it through the rule of law.

Following on from the issue of juridical power, Demosthenes introduces the idea of fear. Demosthenes claims that he does not fear Philip, despite his potential to lay waste to Athens, so long as the jury plays its proper role as guardian and protects the dêmos from politicians who seek to exert influence in favour of Philip without fear of punishment (Dem. 19.289). Returning to a familiar topos of the hybristês Demosthenes says, "there is nothing, absolutely nothing, that warrants greater vigilance than letting some individual rise above the many" (Dem. 19.296). Although many have become powerful by speaking in the ekklêsia, Demosthenes claims that no one has become more powerful than the court, the laws, or the jury oaths (Dem. 19.297). In allowing Aeschines to go unpunished, the jury will encourage hybris by allowing others to think they can become greater than the dikasteria, the laws, and ultimately the dêmos and its treasured dêmokratia. The dikasterria, through the force of the rule of law, therefore, is the legitimate protector of the polis. Demosthenes ends his speech upholding the jury as the 
kyrios of Athens, and demands a hostile reception for Aeschines and his arguments.

Aeschines opens his speech by asking the jury for a friendly hearing (Aesch. 2.1). He confirms Demosthenes' argument that anyone who excites the jury on bribery charges should avoid such conduct (Aesch. 2.3), and proposes a penalty of death should he be convicted of bribery (Aesch. 2.5). However, he then turns the jury expectations around when he says,

If a man who convicts himself by failing to appear is guilty, then a man who acquits himself by handing himself over to the laws and his fellow citizens is innocent (Aesch. 2.6).

Aeschines offers a feint to gain the jury's empathy by drawing on the idea of the presumption of innocence, trying to show his desire to prove himself innocent of the charges that Demosthenes has laid simply by appearing in court.

One of the key devices that Aeschines uses to defend himself is the accusation that Demosthenes is inconsistent. Demosthenes treats Aeschines with contempt, accusing him of various forms of baseness, then makes arguments against him "...as if he were charging Alcibiades or Themistocles" (Aesch. 2.9). Demosthenes likens him to the tyrant Dionysus, but places the blame for events on Philip's weapons (Aesch. 2.10). The result is that everyone but Demosthenes is a traitor, while he is the only one with concern for the city (Aesch. 2.8). Consequently, due to Demosthenes' trickery, it is difficult to counter-argue his speech properly without danger of unwittingly committing slander (Aesch. 2.11). Aeschines, in a bid to counter 
Demosthenes' connection with the dêmos' interests, immediately attempts to establish affinity with the jury, undermining Demosthenes' speech as one that elevates the speaker unrealistically over the dêmos, and which therefore cannot be trusted.

Aeschines uses Ctesiphon and Aristodemus as examples of Demosthenes' inconsistency. Ctesiphon returned from Philip to say that peace was possible. Philocrates then proposed a decree, passed unanimously, that "Philip should be allowed to send a herald and envoys here to speak of peace" (Aesch. 2.13). The proposal became subject to graphê paranomôn, Demosthenes agreed to defend the accusation on behalf of Ctesiphon, and the accuser lost with less than one fifth of the votes (Aesch. 2.14). Aristodemus made an assertion in the boulê and ekklêsia that Philip was well disposed to Athens and Demosthenes, rather than opposing Aristodemus, moved that he receive a crown (Aesch. 2.17). Philocrates then drafted a decree to send an embassy to Macedonia, and nominated Demosthenes for a position as envoy (Aesch. 2.18). Aeschines demonstrates that Demosthenes supported the peace from the beginning, and that the initiative for the peace came from Philocrates and Demosthenes (Aesch. 2.20). Later, Aeschines has decrees read to show that Demosthenes not only supported the embassy discussing peace, but also argued to extend discussions to include alliance with Macedonia (Aesch. 2.54, 61). Consequently, Demosthenes' attempts to separate himself from the peace are suspect, and show him to be untrustworthy. 
Aeschines makes an argument based on the nature of the envoys that relates directly to the dêmos' use of the election of officials. Athens elects citizens as officials who are of sound character and have proven themselves capable politically. By all accounts, the men sent on the envoy were "good" Athenians. However, by Demosthenes' account, they became corrupt and turned traitor on arriving in Macedonia (Aesch. 2.23). Demosthenes, on the other hand, travelled to Macedonia bragging of all he would do and say to Philip, only to fumble and give up speaking when he arrived (Aesch. 2.34-5). The jury should therefore not easily accept that the nature of most of the envoys became corrupt, while Demosthenes evidently has good reason to try to avoid investigation of his own behaviour.

Aeschines then deals with the accusation that he changed his position on the peace. Demosthenes claims that Aeschines opposed Philocrates' peace at the initial reading, but supported it at the second reading on the following day (Aesch. 2.63). Such a change could suggest a corrupting influence on Aeschines. ${ }^{284}$ Aeschines opposes the claim as impossible (Aesch. 2.64). Decrees show that there were no speaking rights allowed at the second reading, which proves Demosthenes' account is unreliable (Aesch. 2.65). While decrees remain the same over time, it is the very hallmark of the sykophant to change his argument according to the situation of the moment (Aesch. 2.66). Aeschines deftly achieves a double purpose with his argument. Demosthenes has clearly changed his position according to the situation, which implies he is a sykophant. Aeschines, on the other hand, has not

\footnotetext{
${ }^{284}$ See Dem. 19.13-16; Carey (2000), 114 n87.
} 
changed his position at all, and he would gain only contempt from changing his position. Aeschines conveniently avoids the potential gain from Philip should he assist the Macedonian cause, and in doing so maintains confluence between his and the dêmos' interests.

Despite claiming that the envoys became corrupt during the first embassy, Demosthenes did not lay charges after their return to Athens (Aesch. 2.96). He did, however, make general accusations, and it is due to these accusations, Aeschines claims, that the other envoys kept away from Demosthenes (Aesch. 2.97), placing under question Demosthenes' connection between the isolation and the envoy's corruption. He then reminds the jury of Demosthenes' reputation as a young man of being a sykophant (Aesch. 2.99). Subsequently, Aeschines claims that, when Demosthenes was finally able to speak to Philip, he slandered the other envoys and claimed he supported Philocrates' decree (Aesch. 2.109), claimed that he tried to bridle those who opposed the peace (Aesch. 2.110), and failed to mention any of the most important topics (Aesch. 2.114). Far from being the stable and honourable character he portrays, Demosthenes is actually himself corrupt and a sykophant and the jury cannot accept his argument about Aeschines. Demosthenes possesses an unstable and untrustworthy character not fitting in a dêmokratia.

Aeschines then turns toward the question of responsibility. Aeschines tries to show the jury that he had Athenian interests and justice at heart, was 
responsible only for his speech, and that the result was due to Philip and Fortune, leaving the question to the jury

Well, then, who deserves praise, the man who had no intention of doing any good, or the man who left nothing undone that was in his power? (Aesch. 2.118)

Aeschines shows the jury that he was ultimately unable to affect the desires of the dêmos, due to the gods and the superiority of Philip's power, rather than negligence, corruption, or inadequacy, on his part.

According to Demosthenes, Aeschines and Philocrates prevented him from telling the truth to the ekklêsia after the first embassy (Aesch. 2.121; Dem. 19.8). However, on return, Demosthenes gave his account to the ekklêsia and lauded Aeschines' speech to Philip (Aesch. 2.122). Aeschines then attacks Demosthenes' argument in a clear and efficient way, saying to the jury

Yet what better opportunity than that could he have had to expose outright any lie I was telling the city? You say that on the earlier embassy you did not realise I was part of a plot against the city, that you became aware on the second embassy, the one where you clearly supported me. You make accusations about the first embassy while simultaneously claiming you have no complaint, and you base your charge on the embassy for the oaths. Yet though you criticise the peace, it was you who proposed alliance as well. And if Philip deceived the city, his purpose in lying was to gain the peace that was to his advantage. Well, then, the earlier embassy was critical for this, but when the second embassy took place, everything had been settled (Aesch. 2.123).

Aeschines destroys Demosthenes' credibility, using his own words and actions against him. Aeschines shows the jury that Demosthenes has been an 
unreliable witness on behalf of the demos, and lied to protect his own selfinterest.

Aeschines goes to considerable effort to deal with Demosthenes' argument based on rumour. Creating a distinction between common report and rumour, Aeschines states that, Common report has no connection with slander, but malicious accusation is slander's sister...Common report is when a mass of citizens of their own accord with no ulterior motive talk of an event as real; malicious accusation is when one individual presents an accusation to the general public and slanders someone at every assembly and in Council. We sacrifice to report publicly as a goddess, while we bring charges against sykophants publicly as criminals (Aesch. 2.145).

In terms of a direct defence, Aeschines' argument is effective. Demosthenes used Aeschines' own argument from a previous case to show that rumour can and should be trusted, and that rumours were rampant of Aeschines' corruption (Dem. 19.243-4). Aeschines then attempts to create a redefinition of rumour to avoid its affect. The argument is important in two ways. First, it is a clear case of a party to a lawsuit redefining a term to suit his argument. Second, the emphasis that Aeschines placed on the rumour argument suggests that rumour is an aspect that the jury members will draw on when making their decision to vote. Consequently, what at first appears as an irrelevant side issue proves to be an important extra-legal factor. Aeschines uses rumour to import Athenian tradition into his legal case.

In response to the question of being a traitor, Aeschines uses a simple empirical argument. His father, an athlete, belonged to a respected phratry, 
was exiled by the Thirty, and took part in the restoration of the demokratia (Aesch. 2.147). All relatives on his mother's side are freeborn citizens (Aesch. 2.148). His brothers are important and well-respected citizens who support him (Aesch. 2.149). He then presents his three children to the jury and asks Do you think I would have betrayed to Philip not just my country, the friends with whom I associate, and my right to share the temples and graves of our ancestors, but these, the ones I love most of all the people in the world, that I would have set more store by his friendship than their safety?...It is not Macedonia that makes men good or bad but their nature (physis). We are not different men now that we are back from the embassy but the ones you sent (Aesch. 2.152).

Aeschines' premise is that an Athenian would value the Athenian traditions and nomoi over the possibility of safety and wealth in another state. The more respectable the connection with the polis, the more likely an Athenian is to place those traditions above all other possibilities. Aeschines' introduction of "athletic pursuits" is suggestive of aristocratic culture. ${ }^{285}$ His physis is in accord with Athenian nomos. With his traditional Athenian credentials asserted, Aeschines therefore relies on the jury also to place great value on those connections and in doing so refuse to accept he could possibly be a traitor.

In a bid to show his opponents as being opposed to the Athenian state, Aeschines provides the jury with his version of Athenian history up to the time of the restoration of dêmokratia in $404 \mathrm{BC}$ (Aesch. 2.172-77). He makes an implication that some citizens took advantage of the war to legitimise their

\footnotetext{
${ }^{285}$ Ober (1989): 282-3.
} 
place in Athens, and that those people are "...trying to destroy the peace that keeps dêmokratia safe, while they champion the wars that destroy dêmokratia" (Aesch. 2.177). He then makes the direct accusation that these people have come against him, and are seeking to destroy him. The insinuation is that Demosthenes, a foreigner by blood, is one of these people, that he does not actually belong in Athens as a citizen, that he opposes peace not for Athens' benefit but for his own interests, and that those interests oppose the interests of Athens. ${ }^{286}$ His physis is in serious opposition to Athenian nomos. Where such is the case, the jury should not allow Demosthenes to pursue Aeschines successfully.

Finally, Aeschines makes a formal supplication to the jury, introducing family members and asking the jury to "...give careful thought to them and not hand them over to their enemies or to this unmanly and effeminate person" (Aesch. 2.179; cf Dem. 19.310). His plea to the jury links with ancient religious norms, and relates to his earlier command for the jury to "...purify the assembly!" (ten ...ekklêsian kathairete) (Aesch. 2.158). Aeschines shows the jury that in punishing him, his oikos will suffer, perhaps to the point of ruin. ${ }^{287}$ Through his act of supplication, Aeschines publicly acknowledges the superior power of the dêmos and surrenders his timê. ${ }^{288}$ In doing so, he also exaggerates the timê of the jury, and acknowledges its discretion in the situation. ${ }^{289}$ Out of necessity, Aeschines depicts the prosecutor, Demosthenes,

\footnotetext{
${ }^{286}$ Ober (1989): 269-70.

287 Johnstone (1999): 112.

288 Johnstone (1999): 123.

${ }^{289}$ Johnstone (1999): 124; Gould (1973): 94.
} 
as someone from whom he needs protection from the jury. ${ }^{290}$ As a threat to Athenian oikoi, Demosthenes threatens the entire polis. The jury must banish him from the city in a ritual purge, by way of democratic legal decisionmaking according to Athenian law in the procedure of euthyna, and in doing so uphold the rule of law in Athens. Pity for Aeschines, therefore, should translate as acquittal for the present charges.

An important aspect of the case between Demosthenes and Aeschines is the place of personal attacks. Both litigants strew their speeches with outright insults and abuse towards the other to a great extent. Such enmity relies on the central place of time in the social psyche, which makes it important in deciding between competing individuals. Personal attacks played almost no role in Demosthenes' case against Leptines, but the issue of timê and formal honours was central to the case overall. Demosthenes' case against Meidias contained some severe personal attacks, with a strong question of timê involved, based around the ability of one citizen to dishonour the entire polis. However, in the present case, the attacks reach a scale that exceeds anything that previously occurred. Both parties use personal attacks liberally, and both aim to bring the other into disrepute in a bid for their own argument to win in the vote. Some examples are enlightening.

Demosthenes claims that Aeschines is a 'blabbermouth' (tis ho eklalesas) (Dem. 19.42), a "scoundrel, a blasphemous villain, and a clerk" (Dem. 19.95), a "piece of trash" who is "fierce when he drinks" (Dem. 19.198), that he hung around with drunken revellers as a child (Dem. 19.199),

\footnotetext{
${ }^{290}$ Johnstone (1999): 124.
} 
that he took bribes as a clerk and is now a freeloading bit part player (Dem. 19.200), a bootlicker and a liar (Dem. 19.201), a wicked sophist and a fiend (Dem. 19.250). Aeschines states that Demosthenes is "an unbearably tedious man" (Aesch. 2.21), full of arrogance (huperephania), malice, cowardice, and mean spiritedness (Aesch. 2.22), deceptive (Aesch. 2.57), descended from Scythian nomads (Aesch. 2.78; 180), a pervert (kinaidos) ${ }^{291}$ with an unclean body (Aesch. 2.88), effeminate, not of free birth (Aesch. 2.127), and brings down the curse of heaven upon his own head (Aesch. 2. 158).

Demosthenes and Aeschines both make personal attacks freely. Both litigants are aware that they must not only argue as to the facts of the case, but also promote themselves as the archetypal Athenian, while showing their opponent to be the paradigm villain. The image is one of two rival citizens competing for honour. The methods they use to try to become the recipient of honour are important for what it reveals about the nature of Athenian juries and the kinds of aspects they looked to in litigants. Rather than simply assessing the facts of the case, it is clear that the juries also looked to the character of litigants as a form of forensic evidence in cases based on legal actions that found their roots in character traits. Honour must only be bestowed upon those deserving of it, and the power of the dêmos must be central to the question of who should receive, and who should bestow, honour. In the official realm, character is of the greatest importance, as the dêmos perceive that a good character will ensure that its desires are fulfilled, its wishes carried out,

${ }^{291}$ Christ describes the use of kinaidos to mean a 'kept boy', Christ (1998): 96. 
and its interests protected. Demosthenes shows that bribery consists merely of an official receiving gifts, especially when linked with a failed policy, and proceeds to insinuate that Aeschines did in fact receive personal gifts from Philip while an envoy on behalf of Athens. Alternately, Aeschines attempts to show that he did not, in fact, receive gifts, but, more importantly, that he would not accept gifts from Philip, is not the kind of person who would accept gifts from Philip, and that his interests, like Athens', are served best by him refusing to accept gifts from Philip. Consequently, in such a case as a euthyna, in which an official's conduct comes under severe scrutiny, the question of character is integral to the interrogation, and personal attacks are therefore a fundamental feature of the dispute. In securing the integrity of Athenian character, litigants ensure the strength of the dêmos through the power of the jury court by way of upholding the democratic rule of law. 


\section{Conclusion}

From the late seventh century, Athenians showed a desire for written laws. Initially they took a simple form, reflecting long-held ideals of right and wrong, with the thesmoi of Solon drawing on traditional morality. Thesmoi did not always contain sanctions, but often relied on religious understanding to contain the threat of punishment. Good people would be rewarded for their obedience to the gods, and obedience to the laws was a natural corollary to such obedience. Bad people suffered for their crimes, cursed by the gods and set aside for harsh punishment. Hybris, for example, would end in atê, and if it was a leader who committed the hybris, then the whole community would suffer at the hands of the gods. To ensure eunomia, there was a need to ensure leaders pursued the good of the community. Laws, therefore, needed to apply to all citizens. With the promise of retribution, self-interest demanded obedience to the gods and the laws. Enforceable laws helped to rationalise the self-interest of individual citizens, which eventually promoted the wider good as a political goal.

Thesmoi fulfilled the initial desire to have written law. However, as the political situation in Athens developed, so did the requirements for laws. After the removal of tyranny at the end of the sixth century, isonomia became a political topos. In dealing directly with the dêmos and opposing an elected leader, Cleisthenes helped the emergence of a more democratic political environment. As a result, Athenians saw the need for law to take a different 
form. Nomos and psêphismata became the prevailing form of law throughout the fifth century, though in the common perception there was little difference between them. The key fact is that nomoi and psêphismata became the law of the dêmos under dêmokratia, where the laws were a product of community debate and processes, and open to general scrutiny. The importance Ostwald's places on the dêmos' laws supports his argument upholding the sovereign dêmos. Democratically made law became increasingly authoritative due to its place as a product of the dêmos, but remained subordinate to the will of the dêmos generally. The essential factor in Athenian democratic law was the ability of the dêmos to engage in open discussion on the issues involved.

The place of dialogue in Athenian law and politics highlights an important aspect of the Athenian polis. Traditionally, elites competed for leadership among themselves. As landed elites, they possessed a sense of entitlement, and acted accordingly. With leadership and leadership connections, elites had control, or at least a strong influence, over law and politics generally. Power, therefore was held tightly among certain groups within the polis. One of the key aspects to elite values was the place of time, which made up a part of the competition for leadership. To be an elite leader meant manifesting a strong sense of traditional elite values. Leaders became those who had the greater share of such values, and who could sustain strong competition. However, under dêmokratia, the competition for power changed. As the political sphere expanded, the pool of competitors followed suit. Rather than being tightly held, power became es meson, in the middle, and open to all 
citizens with sufficient means to compete. Further, the dêmos itself became the adjudicator of competition, particularly through the dikasteria. As the legitimate dispute resolution body, the dikasteria also became the ultimate conferrer of timê. Social and political rivals then began submitting disputes to the dikastêria, thereby upholding it as the legitimate body for establishing timê. The dêmos took control of traditional mechanisms through the submission of elites to its authority in the dikasteria. The rule of law therefore established a framework for citizens to formulate disputes, and in which to resolve questions of timê.

The resolution of disputes was central to Solon's establishment of eunomia. Isonomia, which became the key political goal after the fall of the tyrants, did not exclude eunomia, and in fact helped to define the principle. In effect, good government required political equality. Dêmokratia took over from isonomia, and was the term used for the politeia throughout the fifth and fourth centuries. Following further tyranny, however, the rule of law helped to define more clearly the requirements of government. It was no longer sufficient for government to rely purely on broad political principles. Previous attempts had eventually erupted into stasis and ended in tyranny. The rule of law then became a way to establish a legal framework for Athens, establishing the law as above even the momentary whim of the dêmos itself. It also defined the jurisdiction of the dikasteria more clearly, which established better legal processes generally. Accountability of the dêmos and its individual members was enhanced through the clarification of political principles and the 
establishment of a legal framework. Hence, the rule of law existed in the Athenian dêmokratia in a functional way of establishing checks and balances on the dêmos and its processes. It also formalised the dêmos' power over the polis. However, other aspects to the rule of law existed that take it outside the positivist legal framework, and ultimately prove the positivist model insufficient to evaluate the Athenian dêmokratia and its legal system.

The dikastêria, as the final arbiter and court of last resort, both confirmed and created the Athenian sense of identity. The dêmos was a selfdefined body, as Ober shows. That self-definition, however, was not something static. In the ekklêsia, through political speeches, and in the dikastêria, through legal speeches, the boundaries of Athenian identity were being continually re-negotiated. The strong sense of tradition established a conservative bias, but there was always room for innovations. In the case studies analysed above, the Athenian identity comes under continual question. Leptines, through the removal of ateleia, isolates Athens from its honourable traditions of the past. In re-establishing the ability to grant honours, Athens therefore reengages with the timê associated with the past. Meidias' hybris undermines the Athenian sense of equality at every level. The case highlights the possibility for social, political, and legal, issues to come together in the dikasterria, and the place of the rule of law as the mechanism for ensuring social security. Aeschines partook in Macedonian social custom, and abused traditional Athenian custom in his treatment of an Olynthian girl at a symposium. In all instances, litigants hold up an individual against an 
imagined ideal of Athens and Athenians, and ask the jury to judge accordingly. Consequently, the process continually questions what is important to Athens, both in the sense of the imagined community, and in the day-to-day socio/political sense. Athenian socio/political identity, therefore, was a constant process of re-negotiation, and the dikasterion was one of the key arenas for such debates. Central to the references to identity and tradition were questions of socio-political power.

Ober argues that power in Athenian dêmokratia had no central locus. Power was es meson, in the middle, and contestable. Isonomia, isêgoria, and eleutheria meant that the competition was open to all citizens, though equal outcomes were not guaranteed. The dêmos held political and legal power, and conferred it upon people or institutions as appropriate. However, Ober ignores the continued place of coercion in the Athenian polis. Laws often stated penalties, sometimes severe and occasionally capital. Disobedience of the laws could bring about serious consequences, showing that Athens reserved the right to coerce people into obeying its laws. The disobedience of an individual brought about the collective retribution of the polis. To follow Ober's line of thought, though not accepting his argument in full, the Athenian constitution was fundamentally discursive, but retained the use of coercive force throughout.

Traditional elites had always contested among themselves for power through a range of arenas, and the demagogue proved that new ways of acquiring and contesting power could emerge under the dêmokratia. A key 
aspect of contestability was the place of timê. For people to accept a leader, he must have timê, and this could often be measured against an opponent. As Cohen argues, in the dêmokratia such competition continued in the arena of the dikastêria. His argument states that jury trial was an agôn, and timê among elites was what was at stake. A citizen who takes a graphê against another for a crime committed against the entire polis is therefore seeking self-interest by increasing timê. The dikastêria was well attested as the authoritative vehicle for deciding on timê, but Cohen's argument is ultimately unsatisfactory. Individual litigants may have been seeking the increase of timê in taking a case to the dikasterria. However, it is too long a bow to draw to say that this was the main function of the dikasteria, or the main motivation in taking a case.

While examples undoubtedly exist of litigants taking cases for political purposes, this was not the only reason. In the law court cases available, there is normally a reference to the law in an attempt to show that the opponent has broken Athenian law. Such arguments draw on the language of the rule of law, and support it in its formal sense. There is then often a series of attacks on the opponent in an attempt to show him as a bad Athenian. These often include strong character assaults that seek to portray the opponent as ponêros, and a variety of self and family praise meant to depict the speaker as chrêstos. The more severe the rivalry between the litigants, the more severe such attacks tend to be. Consequently, the dikastêria became a place in which litigants could have a fellow Athenian assessed for not only their obedience to Athenian nomos in its positive sense, but also how their character equated with Athenian 
nomos in its customary sense. This position largely supports Cohen's argument. However, while litigants were able to frame the terms of reference, the disputes were no longer according to their own rules. Submitting to the dikastêria meant submitting to the rules of the dêmos, which withdrew the disputes from the arena of elite feud under traditional rules. Ultimately, law court cases were not so much feud based, as they were social, legal, and political disputes according to the rule of law.

Athenian citizens had a range of legal actions open to them, and democratic principles allowed all citizens to take legal action even against elite citizens. Isêgoria meant that poor citizens could engage in dialogue with wealthier ones, and isonomia meant that the poor could actively participate in politics. Neither the dikastêria nor the ekklêsia were avenues purely for the wealthy, but places for public discourse, which, as Ober asserts, is the basis for Athenian dêmokratia. Whether the poor actually did use these institutions, however, is unknown. Cohen's argument assumes to a degree that these institutions effectively excluded the poor, allowing the wealthy elites to use them for their own purposes so long as they represented their self-interest as identical to that of the dêmos. The difficulty lies in establishing evidentially who the actual users of the dikasterria were. Litigants avoid depicting themselves as wealthy, but they also try not to appear to be poor. Cohen's position therefore is based on an argumentum ex silentio in that he fails to see evidence of poor litigants and assumes they did not exist. While a number of litigants are known to be wealthy elites, and some information is available 
about particular cases in terms of motivation, neither motivation nor financial status of individual litigants can be established from analysis of the law cases alone.

In all three cases studied, the orators follow the process outlined. Leptines proposed a law that conflicts with another law and in doing so has undermined Athens' timê, distancing it from its noble and glorious past. Due to a technical issue, Demosthenes fails to attack Leptines personally, which may support an argument that he had a genuine objection to the proposal based in law. Meidias assaulted Demosthenes in a public place, but in doing so while Demosthenes was acting in an official capacity Meidias shows contempt for the dêmos as a whole, which highlights his hubristic nature. Hybris has its roots in ancient tradition where it brings destruction of the polis from the gods. Consequently, in punishing Meidias, the dikastêrion purges the polis of someone who is unclean and takes on the traditional role of the nomophulax. Aeschines was elected as an official to represent Athens, and used his position to further his own interests. In doing so, he undermines the very nature of dêmokratia through the ease with which he deceives, and his readiness to uphold private interests over public interests. Whereas a dêmokratia is built on open and honest discourse, Aeschines introduces dishonesty to Athenian politics because of his bad and self-interested nature.

That power and honour were so readily contestable and came under the judgement of the dêmos shows that Athenian dêmokratia existed in more than just name. Individual citizens could compete both for power and for timê. As 
in all settings of competition, the odds are stacked in favour of those who already possess the best of whatever the competition is based on. At Athens, elites understood the values and customs that underpinned democratic nomos. A democratic chrêstos obeyed Athenian law. However, elites also possessed the traditional trappings of the chrêstos, wealth and honour, and the valuation of the latter over the former. Elites of the fourth-century dêmokratia were from a wider range of backgrounds than those of the fifth century, which shows the strength and inclusiveness of Athenian dêmokratia. What allowed the stability to contain the stasis that tore Athens apart in the past, however, was the rigour of the debate within the dikasteria about what constituted Athens as a body politic, and the existence of the rule of law, which helped establish the place of legal structures for intrapolis disputes. The rule of law also guaranteed the place of tradition within Athenian law, and maintained a sense of surety in the Athenian sense of identity. Litigants in the Athenian dêmokratia therefore used the rule of law to establish their democratic credentials, to give themselves a lawful base for their legal cases, and to attack opponents in the hope of gaining political ascendancy. Consequently, the Athenian rule of law under dêmokratia, despite its positivist ideal, functions according to both written and unwritten laws.

The place of tradition in Athenian law emphasises the place of the dikastêria as the legitimate dispute resolution arena for elites. Cohen argues strongly that the Athenian dikastêria were simply arenas for the continued pursuit of personal enmity among elites. However, the dêmos expressed its 
will according to its interests through all of its institutions. Decisions were largely made according to its perceived interest, which shows the dêmos was a rationally self-interested body. Although elites may have used the dikastêria to pursue personal enmity, the jury voted according to its own interests. Consequently, the role of enmity as undermining the rule of law does not stand. In fact, in submitting their personal disputes to the dikastêria, Athenian elites helped to uphold the rule of law as a constitutional entity. As Demosthenes argues, the laws are not able to act on their own behalf, but need citizens to give them life. Ober's references to speech-act theory, therefore, are entirely appropriate in the Athenian context. Elites, who were in all likelihood the greater users of the dikasteria, gave life to the laws through speeches in the dikasteria. Consequently, the elite pursuit of personal enmity helped to establish the constitutional force of the rule of law through their use of the dikastêria. Ultimately, the rule of law in the Athenian dêmokratia upheld Athenian law, created a legal framework, and allowed personal and political disputes to be settled before they dissolved into stasis, offering the Athenian dêmokratia its most successful mechanism for creating social, political, and legal, stability. 


\section{Bibliography}

\section{Primary Texts}

Aeschines: C. Carey trans. (2000) (Austin: University of Texas Press).

Aeschylus: C. Collard trans. (2002): Oresteia (Oxford).

Alcmaeon: J. Longrigg, (1993) Greek rational medicine: philosophy and medicine from Alcmaeon to the Alexandrians (New York: Routledge).

Antiphon \& Andocides: M. Gagarin \& D.M. MacDowell trans. (1998) (Austin: University of Texas Press).

Aristophanes: J. Henderson trans. (1998): Acharnians, Knights (London: Loeb).

Aristophanes: J. Henderson trans. (200): Birds, Lysistrata, Women at the Thesmophoria (London: Loeb).

Aristophanes: J. Henderson trans. (2002): Frogs, Assemblywomen, Wealth (London: Loeb).

Aristophanes: J. Henderson trans. (2005): Clouds, Wasps, Peace (London: Loeb).

Aristotle: A. Sinclair trans. (1981), The Politics (London: Penguin).

Aristotle: J.H. Freese trans. (2006): Rhetoric (London: Loeb).

Aristotle: S. Everson ed. B. (1996): The Politics and the Constitution of Athens (Cambridge: Cambridge University Press).

Aristotle: C.J. Rowe trans. (2002) Nicomachean Ethics (New York: Oxford University Press). 
Bacchylides: G.O. Hutchinson trans. (2001) Greek lyric poetry : a commentary on selected larger pieces : Alcman, Stesichorus, Sappho, Alcaeus, Ibycus, Anacreon, Simonides, Bacchylides, Pindar, Sophocles, Euripides (Oxford: Oxford University Press).

Demosthenes: D.M. MacDowell trans. (1990) Against Meidias (Oration 21) (Oxford: Clarendon Press).

Demosthenes: D.M. MacDowell trans. (2000) On the False Embassy (Oration 19) (Oxford: Clarendon Press).

Demosthenes: D.M. MacDowell trans. (2004): Speeches 27-38 (Austin: University of Texas Press).

Demosthenes: H. Yunis trans. (2005) Speeches 18-19 (Austin: University of Texas Press).

Demosthenes: I. Worthington trans. (2006) Speeches 60-61, Prologues, Letters (Austin: University of Texas Press).

Demosthenes: J.H. Vince trans. (1962) Orations: 1-17 \& 20 (London: Loeb).

Demosthenes: V. Bers trans. (2003) Speeches 50-59 (Austin: University of Texas Press).

Dinarchus, Hyperides, \& Lycurgus: I. Worthington, C. Cooper, \& E.M. Harris trans. (2001) (Austin: University of Texas Press).

Herodotus: J. Marincola trans. (1996) The Histories (London: Penguin).

Hesiod: R. Lattimore (1959) Works \& Days (Michigan: University of Michigan Press). 
Hippocrates: W.H.S. Jones trans. (1923) On Airs, Waters, and Places (London: Heinemann).

Homer: R. Lattimore trans. (1962): Iliad (Chicago: University of Chicago Press).

Homer: R. Lattimore trans. (1991): Odyssey (New York: Harper Perennial).

Isaeus: M. Edwards trans. (2007) (Austin: University of Texas Press).

Isocrates: D.C. Mirhady \& Y.L. Too trans. (2000) Volume I (Austin: University of Texas Press).

Isocrates: T.L. Papillon, trans. (2004) Volume II (Austin: University of Texas Press).

Lysias: S.C. Todd trans. (2000) (Austin: University of Texas Press).

Pindar: G.O. Hutchinson trans. (2001) Greek lyric poetry : a commentary on selected larger pieces : Alcman, Stesichorus, Sappho, Alcaeus, Ibycus, Anacreon, Simonides, Bacchylides, Pindar, Sophocles, Euripides (Oxford: Oxford University Press).

Plato: E. Hamilton \& H. Cairns eds. (1961) The Collected Dialogues Plato of Including The Letters (Princeton: Princeton University Press).

Pseudo-Xenophon: R. Osborne (2004) The Old Oligarch: Pseudo-Xenophon's Constitution of the Athenians (London: London Association of Classical Teachers)

Solon: M.L. West trans. (1994) Greek Lyric Poetry (Oxford).

Sophocles: P. Roche trans. (2001): The Complete Plays (New York: Signet Classics). 
Thucydides: R. Crawley trans. R.B Strassler ed. (1996) The Landmark Thucydides: A Comprehensive Guide to the Peloponnesian War (New York: Touchstone).

Xenophon: R. Warner trans. (1979) A History of My Times (London: Penguin).

\section{Secondary Texts}

Anderson, G. (2005) "Before Turannoi were Tyrants: Rethinking a Chapter of Early Greek History." Clas. Ant. 24.2: 173-222.

Anderson, B. (2006) Imagined Communities: Reflections on the Origin and Spread of Nationalism (London: Verso, Rev. Ed.).

Austin, J.L. (1975) How to do Things with Words (Cambridge, Massachusetts: Harvard University Press).

Badian, E. (1971) “Archons and Stratêgoi." Antichthon 5:1-34.

Boegehold, A.L. (1963) "Toward a Study of Athenian Voting Procedure." Hesperia, 32.4:366-74.

Burke, E.M. (2002) “The Early Political Speeches of Demosthenes: Elite Bias in the Response to Economic Crisis." Clas. Ant. 21.2: 165-93.

Bury, J.B, \& R. Meiggs, (1975), A History of Greece to the Death of Alexander the Great (London: MacMillan).

Cairns, D.L. (1996) “Hybris, Dishonour, and Thinking Big.” JHS 116: 1-32.

Carawan, E. (2002) "The Athenian Amnesty and the 'Scrutiny of the Laws'." JHS 122: 1-23. 
Carey, C. (1994) "Rhetorical Means of Persuasion," in I. Worthington ed. Persuasion: Greek Rhetoric in Action (London: Routledge): 26-45.

Carey, C. (1996) "Nomos in Attic Rhetoric and Oratory." JHS 116: 33-46.

Carey, C. (2000) Democracy in Classical Athens (London: Bristol Classical Press).

Carey, C. (2004) "Offence and Procedure in Athenian Law" in E.M. Harris \& L. Rubenstein eds. The Law and the Courts in Ancient Greece, (London: Duckworth): 111-36.

Cartledge, P. (1996) “Comparative Equality” in Ober \& Hedrick: 175-86.

Cartledge, P. (2000) "Greek Political Thought: The Historical Context" in C. Rowe \& M. Schofield eds. The Cambridge History of Greek and Roman Political Thought (Cambridge: Cambridge University Press): 11-22.

Cawkwell, G.L. (1988) “ $\quad$ and the Areopagus.” JHS 108: 1-12.

Christ, M.R. (1990) "Liturgy Avoidance and Antidosis in Classical Athens." TAPA 120: 147-69.

Christ, M.R. (1998) The Litigious Athenian (Baltimore: The John Hopkins University Press).

Cohen, D.J. (1995) Law, Violence, and Community in Classical Athens (Cambridge: Cambridge University Press).

Connor, W.R. (1971) The New Politicians of the Fifth-Century Athens (Princeton: Princeton University press).

De Brauw, M (2002) “'Listen to the Laws Themselves:' Citations of Laws and Portrayal of Character in Attic Oratory.” CJ 97.2: 161-176. 
Dornum D.D. (1997) “The Straight and the Crooked." Columbia Law Review 97.5: $1483-1518$.

Fisher, N.R.E. (1992) Hybris: A Study in the Values of Honour and Shame in Ancient Greece (Wiltshire: Aris \& Philips).

Gagarin, M. (1986) Early Greek Law (California: University of California Press).

Gagarin, M. and D. Cohen eds. (2005) The Cambridge Companion to Ancient Greek Law (Cambridge: Cambridge University Press).

Galpin, T.J. (1983/84) "The Democratic Roots of Athenian Imperialism in the Fifth Century B.C.” CJ 79: 100-09.

Gould, J. (1973) “Hiketeia.” JHS 93: 74-103.

Hansen, M.H. (1974) The Sovereignty of the People's Court in Athens in the Fourth Century B.C. and the Impeachment of Generals and Politicians (Odense: Odense University Press).

Hansen, M.H. (1975) The Sovereignty of the People's Court in Athens in the Fourth Century B.C. and the Public Action against Unconstitutional Proposals (Odense: Odense University Press).

Hansen, M.H. (1978) "Nomos and Psêphisma in Fourth-Century Athens." GRBS 19.4: 315-330.

Hansen, M.H. (1989) The Athenian Ecclesia I: A Collection of Articles 197683 (Copenhagen: Museum Tuculanums Forlag).

Hansen, M.H. (1991) The Athenian Democracy in the Age of Demosthenes (Oxford: Blackwell). 
Hansen, M.H. (2004) "The Ancient Athenian and the Modern Views of Liberty as a Democratic Ideal," in E. Robinson ed. Ancient Greek Democracy: Readings and Sources (Oxford: Blackwell Publishing).

Harris, E. M. (1989) “Demosthenes' Speech Against Meidias.” HSCP 92: 11736.

Harris, E.M. (1992) "Pericles' Praise of Athenian Democracy." HSCP 94: $157-67$.

Harris, E.M. (2000) “Open Texture” Dikê 3: 27-79.

Hart, H. L. A. (1961) The Concept of Law (Oxford: Clarendon Press, 2ed.).

Harvey, D. (1990) "The Sykophant and Sykophancy: Vexatious Redefinition?" in P. Cartledge, P. Millett, \& S. Todd eds. Nomos: Essays in Athenian Law, Politics, and Society (Cambridge: Cambridge University Press): 103-22.

Holland, L.B. (1941) “Axones.” AJA 45.3: 346-62.

Humphreys, S.C. (1988) "The Discourse of Law in Archaic and Classical Greece." Law and History Review 6.2: 465-93.

Johnstone (1999) Disputes and Democracy: The Consequences of Litigation in Ancient Athens (Austin: University of Texas Press).

Kraut, R. (2002) Founders of Modern Political and Social Thought: Aristotle (New York: Oxford University Press).

Lanni, A. (1997) "Spectator sport or serious politics? and the Athenian Lawcourts." JHS 117: 183-189. 
Lanni, A. (1999) "Precedent and Reasoning in Classical Athenian Courts: A Noble Lie?" The American Journal of Legal History 43: 27-51.

Lanni, A. (2004) “Arguing from 'Precedent': Modern Perspectives on Athenian Practice.” in E.M. Harris \& L. Rubenstein eds. The Law and the Courts in Ancient Greece (London: Duckworth): 159-72.

Lanni, A. (2006) Law and Justice in the Courts of Classical Athens (New York: Cambridge University Press).

Lintott, A. (1992) “Aristotle and Democracy.” CQ 42: 114-128.

Long, A.A. (2005) "Law and Nature in Greek Thought," in M. Gagarin \& D. Cohen, eds. The Cambridge Companion to Ancient Greek Law (Cambridge: Cambridge University Press): 412-30.

Longrigg, J. (1993) Greek Rational Medicine: Philosophy and Medicine from Alcmaeon to the Alexandrians (London: Routledge).

Low, P. (2007) Interstate Relations in Classical Greece: Morality and Power (Cambridge: Cambridge University Press).

MacDowell, D.M. (1975) "Law-Making at Athens in the Fourth Century B.C." JHS 95: 62-74.

MacDowell, D.M. (1978) The Law in Classical Athens (New York: Cornell University Press).

Maine, H. (1861) Ancient Law (London: Murray).

Markle, M.M. (2004) "Jury Pay and Assembly Pay at Athens," in P.J. Rhodes ed. Athenian Democracy (Edinburgh: Edinburgh University Press). 
Moore (1986) Aristotle and Xenophon on Democracy and Oligarchy (California: University of California Press).

Morris, I. (1996) "The Strong Principle of Equality and the Archaic Origins of Greek Democracy," in J. Ober \& C. Hedrick: 19-48.

Nightingale, A.W. (2007) "The Philosophers in Archaic Greek Culture," in H.A. Shapiro ed. The Cambridge Companion Archaic Greece (Cambridge: Cambridge University Press).

Ober, J. (1989) Mass and Elite in Democratic Athens (Princeton: Princeton University Press).

Ober, J. (1996) The Athenian Revolution (Princeton: Princeton University Press).

Ober, J. and C. Hedrick eds. (1996) Dêmokratia: A Conversation on Democracies, Ancient and Modern (Princeton: Princeton University Press).

Ober, J. (1998) Political Dissent in Democratic Athens: Intellectual Critics of Popular Rule (Princeton: Princeton University Press).

Osborne, R. (1985) "Law in Action in Classical Athens." JHS, 55: 40-58.

Osborne, R. (1990) "Vexatious Litigation in Classical Athens: Sykophancy and the Sykophant," in P. Cartledge, P. Millett, \& S. Todd eds. Nomos: Essays in Athenian Law, Politics, and Society (Cambridge: Cambridge University Press): 83-102.

Ostwald (1969) Nomos and the Beginnings of the Athenian Democracy (Oxford: Clarendon Press). 
Ostwald, M. (1986) From Popular Sovereignty to the Sovereignty of Law (Berkeley: University of California Press).

Ostwald, M. (1995) "Public Expense: Whose Obligation? Athens 600-454 B.C.E." TAPA 139.4: 368-79.

Ostwald (1996) "Shares and Rights: 'Citizenship' Greek Style and American Style," in J. Ober \& C. Hedrick: 49-62.

Quillin, L.M. (2002) “Achieving Amnesty: The Role of Events, Institution, and Ideas." TAPA 132: 71-107.

Raaflaub, K.A. (1996) "Equalities and Inequalities in Athenian Democracy" in J. Ober \& C. Hedrick: 139-74.

Raaflaub, K.A. (2004) The Discovery of Freedom in Ancient Greece (Chicago: University of Chicago Press, Rev. ed.).

Rhodes, P.J. (1972) The Athenian Boule (Oxford: Clarendon Press).

Rhodes, P.J. (1980) “Athenian Democracy After 403 B.C.” CJ 75.4: 305-323.

Rhodes, P.J. (1984) “Nomothesia in Fourth-Century Athens.” CQ 35.1: 55-60.

Rhodes, P.J. (1991) “The Athenian Code of Laws, 410-399 B.C." JHS 111: $87-100$.

Rihil, T.E. (1995) "Democracy Denied: Why Ephialtes Attacked the Areiopagus." JHS 115: 87-98.

Roberts, J.T. (1982) Accountability in Athenian Government (Wisconsin: University of Wisconsin Press).

Robertson, N. (1990) "The Laws of Athens, 410-399 BC: The Evidence for Review and Publication." JHS 110: 43-75. 
Rosenbloom, D.S. (2001) "A Commentary to Pseudo [Andokides] 4" Unpublished Manuscript.

Rosenbloom, D.S. (2004a) "Ponêroi vs. Chrêstoi: The Ostracism of Hyperbolos and the Struggle for Hegemony in Athens after the death of Perikles, Part 1." TAPA 134: 55-105.

Rubinstein, L. (2000) Litigation and Cooperation: Supporting speakers in the courts of classical Athens (Weisbaden: Historia Einzelschriften).

Sealey, R. (1982) “On the Athenian Concept of Law.” CJ 77.4: 289-302.

Simester, A.P. \& W.J. Brookbanks (2002) Principles of Criminal Law (Wellington: Brookers).

Sinclair, R.K. (1988) Democracy and Participation in Athens (Cambridge: Cambridge University Press).

Smith, S.B. (1925) "The Establishment of the Public Courts at Athens." TAPA 56: $106-119$.

Stockton, D. (1990) The Classical Athenian Democracy (New York: Oxford University Press).

Strauss, B.S. (1993) Fathers and Sons in Athens: Ideology and Society in the Era of the Peloponnesian War (Princeton: Princeton University Press).

Stroud, R. (1979) The Axones and Kyrbeis of Drakon and Solon (Berkeley: University of California Press)

Tarbell, F.B. (1889) "The Relation of Psêphismata to Nomoi at Athens in the Fifth and Fourth Centuries B.C.” AJP 10: 79-83. 
Todd, S.C. (1990) “Lady Chatterley's Lover and the Attic Orators: The Social Composition of the Athenian Jury.” JHS 110: 146-73.

Todd, S.C. (1993) The Shape of Athenian Law (Oxford: Clarendon Press).

Wilson, P.J. (1991) "Demosthenes 21 (Against Meidias): Democratic Abuse." PCPS 37: 164-95.

Winkler, J.J. (1990) The Constraints of Desire (New York: Routledge).

Wohl, V. (2002) Love Among the Ruins: The Erotics of Democracy in classical Athens (Princeton: Princeton University Press).

Wolpert, A.O. (2002) "Lysias 18 and Athenian Memory of Civil War." TAPA 132: $109-26$.

Wolpert, A.O. (2003) "Addresses to the Jury in Attic Orators." AJP 124: 537555. 